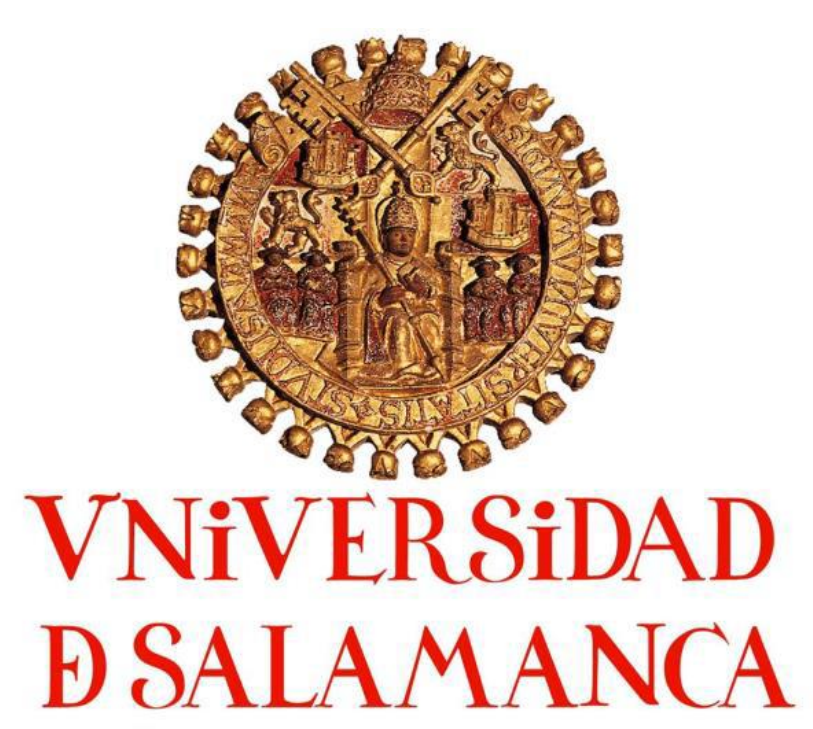

FACULTAD DE FARMACIA

DEPARTAMIENTO DE QUÍMICA ANALÍTICA, NUTRICIÓN Y

BROMATOLOGÍA

\begin{abstract}
Stevia rebaudiana Bertoni cultivated in the field and obtained by in vitro micropropagation: A prospective study of the antioxidant potential in different culture and storage conditions
\end{abstract}

DOCTORAL THESIS

Marisa Ramos Barroso

Supervisors:

Dra. Isabel Cristina Fernandes Rodrigues Ferreira

Dr. Celestino Santos-Buelga

Dra. Maria João Sousa

Salamanca, 2019 
To my son...since 2001 making me stronger... 
"Nothing in life is to be feared, it is only to be understood.

Now is the time to understand more, so that we may fear less."

Marie Curie 


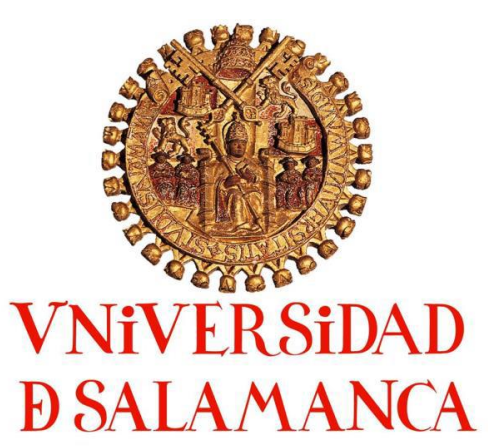

DPTO QUIMICA ANALÍTICA, NUTRICIÓN

Y BROMATOLOGÍA

FACULTAD DE FARMACIA

Campus Miguel de Unamuno-37007 Salamanca

Teléf.: 923294537 - Fax: 923294515

e-mail: nutr@usal.es

Celestino Santos Buelga, Catedrático de Nutrición y Bromatología de la Universidad de Salamanca, Isabel Cristina Fernandes Rodrigues Ferreira, Profesora Coordinadora Principal del Instituto Politécnico de Bragança (Portugal), y María João Sousa, Profesora Adjunta del mismo Instituto, directores del trabajo "Stevia rebaudiana Bertoni cultivated in the field and obtained by in vitro micropropagation: A prospective study of the antioxidant potential in different culture and storage conditions", realizado por Marisa Ramos Barroso para optar al grado de Doctor, AUTORIZAN la presentación del mismo al considerar que se han alcanzado los objetivos inicialmente previstos.

Salamanca, 18 de junio de 2019

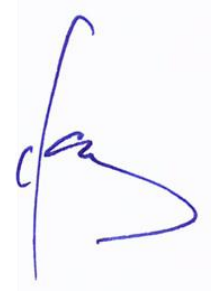

$$
\text { Jabled C.F.R. Fouviza }
$$

Celestino Santos-Buelga

Isabel C. F. R. Ferreira

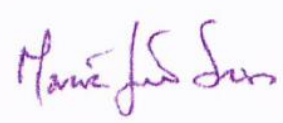

Maria João Sousa 
The studies developed within this $\mathrm{PhD}$ thesis led to the following articles (copies of which are included as annexes in the present memory), oral communications in scientific conferences and poster communications:

\section{Published articles:}

[1] Marisa Barroso, Lillian Barros, M. Ângelo Rodrigues, Maria João Sousa, Celestino Santos-Buelga, Isabel C.F.R. Ferreira. Stevia rebaudiana Bertoni cultivated in Portugal: A prospective study of its antioxidant potential in different storage conditions. Industrial Crops and Products, 90; 49-55. 2016.

[2] Marisa R. Barroso, Natália Martins, Lillian Barros, Amilcar Antonio, M. Ângelo Rodrigues, Maria João Sousa, Celestino Santos-Buelga, Isabel C.F.R. Ferreira. Assessment of the nitrogen fertilization effect on bioactive compounds of frozen fresh and dried samples of Stevia rebaudiana Bertoni. Food Chemistry, 243; 208-213. 2018.

\section{In process:}

[3] Marisa R. Barroso, Natália Martins, Lillian Barros, M. Beatriz P.P. Oliveira, M. Ângelo Rodrigues, Maria João Sousa, Celestino Santos-Buelga, Isabel C.F.R. Ferreira. Stevia rebaudiana Bertoni obtained by in vitro culture with kinetin: focus on chemical composition and antioxidant compounds. Submitted to Molecules. 2019.

\section{Oral communications in scientific conferences:}

[1] Barroso M., Barros L., Rodrigues M. Â, Sousa M. J., Santos-Buelga C., Ferreira I. Antioxidant profile of Stevia rebaudiana Bertoni cultivated in Portugal and submitted to different conservation conditions. 1st European Conference of Post graduate Horticulture Scientists. Palermo - Italy. May 12-13, 2016.

\section{Poster communications:}

[1] Marisa R. Barroso, Lillian Barros, M. Ângelo Rodrigues, Maria João Sousa, Celestino Santos-Buelga, Isabel C.F.R. Ferreira. Antioxidant potential of Stevia rebaudiana Bertoni cultivated in Portugal and conserved in different thermal conditions. XXII Encontro LusoGalego de Química, Polytechnic Institute of Bragança, Portugal, November 9-11, 2016.

[2] Marisa Barroso, Lillian Barros, Manuel Ângelo Rodrigues, Maria João Sousa, Isabel C.F.R. Ferreira. Stevia rebaudiana Bertoni cultivated in Portugal: A prospective study of its 
antioxidant potential in different storage conditions. I Congresso Nacional das Escolas Superiores Agrárias. Polytechnic Institute of Bragança, Portugal, 2-3, December, 2015.

[3] Marisa R. Barroso, Margarida Arrobas, Manuel Ângelo Rodrigues, M. João Sousa. "In vitro culture and acclimation process of Stevia rebaudiana". 6th World Congress on Stevia Tasteful 2014, Berlin, Germany, June 19-20, 2014. 


\section{ACKNOWLEDGMENTS}

This work would not be possible without the support of several people.

I would like to thank to my $\mathrm{PhD}$ supervisor Dr. Isabel Ferreira:

It has been for me an honour and a privilege working with a leader of excellence. Your tireless energy and success inspire every modern woman. "Thank you very much" becomes too insignificant to acknowledge you.

My PhD supervisor Dr. Celestino Santos-Buelga for his scientific support that was extremely important. Thank you very much!

My PhD supervisor Dr. Maria João Sousa for her friendship. Thank you very much!

Dr. Manuel Ângelo Rodrigues for his scientific contribution and support in the experiment development. Thank you very much!

Dr. Lillian Barros, thank you very much for your precious help!

My colleagues, who in one way or another, gave me their contributions.

My friends, they know how specials they are.

All my family, especially my parents and my son who are the reason for my strength, and my boyfriend for never letting me give up. 


\section{INDEX}

ACKNOWLEDGMENTS

INDEX

XIII

ÍNDICE XV

ABBREVIATIONS XVII

INDEX FIGURES XIX

INDEX TABLES XXI

INDEX EQUATIONS XXII

RESUMEN XXIII

ABSTRACT XXV

1. INTRODUCTION 3

1.1. Stevia rebaudiana Bertoni 3

1.2. Conservation processes 8

1.3. Fertilization to improve bioactive compounds production 9

1.4. Phytohormones to improve in vitro production of bioactive compounds 10

1.5. Objectives 12

2. MATERIALS AND METHODS 15

2.1. Plant samples 15

2.2. Cultivation procedure 16

2.3. In vitro micropropagation 17

2.4. Collection and treatment of the samples 18

2.5. Standards and reagents 18

2.6. Free sugars 19

2.7. Tocopherols 20

2.8. Extracts preparation 21

2.9. Evaluation of in vitro antioxidant properties 22

2.9.1 Scavenging effects on DPPH radicals . 22

2.9.2. Reducing power. 23 
2.10. Analysis of phenolic compounds

2.11. Statistical analysis __ 26

3. RESULTS AND DISCUSSION ___ 29

3.1. Stevia rebaudiana Bertoni cultivated in Portugal: A prospective study of its antioxidant potential in different conservation conditions ___ 29

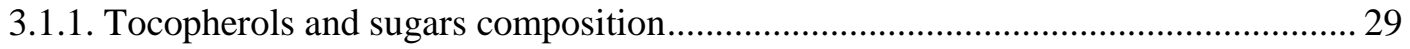

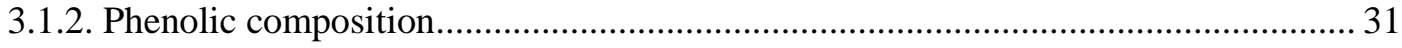

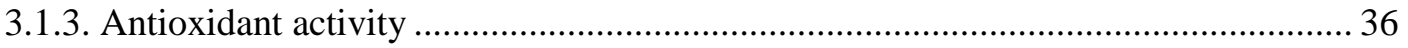

3.2. Assessment of the nitrogen fertilization effect on bioactive compounds of frozen fresh and dried samples of Stevia rebaudiana Bertoni______ 38

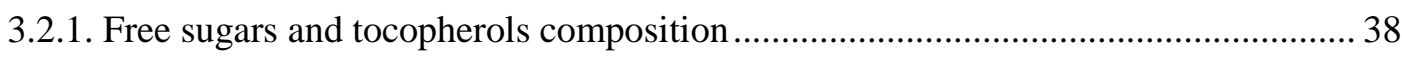

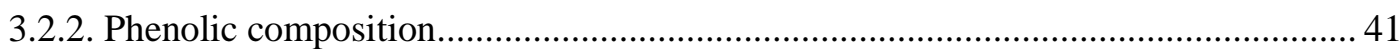

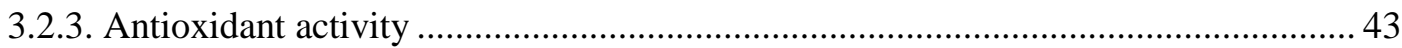

3.3. Stevia rebaudiana Bertoni obtained by in vitro culture with kinetin: focus on chemical composition and antioxidant compounds ___ 46

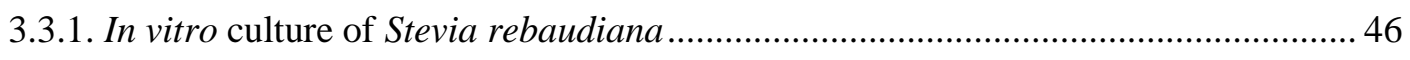

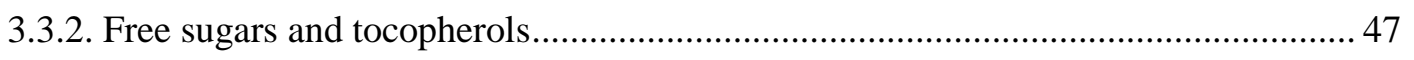

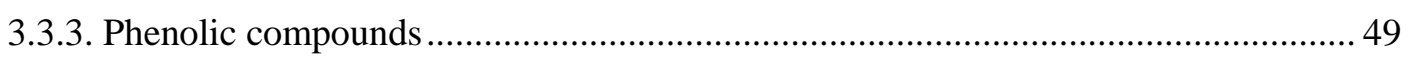

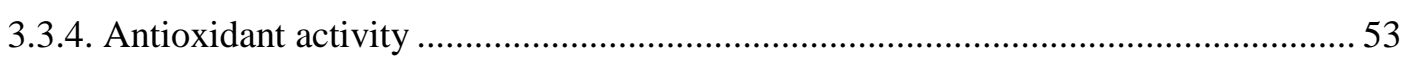

4. CONCLUSIONS ___ 57

RESUMEN__________________________ 61

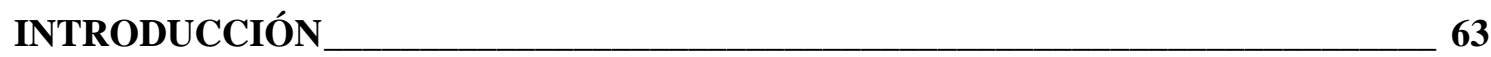

1.1. Stevia rebaudiana Bertoni ___ 63

1.2. Procesos de conservación____ 64

1.3. Fertilización para mejorar la producción de compuestos bioactivos ___ 65

1.4. Fitohormonas para mejorar la producción in vitro de compuestos bioactivos__ 66

OBJETIVOS _

PRINCIPALES RESULTADOS _ 69

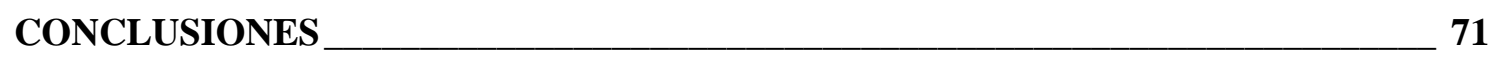

REFERENCES ___

ANNEXES ___ 87 


\section{ÍNDICE}

AGRADECIMIENTOS

XI

INDEX

XIII

ÍNDICE XV

ABREVIATURAS XVII

ÍNDICE FIGURAS XIX

ÍNDICE TABLAS XXI

ÍNDICE ECUACIONES XXII

RESUMEN XXIII

ABSTRACT XXV

1. INTRODUCCIÓN

1.1. Stevia rebaudiana Bertoni 3

1.2. Procesos de conservación 8

1.3. Fertilización para mejorar la producción de compuestos bioactivos 9

1.4. Fitohormonas en la producción in vitro de compuestos bioactivos 10

1.5. Objetivos 12

2. MATERIALES Y MÉTODOS 15

2.1. Muestras de plantas 15

2.2. Cultivo 16

2.3. Micropropagación in vitro 17

2.4. Colección y tratamiento de muestras 18

2.5. Patrones y reactivos 18

2.6. Determinación de azúcares libres 19

2.7. Determinación de tocoferoles 20

2.8. Preparación de extractos 21

2.9. Evaluación de propiedades antioxidantes in vitro 22

2.9.1 Ensayo de captación de radicales DPPH 22

2.9.2. Poder reductor 
2.10. Análisis de compuestos fenólicos __ 24

2.11. Análisis estadístico ___ 26

3. RESULTADOS Y DISCUSIÓN____ 29

Stevia rebaudiana Bertoni: Estudio prospectivo de su potencial antioxidante en diferentes condiciones de conservación___ 29

3.1.1. Composición de tocoferoles y azúcares...................................................................... 29

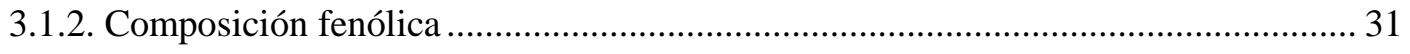

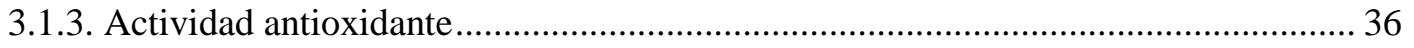

3.2. Evaluación del efecto de la fertlización con nitrógeno sobre compuestos bioactivos en muestras congeladas en fresco y desecadas de Stevia rebaudiana Bertoni____ 38

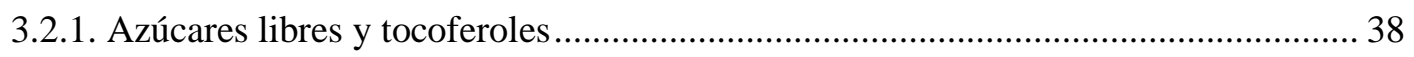

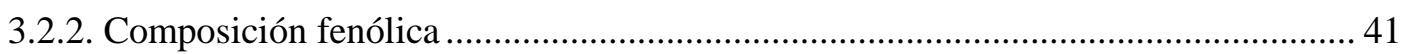

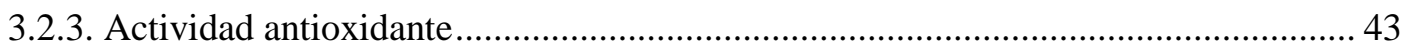

3.3. Stevia rebaudiana Bertoni obtenida por cultivo in vitro con cinetina: composición química y compuestos antioxidantes___ 46

3.3.1. Cultivo in vitro de hojas de Stevia rebaudiana ....................................................... 46

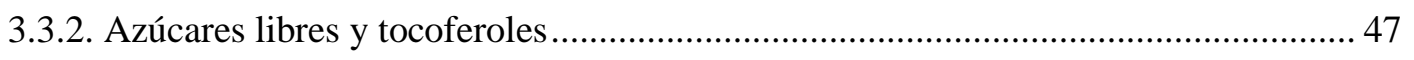

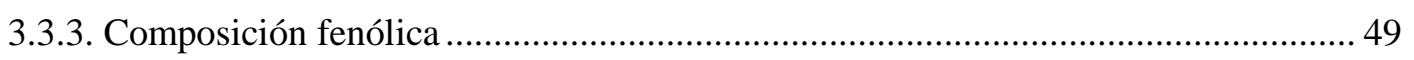

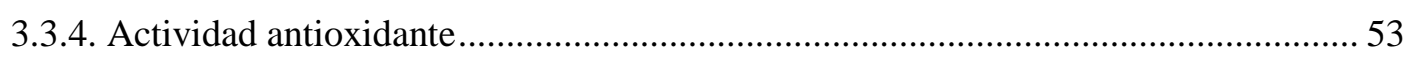

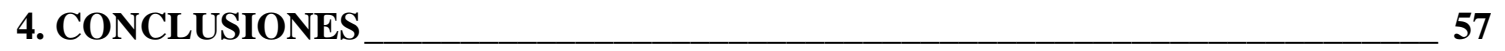

RESUMEN___ 61

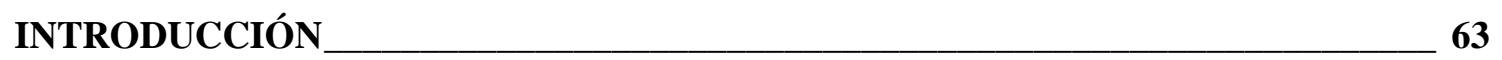

1.1. Stevia rebaudiana Bertoni ___ 63

1.2. Procesos de conservación___________________ 64

1.3. Fertilización para mejorar la producción de compuestos bioactivos ___ 65

1.4. Fitohormonas para mejorar la producción in vitro de compuestos bioactivos__ 66

OBJETIVOS —__ 67

PRINCIPALES RESULTADOS _ 69

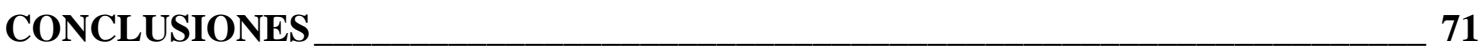

REFERENCIAS ___ 75

ANEXOS _ _ _ 87 


\section{ABBREVIATIONS}

ABS

Absorbance

ANOVA

Analysis of variance

BHT

Butylated hydroxytoluene

CES

Collision energy spread

DAD

Diode array detector

DNA

Deoxyribonucleic acid

DP

Declustering potential

DPPH

2,2-Diphenil-1-picrylhydrazyl

E-960

Additive (Steviol Glycosides)

$\mathrm{EC}_{50}$

Concentration with $50 \%$ of antioxidant activity

EP

Enhanced potential

EPI

Enhanced production

ESI

Electrospray Ionization

HPLC

High Performance Liquid Chromatography

IS

Internal standard

LOX

Lipoxygenase

$\min$

Minutes

MS

Mass spectrometer

nd

Not detected

RI

Refraction index

RP

Reducing power

RSA

Radical scavenging activity

Rt

Retention time 
SD

SGs

SPSS

$\mathrm{T}$

$\operatorname{Tmax}$

Tmin

UK

USA

UV

VIS

WHO

$\lambda \max$
Standard deviation

Steviol Glycosides

Statistic package for social sciences

Tons

Temperature maximum

Temperature minimum

United Kingdom

United States of America

Ultraviolet

Visible

World Health Organization

Wavelength of maximum absorption. 


\section{INDEX FIGURES}

Figure 1. Stevia rebaudiana Bert. (stevia). 3

Figure 2. Different stages of flower opening in S. rebaudiana. 4

Figure 3. Chemical structures of stevioside (1) and its hydrolysis products steviol (2) and isosteviol (3) 5

Figure 4. Main bioactive properties attributed to phenolic compounds. 6

Figure 5. Field trial supporting stevia cultivation. 15

Figure 6. Greenhouse with the cuttings of stevia previously rooted. 16

Figure 7. In vitro stevia micropropagation:. 17

Figure 8. Processing of stevia samples: left photo, frozen at $-20^{\circ} \mathrm{C}$; right photo, driedoven at $30^{\circ} \mathrm{C}$. 18

Figure 9. Depiction of the free sugar analysis. 19

Figure 10. Depiction of tocopherol analysis. 21

Figure 11. Overall procedure for extracts preparation. 21

Figure 12. Depiction of a DPPH scavenging activity assay with the strongest (more antioxidant) concentrations showing a yellow tone. 22

Figure 13. Reduction of the DPPH radical. 23

Figure 14. Multiwell plate showing samples prepared for measurement of the reducing power assay. The stronger the antioxidant concentrations the darker the Prussian blue tone. 24

Figure 15. Depiction of the phenolic compounds, filtration and injection. 25

Figure 16. HPLC chromatograms showing the phenolic compounds profile of ovendried Stevia rebaudiana leaves recorded at 370 (A) and 280 (B) $\mathrm{nm}$. 33

Figure 17. Plot of the percentages of scavenging activity of DPPH radicals in extracts

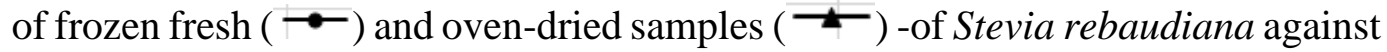
extract concentration. $\mathrm{EC}_{50}$ values (extract concentration corresponding to $50 \%$ of DPPH scavenging activity) of $50.66 \pm 3.64 \mu \mathrm{g} / \mathrm{mL}$, for frozen fresh samples, and $22.87 \pm 2.17 \mu \mathrm{g} / \mathrm{mL}$, for oven-dried samples.

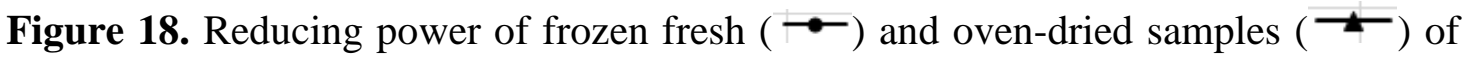
Stevia rebaudiana according to the extract concentration. Higher absorbance indicates higher reducing power. $\mathrm{EC}_{50}$ values (extract concentration giving 0.5 of absorbance) of $39.73 \pm 0.10 \mu \mathrm{g} / \mathrm{mL}$, for frozen fresh samples, and $82.79 \pm 0.09$ $\mu \mathrm{g} / \mathrm{mL}$, for oven-dried samples. 
Figure 19. In vitro cultured S. rebaudiana with kinetin (A) and without kinetin (B). 47

Figure 20. HPLC profiles of tocopherols (A) and free sugars (B) in S. rebaudiana leaves cultivated in vitro without (-) and with kinetin (---). (A) 1- $\alpha$-tocopherol, $2-\gamma-$ tocopherol, 3- $\delta$-tocopherol, 4- Tocol (IS); (B) 1-fructose, 2- glucose, 3- sucrose, 4- treahalose, 5- melezitose (IS), 6- raffinose.

Figure 21. HPLC phenolic profiles of S. rebaudiana leaves cultivated in vitro without kinetin (A) and with kinetin (B), recorded at $330 \mathrm{~nm}$. 51 


\section{INDEX TABLES}

Table 1. Composition of Stevia rebaudiana leaves in tocopherols and free sugars (mean $\pm \mathrm{SD})$.

Table 2. Phenolic compounds identification and quantification in Stevia rebaudiana leaves.

Table 3. Sugars contents (g/100 g dry weight) in Stevia rebaudiana Bertoni leaves, under different $\mathrm{N}$ substrate rates and process (frozen fresh and dried).

Table 4. Tocopherol contents (mg/100 g dry weight) in Stevia rebaudiana Bertoni leaves, under different $\mathrm{N}$ substrate rates and process (frozen fresh and dried).

Table 5. Contents of phenolic compounds (mg/g extract) in Stevia rebaudiana Bertoni leaves, under different $\mathrm{N}$ substrate rates and process (frozen fresh and dried).

Table 6. Antioxidant activity (expressed in $\mathrm{EC}_{50}$ values, $\mathrm{mg} / \mathrm{mL}$ ) of Stevia rebaudiana Bertoni leaves, under different $\mathrm{N}$ substrate rates and process (frozen fresh and dried).

Table 7. Correlation coefficients of phenolic compounds with in vitro antioxidant activity of Stevia rebaudiana Bertoni leaves, under different $\mathrm{N}$ substrate rates and process (frozen fresh and dried).

Table 8. Composition in tocopherols and free sugars of $S$. rebaudiana leaves cultivated in vitro $(\mathrm{n}=9$, mean $\pm \mathrm{SD})$.

Table 9. Phenolic compounds identification and quantification in S. rebaudiana leaves cultivated in vitro $(\mathrm{n}=9$, mean $\pm \mathrm{SD})$.

Table 10. Phenolic compounds identification and quantification in S. rebaudiana leaves cultivated in vitro $(\mathrm{n}=9$, mean $\pm \mathrm{SD})$. 


\section{INDEX EQUATIONS}

Equation 1. Formula used to calculate the percentage of DPPH discoloration formula.22

Equation 2. Two reaction pairs for the reducing power assay. 24 


\section{RESUMEN}

La realización de estudios con condiciones de cultivo bien establecidas es de extrema importancia para estandarizar la producción de plantas y, por lo tanto, su composición química. Sin embargo, las condiciones de conservación también pueden influir sobre los compuestos bioactivos presentes en la mismas. En el presente trabajo, muestras de Stevia rebaudiana Bertoni (estevia) cultivadas en el noreste de Portugal fueron sometidas a dos condiciones de conservación diferentes: secado en invernadero a $30{ }^{\circ} \mathrm{C}$ y congelación en fresco a $-20{ }^{\circ} \mathrm{C}$, y posteriormente almacenadas durante seis días. Por otra parte, para definir las mejores condiciones de cultivo y maximizar los niveles de compuestos bioactivos, se evaluó también el efecto de diferentes concentraciones de nitrógeno (N) sobre la composición química y las propiedades antioxidantes de las hojas frescas y secas congeladas de estevia. En todos los casos, las muestras fueron caracterizadas en cuanto a cuantificación e identificación de azúcares libres, tocoferoles y compuestos fenólicos, y determinación del potencial antioxidante mediante ensayos de captación del radical DPPH y poder reductor (RP) de sus extractos metanol:agua.

Los azúcares más abundantes en las muestras estudiadas fueron xilosa, arabinosa + fructosa y sacarosa, mientras que los principales compuestos fenólicos fueron los derivados del ácido cafeico, ácido 5-O-cafeoilquínico (ácido clorogénico) y ácido 3,5-O-dicafeoilquínico.

Las muestras secadas en invernadero dieron lugar a valores más elevados de actividad antioxidante y de compuestos fenólicos totales que las mantenidas a $-20^{\circ} \mathrm{C}$. Sin embargo, las muestras frescas congeladas presentaron contenidos más altos de tocoferoles y de azúcares totales. Se pudo comprobar que el proceso de conservación afectaba más significativamente los valores de tocoferoles y de contenido de azúcares que la fertilización con N. En general, la fertilización con N conducía a una mejora en la composición química y el potencial bioactivo de las hojas de estevia. Los mayores niveles de compuestos fenólicos se encontraron en las muestras secas y en aquellas fertilizadas con $25 \mathrm{~kg}$ de N/ha. Las hojas de plantas fertilizadas con 25 y $50 \mathrm{~kg} \mathrm{~N} / \mathrm{ha}$ también fueron las que evidenciaron mayor actividad antioxidante, que parecía estar especialmente determinada por la composición fenólica.

Los reguladores del crecimiento de las plantas, que controlan los procesos fisiológicos en células especializadas, se utilizan en el desarrollo de cultivos de plantas in vitro. Por ello, se estudió también la composición en azúcares libres, tocoferoles y compuestos fenólicos y el 
potencial antioxidante en hojas de estevia obtenidas por cultivo in vitro con y sin cinetina (fitorregulador). Las muestras cultivadas sin cinetina evidenciaron una mayor concentración de tocoferoles totales y de compuestos fenólicos que las obtenidas en presencia de cinetina. Por lo contrario, se observó una tendencia opuesta para los azúcares libres totales. Los extractos de metanol:agua obtenidos de muestras cultivadas sin cinetina también evidenciaron mayor actividad captadora de radicales y poder reductor que los de las muestras cultivadas en presencia de cinetina, lo que parece confirmar la relación de este fitorregulador con la producción de compuestos fenólicos. En general, el cultivo in vitro es una forma eficaz de obtener biomasa vegetal que pueda ser utilizada como fuente de compuestos antioxidantes de manera continua y sin estar sometida a condiciones edafoclimáticas. Sin embargo, a las dosis ensayadas el empleo de cinetina, aunque mejoró la tasa de multiplicación, no condujo a una mayor acumulación de moléculas bioactivas, por lo que se deberían ensayar otros niveles de aplicación de este regulador, así como otras hormonas para establecer su influencia sobre la producción de este tipo de compuestos.

El estudio realizado proporciona evidencias para elegir la metodología más apropiada para favorecer la acumulación y preservar los niveles de metabolitos primarios y secundarios de Stevia rebaudiana relacionados con su actividad antioxidante. 


\section{ABSTRACT}

Studies with well-established cultivation conditions are of utmost importance in order to standardize plants production and, therefore, its chemical composition. However, the conservation conditions may also have an influence on the bioactive compounds present in those plants. In the present work, Stevia rebaudiana Bertoni samples cultivated in the northeastern of Portugal were submitted to different conservation conditions (oven-dried at $30^{\circ} \mathrm{C}$, for six days, or kept fresh by freezing $\left(-20^{\circ} \mathrm{C}\right)$ in the same period).

Furthermore, in order to define the best growing conditions to maximize the levels of bioactive compounds, the effect of different nitrogen $(\mathrm{N})$ rates on the chemical composition and antioxidant properties of stevia frozen fresh and dried leaves was also evaluated. All samples were analysed for their content and composition in sugars, tocopherols and phenolic compounds, as well as the free radical scavenging activity (DPPH) and reducing power (RP) of their methanol:water extracts.

The most abundant sugars were xylose, arabinose + fructose and sucrose, whereas the main phenolic compounds in all samples were two caffeic acid derivatives, 5- $O$-caffeoylquinic acid (chlorogenic acid) and 3,5-O-dicaffeoylquinic acid.

Dried samples presented higher contents of antioxidant activity and total phenolic compounds than fresh frozen ones, whereas the highest values of total tocopherols and total sugars were registered in frozen samples. In general, processing affects more significantly tocopherol and sugar contents than $\mathrm{N}$ fertilization, although this latter provides an improvement in the chemical composition and bioactive potential of stevia leaves. Greater levels of phenolic compounds were found in dried samples and in those fertilized with $25 \mathrm{~kg}$ $\mathrm{N} / \mathrm{ha}$. Leaves from plants fertilized with 25 and $50 \mathrm{~kg} \mathrm{~N} / \mathrm{ha}$ were also those that evidenced the highest antioxidant activity, which seemed to be influenced by the phenolic composition.

Plant growth regulators are used in the development of in vitro plant cultures, controlling the physiological processes in specialized cells. Stevia leaves obtained by in vitro culture with and without kinetin (phytoregulator) were analyzed to compare their composition in free sugars, tocopherols and phenolic compounds, as also to assess the antioxidant activity of their methanol:water extracts. Samples cultured without kinetin evidenced higher concentration in total tocopherols and phenolic compounds than those obtained in the presence of kinetin. Otherwise, an opposite trend was observed for total free sugars. 
Methanol:water extracts obtained from samples cultured without kinetin also evidenced higher radical scavenging activity and reducing power than those cultured in the presence of kinetin, which seems to confirm the relationship between the antioxidant activity and the content of phenolic compounds. Overall, in vitro culture can be used as an efficient way to produce plant sources of antioxidant compounds, but other hormones besides kinetin should also be tested so as to check their ability to improve the production of bioactive molecules. This study gives clues to select the most appropriate methodology to enhance and preserve primary or secondary metabolites involved in the antioxidant activity of Stevia rebaudiana. 
INTRODUCTION 


\section{INTRODUCTION}

\subsection{Stevia rebaudiana Bertoni}

Stevia rebaudiana Bertoni (stevia) is an ancient perennial shrub, a member among 950 genera of the Asteraceae family which comprises approximately 50000 species of perennial herbs and shrubs (Soufi et al., 2016; Serfaty et al., 2013). It is an erect, tap root and perennial herbaceous species that reaches up to $90 \mathrm{~cm}$ in height, with small leaves that measure from 3 to $5 \mathrm{~cm}$ in length and 1 to $1.5 \mathrm{~cm}$ in width, being simple and sessile on opposite and alternate vertices (Figure 1).

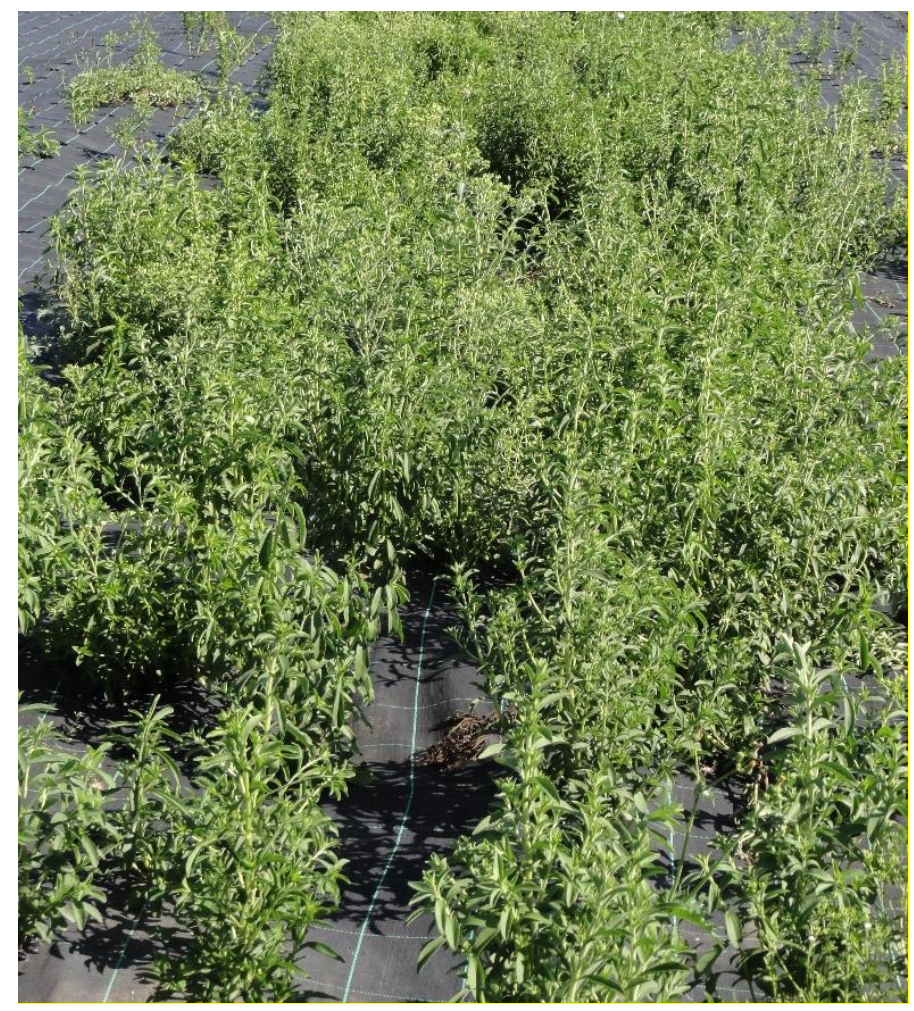

Figure 1. Stevia rebaudiana Bert. (stevia) (Author: Manuel Ângelo Rodrigues).

The flowers are white and the petals are grouped in terminal or axillary racemes (Figure 2). They grow mostly in altitudes of 500-3000 $\mathrm{m}$ in semidry mountain areas, but they can also grow in grasslands, scrub forests, and sub-alpine areas. Their fruits are five-ribbed spindleshaped achenes (Magalhães et al., 2000; Serfaty et al., 2013). 


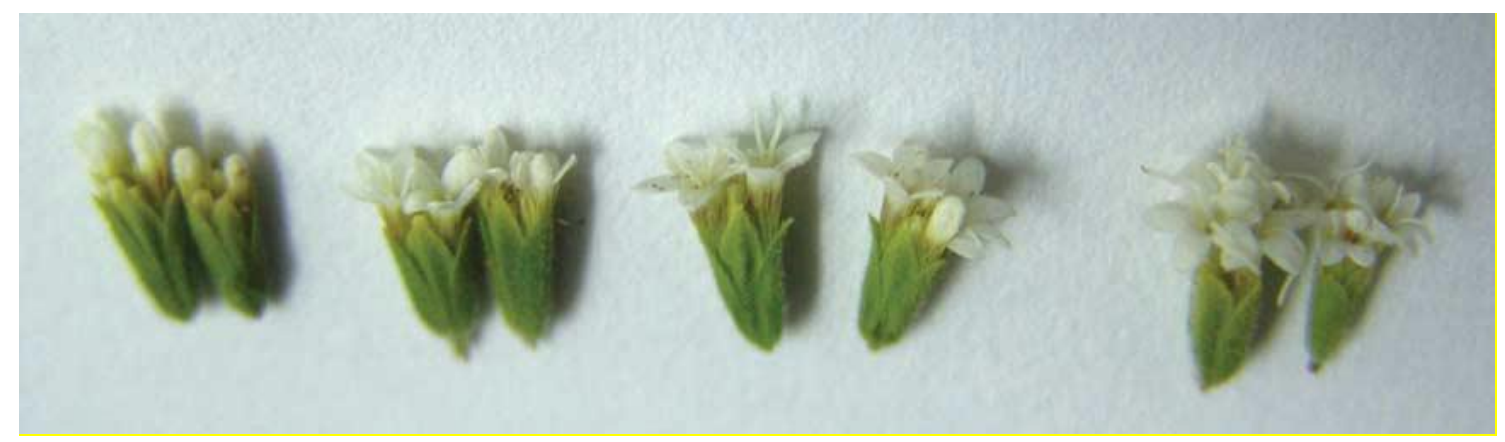

Figure 2. Different stages of flower opening in S. rebaudiana (Yadav et al., 2010).

It is a plant native from the Amambay region in the northeast of Paraguay and the neighbouring areas of Brazil and Argentina. Dry leaves have been used for centuries by the indigenous Guarani Indians of South America as a traditional sweetener, who call it $k a$ 'a $h e^{\prime} \hat{e}$ ("sweet herb"). Stevia is known as the sweet herb of Paraguay, sweet leaf, candy leaf, and honey leaf (Magalhães et al., 2000; Serfaty et al., 2013; Reis et al., 2017).

Recognized by its sweetener properties, stevia is an emerging economical species throughout the world (Khalil et al., 2016). China is the largest stevia grower in the world, but stevia is also cultivated in other places, as Japan, Taiwan, Thailand, Korea, Brazil, Malaysia, Paraguay and some countries of the European Union. Japan and Korea are the largest markets for stevia (Yadav et al., 2010).

Stevioside $\left(\mathrm{C}_{38} \mathrm{H}_{60} \mathrm{O}_{18}\right)$, a diterpenoid compound, is the principal sweetener produced by stevia (Figure 3). Japan was the first country in Asia to commercialize it as a sweetener for food and drug industries (Pal et al., 2015; Bender, 2018). In the international markets stevia derived sweeteners are commonly commercialized in the form of liquid extracts or as stevioside crystals. (Bender, 2018). Nevertheless, stevia has been used commercially since the 1970s, when the Japanese developed processes to extract and refine stevioside from the leaves (Dacome et al., 2005). 

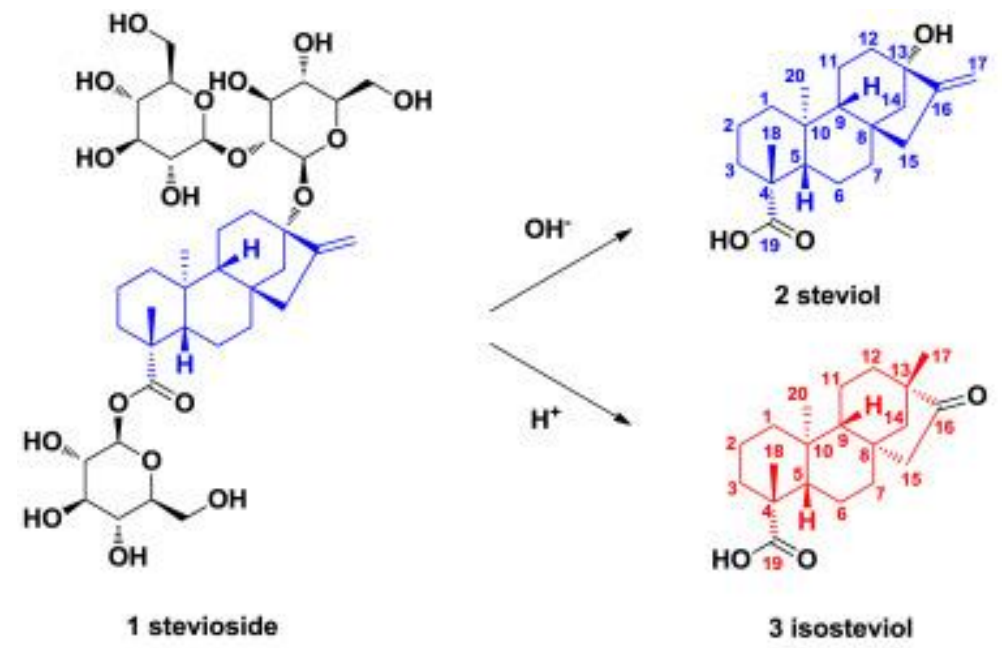

Figure 3. Chemical structures of stevioside (1) and its hydrolysis products steviol (2) and isosteviol (3) (Wang et al. 2018).

Their derived end-products have been used for various purposes in the past. However, this shrub has gained an important economic value and scientific interest, due to the presence of a high concentration of natural, dietetically valuable sweeteners in the leaves. Stevia is widely known for the sweet-tasting and low-calorie diterpenoid steviol glycosides (SGs) content in its leaves, which can reach up to $30 \%$ of the leaf dry weight (Geuns et al., 2003). SGs are secondary metabolites, specifically tetracyclic diterpene glucosides (Soufi et al., 2016), that can be 300 times sweeter than sucrose (Gardana et al., 2010) and with the advantages of not being caloric and avoiding high levels of blood sugar (Periche et al., 2015).

The demand for natural sweeteners has been gaining more and more importance due to the great controversy associated with the use of some synthetic sweeteners as cyclamate, aspartame or acesulfame-K. SGs, as non-caloric natural sweeteners, have been widely used in soft drinks, soy sauce, instant noodles, yogurt and other foods in Japan, Brazil and elsewhere. The European Food Safety Authority has recognized the safety of the stevia leaf extract for alimentary use since 2011 (Yu et al., 2017). Currently they are recognized as food additives in the European Union (E-960).

In addition, the extracts from stevia contain other metabolites with bioactive potential, such as alkaloids, water-soluble chlorophyll proteins, xanthophylls, hydroxycynnamoyl derivatives (caffeoyl and chlorogenic acid derivatives), neutral water-soluble oligosaccharides, free sugars, amino acids, lipids, essential oils and trace elements (Komissarenko et al., 1994). They have also been shown to possess antimicrobial and antioxidant activities (Xi et al., 1998; Tadhani et al., 2007). Hence, the antioxidant 
properties of stevia and its steviol glycosides are an attractive argument for producers and consumers (Bender, 2018).

In vitro antioxidant activity and preventive activity against DNA oxidative damage were reported for crude methanolic and ethyl acetate extracts from S. rebaudiana leaves (Ghanta et al., 2007). Previous studies have shown that stevia leaves contain different antioxidant compounds, such as ascorbic acid (Kim et al., 2011), phenolic compounds (Shukla et al., 2009) including flavonoids (Jahan et al., 2010; Abou-Arab and Abu-Salem 2010) and tannins (Savita et al., 2004).

Phenolic compounds are secondary metabolites of higher plants synthesized for a variety of roles in plant life, including natural resistance against biotic and abiotic stress, herbivory defence and cell-to-cell signalling, thus increasing plant competitiveness. These compounds are important because of their role as antioxidants, being related in the prevention against oxidative damage diseases, such as coronary heart disease (Robbins et al., 2005). Other bioactive properties have been reported (Figure 4), such as anticariogenic, antineoplastic, antihypertensive, anti-inflammatory and antihyperglycemic activities (Yang et al., 2015).

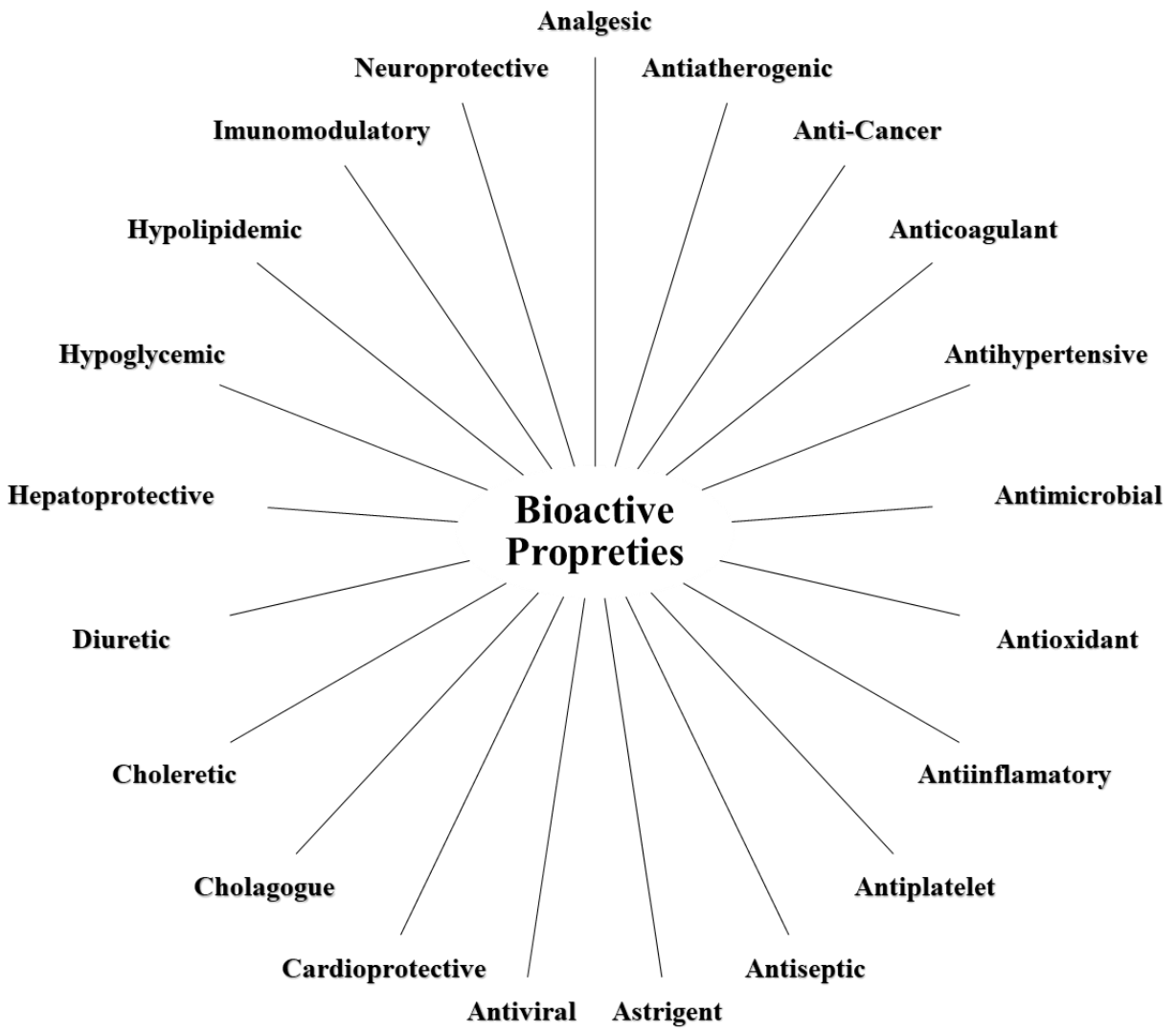

Figure 4. Main bioactive properties attributed to phenolic compounds (Ferreira et al., 2017). 
The analysis of phenolic components is complicated by the large variety of natural derivatives (estimated to be higher than 8,000), and because they are minor components in a complex plant matrix.

Flavonoids are the largest and the most studied group of plant phenols with significant bioactivity. Flavonoids mostly occur in leaves and skin of fruits, displaying numerous benefits to the plants. They usually occur combined with sugars, being commonly distinguished six main different subclasses of flavonoids: anthocyanins, flavanols, flavanones, flavones, flavonols, and isoflavones (Ferreira et al., 2017). To varying degrees, these compounds show potent antioxidant and antiradical activities in vitro, scavenging $\mathrm{O} 2^{\circ-}$ , $\mathrm{OH}^{\circ}$, and $\mathrm{ROO}^{\circ}$ (Van Acker et al., 1996). Some flavonoids, such as flavones and flavonols are also used in cosmetic formulations due to their anti-ageing properties and therapeutic potential against skin inflammation (Gawel-Beben et al., 2015). Stevia leaves are increasingly consumed as infusions due to their antioxidant properties, which are related to their high levels of flavonoids and other phenolic compounds (Periche et al., 2015).

The content of a broad range of biologically active substances makes Stevia rebaudiana a valuable ingredient not only for food products but also for cosmetics and cosmeceuticals (Gawel-Beben et al., 2015). Cosmetics have a deep relation to natural products. It is true that there are many cosmetic products that have catchphrases or selling points claiming $100 \%$ pure natural ingredients; however, it is impossible to make cosmetics without natural products, regardless of such catchphrases. Hence, as regards natural products, no one is in doubt about the notion that they are something that cannot be done away with in cosmetics (Ota \& Yokohama 2010).

Stevia was included in a compendium of natural products, approved as cosmetic ingredients in the official book compiled by the Ministry of Health, Labour and Welfare of Japan before the flexible regulation of 2001 (Ota \& Yokoyama 2010). Nowadays, several cosmetics with the active ingredient of Stevia rebaudiana as antioxidant are used as anti-aging. For its common use within a wide range of applications, the worldwide production of $S$. rebaudiana leaf has risen to an estimated $4000 \mathrm{t}$ annually (Yu et al., 2017). However, it is important to evaluate if the chemical composition of the plant is affected by the conservation and cultivation processes. 


\subsection{Conservation processes}

Drying process is the oldest way to preserve leaves. This classical method of food preservation serves lighter weight for transportation and small space for storage, which prevents microorganisms' growth and avoids certain biochemical reactions that may alter and depreciate the product (Babu et al., 2018; Navale et al., 2014). Plants with commercial value are often stored for some time before use and an efficient conservation is very important to avoid the loss of bioactive molecules during this process (Pinela et al., 2011).

Leaves normally lose up to $85 \%$ of their weight on the drying procedure. Also, during this process, several low boiling component losses and oxidation changes may take place that affect nutritional, physical and chemical composition of dried leaves, and subsequently quality attributes like texture, color, flavor and nutritional value (Babu et al. 2018; AhmadQasem et al., 2013). The drawback undoubtedly lies in the losses of nutritive constituents such as thermo-labile vitamins during high temperature thermal processing (Korus et al., 2011). Moreover, due to their low water content, dried leaves are generally assumed to have active nutrient levels three to four times higher than fresh leaves (Babu et al., 2018).

Food freezing is another efficient and adequate preservation and storage method used to preserve plant raw materials both in the food industry and in households, including preserve the quality of medicinal plants although the cost is higher than hot air drying (Periche et al., 2015; Korus et al., 2011). The low temperatures commonly used for frozen foods can help maintain initial quality and nutritive value practically unchanged. Freezing is also considered to be a safe method of preserving bioactive compounds. Nonetheless, whereas Mullen et al. (2002) found that phenolic compounds of Rubus idaeus L. fruit were not affected by freezing Ahmad-Qasem et al. (2013) reported results in drying olive leaf extracts with a significant $(\mathrm{p}<0.05)$ influence on the antioxidant potential, and both drying and freezing methods significantly $(\mathrm{p}<0.05)$ influenced the concentration of the main polyphenols identified. Clearly, there is a great discrepancy about the retention of active compounds in herbal teas and their further extraction according to the different drying techniques applied (Periche et al., 2015).

In general, vacuum freeze drying has been considered the best method for water removal, giving rise to dried products of higher quality Lin et al. (2011) described higher antioxidant capacity and total phenolic values when the leaves of Echinacea purpurea were freeze dried than when they were dehydrated with hot air. Pinela et al. (2011) also obtained larger 
amounts of antioxidants when leaves of the Genista sp. were freeze dried in comparison with shade drying. However, despite its many advantages, freeze drying has also some drawbacks, e.g., it is recognized as the most expensive process for manufacturing a dehydrated product and it requires a previous freezing that, in certain ways, might also affect quality (Ahmad-Qasem et al., 2013).

\subsection{Fertilization to improve bioactive compounds production}

Many functional properties of foods are based on the actions of specific bioactive components; phytochemicals in plant foods are especially important (Robbins et al., 2005). The concentration of plant secondary metabolites was found to be influenced by environmental conditions such as light intensity, carbon dioxide levels, temperature, fertilization or biotic and abiotic factors, which can change the concentration of these active constituents (Ibrahim et al., 2011).

There is a lack of information about the real effects of fertilization on chemical and bioactive properties of $S$. rebaudiana. It is known that chemical and biological diversity of stevia plants are influenced by several factors like genotype, phenological stage and growth conditions (Brandle \& Rosa, 1992; Brandle et al., 1998; Yadav et al., 2010). In fact, nitrogen $(\mathrm{N})$, phosphorous $(\mathrm{P})$ and potassium $(\mathrm{K})$ fertilization, as well as plant status play an important role in defining the final concentration of secondary metabolites and, therefore, biological potential (Aires et al., 2006). Among them, $\mathrm{N}$ is conceived as one of the most important essential elements in plant science, being used by plants to synthesize many organic compounds, such as amino acids, proteins, enzymes, and nucleic acids (Koeduka et al., 2006). Beyond this, $\mathrm{N}$ also has other functions in plant life, such as those related with biomass yield (Rodrigues et al., 2016); presently, it was confirmed that high rates of $\mathrm{N}$ increase both the number and size of leaf cells (Yadav et al., 2010).

Regarding bioactive constituents, and despite the existence of conflicting results, it has been shown that $\mathrm{N}$ availability not only influences the secondary metabolites production in a predictable manner, but also plant growth and differentiation processes (Aires et al., 2006; Ibrahim et al., 2011). Thus, it becomes increasingly evident that different $\mathrm{N}$ rates have influence in the biosynthesis of active constituents by cultivated medicinal plants (Karimi et al., 2013; Tavarini et al., 2015). For example, Tavarini et al. (2015) observed that both $\mathrm{N}$ fertilization and harvest time exert a pronounced influence on phytochemical composition 
and antioxidant activity of stevia. A similar scenario was also observed in Labisia pumila (Benth. \& Hook), indicating that handling of $\mathrm{N}$ fertilization levels may be an effective method to improve the expression of secondary metabolites (Ibrahim et al., 2011). Otherwise, other studies described contrary results of $\mathrm{N}$ utilisation, with increasing levels supplying a negative effect on the biosynthesis of flavonoids and chlorogenic acid in plants, as found by Awad \& de Jager (2002) in apple skin. Similarly, Patil \& Alva (1999) observed that the concentration of the flavonoids naringin and rutinoside decreased in the fruit with increased N supply in grapefruit, whereas Bongue \& Phillips (1995) reported that nitrogen (N) deficit increased the level of total flavonoids by $14 \%$ in tomato.

While $\mathrm{N}$ is an essential nutrient element for crop growth and quality, little is known about the effect of its supply on the antioxidant activity of medicinal plants (Ibrahim et al., 2012). However, in general, research is overlooking the fact that the availability of $\mathrm{N}$ might be a determinant/important factor on secondary metabolism in medicinal and aromatic plants.

\subsection{Phytohormones to improve in vitro production of bioactive compounds}

World Health Organization (WHO) estimates that $80 \%$ of world population still depends on traditional medicines to obtain primarily basic health care. Indeed, two thirds of the existing anti-carcinogenic and anti-infectious drugs in the market derives from plants. In addition, with the unceasing market demand for natural products, an environmental concern emerges relatively to the loss of plant populations, genetic diversity, habitat degradation and, even, species extinction (Dias et al., 2016).

The technique of plant tissue culture is used for growing isolated plant cells, tissues and organs under axenic conditions (in vitro) to regenerate and propagate entire plants. 'Tissue culture' is commonly used as a blanket term to describe all types of plant cultures, namely callus, cell, protoplast, anther, meristem, embryo and organ cultures. The different techniques of culturing plant tissues may offer certain advantages over traditional methods of propagation. Growing plants in vitro in a controlled environment, with in-depth knowledge of the culture conditions and the nature of the plant material, ensures effective clonal propagation of genetically superior genotypes of economically important plants (Iliev et al., 2010). 
Successful in vitro propagation of plants is now being used for commercialization. Many commercial laboratories and national institutes worldwide use in vitro culture system for rapid plant multiplication, germplasm conservation, elimination of pathogens, genetic manipulations, and to produce secondary metabolites that are used as pharmaceuticals, flavors, fragrances, coloring agents, food additives, and agrochemicals (Wang et al., 2017; Kumar \& Reddy, 2011). In fact, the search for plant growth regulators, also known as phytohormones, has revolutionized the development of in vitro plants culture, by allowing to control physiological processes of more specialized cells, and even through inducing secondary metabolites production (Dias et al., 2016).

Micropropagation is essentially established nowadays and could overcome the genetic segregation of the plants germinating from seeds; field-selected elite strains could be efficiently propagated with micropropagation techniques. Micropropagation techniques are of three types based on the way of propagation: first, the propagation from shoots with cytokinins like benzyladenine or kinetin; second, multiple shoot differentiation from dedifferentiating tissue, callus, with an auxin like indole acetic acid; and finally, the embryo differentiation from callus. The two methods need the rooting process with an auxin like indole acetic acid and with naphthaleneacetic acid thereafter. Nowadays, the method of propagation from shoots is the most preferred one, because the other two methods present the possibility of genetic variation owing to the dedifferentiated phase, callus (Ota $\mathbb{\&}$ Yokoyama 2010).

Cytokinins are a group of phytohormones that stimulate water uptake, increase cell division, promote organ development and even lead to shoots regeneration and proliferation. Kinetin (6-furfurylaminopurin) is an example of a synthetic cytokinin that has evidence of being able to mitigate the adverse effects of salt stress during plant growth (Eser et al., 2016). This phytohormone was found in 1955 as a cell division hormone, leading Skoog and Miller in 1957 to arise the concept of hormonal control for organ formation by adjusting the concentration of auxins and cytokines in the medium (Dias et al., 2016).

In fact, well-established cultivation conditions have revealed to be determinant for both plant production and bioactive compounds concentration, acting as conditioners of the biological activity. On the other hand, conservation conditions have also been pointed out as having a direct effect on both bioactive constituents concentration and, consequently, on stevia biological activity (Pinela et al., 2011). 


\subsection{Objectives}

Considering that both cultivation and conservation conditions seem to exert a crucial role on S. rebaudiana biological activity, the present work aimed to:

i) Evaluate the effects of the dehydration process on S. rebaudiana antioxidant potential, by comparing the free radical scavenging activity, reducing power, and antioxidant compounds of fresh frozen and dried plants. It should be highlighted that the studied samples were obtained in an experimental field with defined cultivation conditions in order to standardize stevia production and, therefore, chemical composition.

ii) Assess the effect of different $\mathrm{N}$ rates on the chemical composition of stevia frozen fresh and dried leaves, and to define the best growing conditions to maximize the levels of these compounds.

iii) Analyze leaves obtained by in vitro culture in terms of antioxidants; more specifically, samples obtained in the presence of kinetin will be compared with samples cultured without this phytohormone, in terms of tocopherols, free sugars and phenolic compounds, and lastly antioxidant properties. 
MATERIALS AND

METHODS 


\section{MATERIALS AND METHODS}

\subsection{Plant samples}

Stevia rebaudiana Bert. (stevia) samples were cultivated in Bragança, Trás-os-Montes, North-eastern Portugal, under specific culture conditions. The field trial supporting this study was carried out in Vilariça region (41.191373; -7.103809), NE Portugal, which benefits from a Mediterranean climate (Figure 5). The mean annual temperature and accumulated precipitation in the period from 1971-2000 were, respectively, $14.3^{\circ} \mathrm{C}$ and 509 $\mathrm{mm}$.

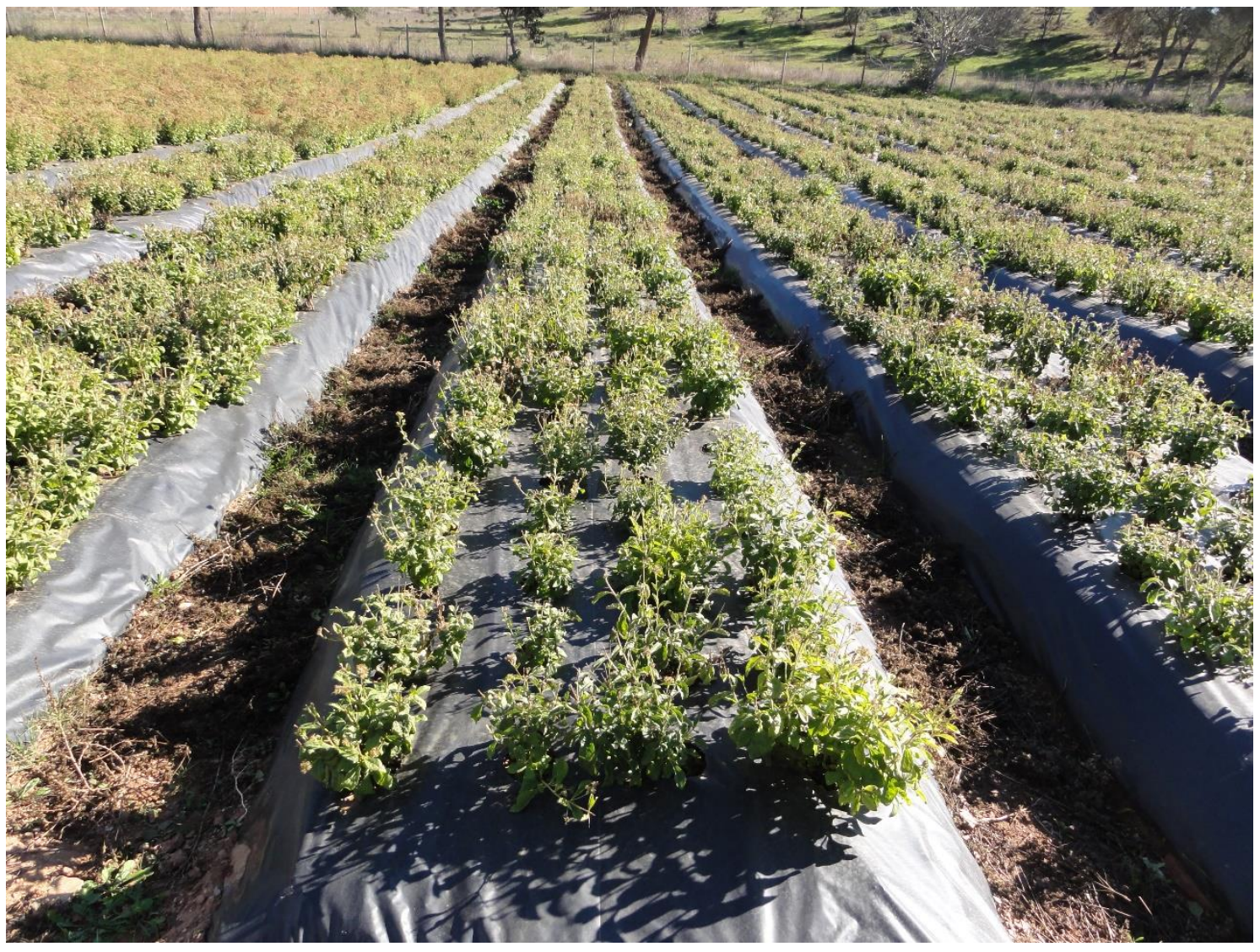

Figure 5. Field trial supporting stevia cultivation. 


\subsection{Cultivation procedure}

To evaluate the processing effects: The soil was a Regosol of colluvial origin, loamy textured (23.9\% clay, $21.8 \%$ silt, $54.4 \%$ sand), slightly acidic $\left[\mathrm{pH}_{(\mathrm{H} 2 \mathrm{O})} 6.3\right]$, and low in organic carbon (Walkley-Black) $5.6 \mathrm{~g} / \mathrm{kg}$. The soil was covered with anti-weed screen punched with holes spaced at $50 \times 40 \mathrm{~cm}$ after the installation of the drip irrigation system (Figure 5). Cuttings of 10-15 cm height, previously placed on rooting in a greenhouse (Figure 6), were planted in the holes opened in the screen. The cuttings were obtained from a farmer's field grown with cv. Morita. Crop plantation occurred in June $13^{\text {th }}$, 2014. Plants were watered twice a week throughout the growing season. The harvest took place in August $5^{\text {th }}, 2014$, and subsamples consisting of three whole plants were separated in fresh stems and leaves.

To evaluate the fertilization effects: The field trial was established in a Fluvisol, loam textured (16.1\% clay, $41.3 \%$ silt, $42.6 \%$ sand), $\mathrm{pH}_{(\mathrm{H} 2 \mathrm{O})} 6.1$, organic carbon $9.9 \mathrm{~g} / \mathrm{kg}$ and extractable (Egner-Rhiem) $\mathrm{P}\left(\mathrm{P}_{2} \mathrm{O}_{5}\right)$ and $\mathrm{K}\left(\mathrm{K}_{2} \mathrm{O}\right)$ at 39.5 and $240 \mathrm{mg} / \mathrm{kg}$, respectively. The field trial included four $\mathrm{N}$ concentrations $(0,25,50,100 \mathrm{~kg} \mathrm{~N} / \mathrm{ha})$ and was arranged as a completely randomized design, with three replications. Nitrogen was supplied as an organic amendment containing $6 \% \mathrm{~N}, 3 \% \mathrm{P}\left(\mathrm{P}_{2} \mathrm{O}_{5}\right)$ and $2 \% \mathrm{~K}\left(\mathrm{~K}_{2} \mathrm{O}\right)$. A drip irrigation system was installed after soil preparation and covered with an anti-weed screen. Plants were grown in holes made in a screen spaced at $50 \times 40 \mathrm{~cm}$. The cuttings, previously rooted in a greenhouse (Figure 6), were planted on June $11^{\text {th }}$ 2014, and the harvest took place in August $5^{\text {th }} 2014$.

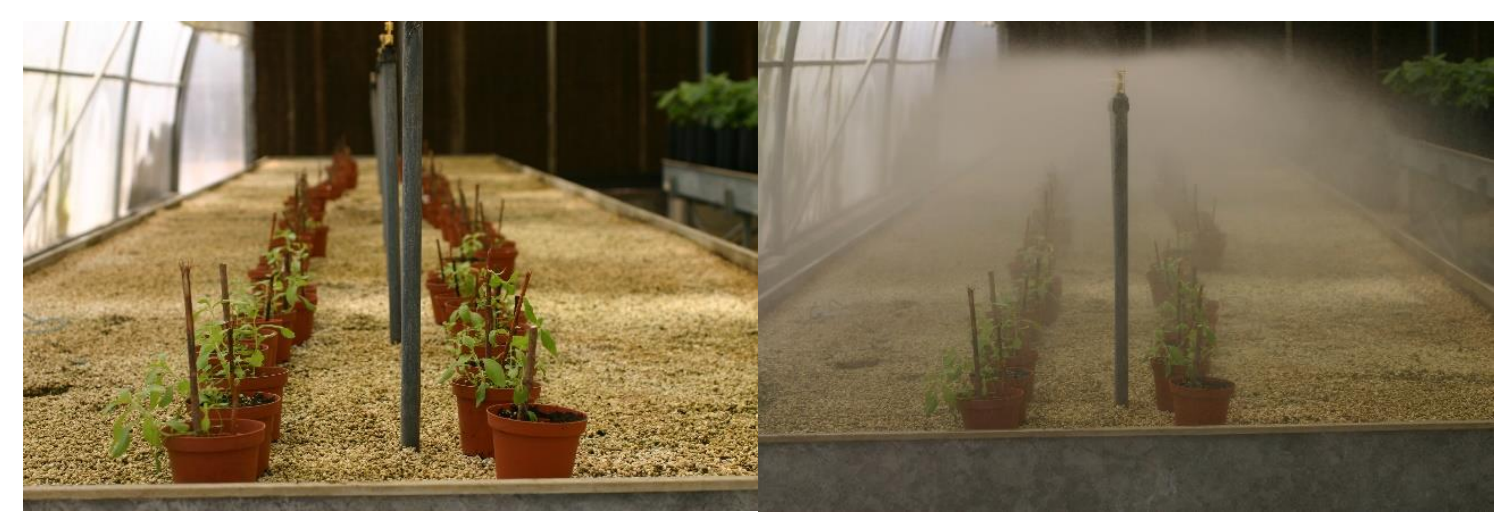

Figure 6. Greenhouse with the cuttings of stevia previously rooted. 


\subsection{In vitro micropropagation}

The plant material was obtained from a commercial clone grown in the field, previously mentioned in section 2.1. Three different plants were used to perform micropropagation inoculations, starting with 20 tubes in the first inoculation. The explants for in vitro culture were harvested in August and consisted of the whole plant. Afterwards, they were separated in stems and leaves, in order to collect stems with nodes for inoculation (axillar meristems), being leaves discarded. Then, stems with nodes were washed in tap water and the surface sterilized by agitation for 7 minutes in a solution of chlorine 5\%, plus 10 drops of tween 80 per $100 \mathrm{~mL}$ of sterilizing solution. After washing in sterilized water, explants were moved to a solution of ethanol $70 \%$ for 5 minutes, washed and inoculated in two different culture media (medium A - MS- Murashige and Skoog, 1962 without hormones and $20 \mathrm{~g} / \mathrm{L}$ of sucrose - and medium B - MS with $0.5 \mathrm{mg} / \mathrm{L}$ of kinetin and $20 \mathrm{~g} / \mathrm{L}$ of sucrose) (Figure 7). The culture media were adjusted to a $5.7 \mathrm{pH}$ before autoclaving and placed in round flask tubes $(13.5 \times 3 \mathrm{~cm}, 10 \mathrm{~mL})$. The culture conditions were $\operatorname{Tmin}[16-18]^{\circ} \mathrm{C}$, $T \max [24-26]^{\circ} \mathrm{C}$ with a photoperiod of 16/8 h (light/dark) supplied by light-bulbs Silvana day light (Phillips, Amsterdam, Netherlands). The multiplication rate was determined for each subculture of 2 months in the two-media tested.

Leaves for chemical analyses were collected from in vitro plants after 3 subcultures (2 months), and after achieving 1 to $1.5 \mathrm{~cm}$ of length.
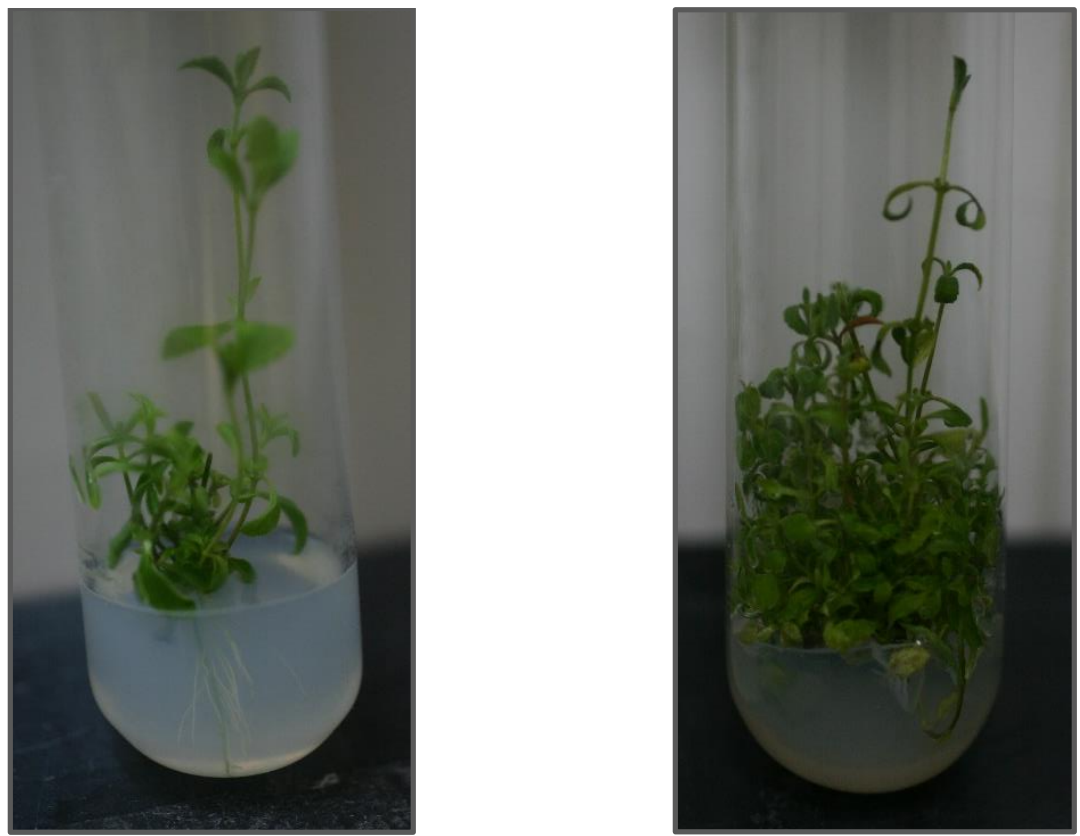

Figure 7. In vitro stevia micropropagation: Left photo Medium A; right photo Medium B. 


\subsection{Collection and treatment of the samples}

After the collection, the specimens (leaves) were separated into two similar halves and placed in paper bags. Half of the samples were dried at $30{ }^{\circ} \mathrm{C}$ (Memmert oven, Edelstahl Rostfrei, Germany) for six days, while the other half were immediately frozen $\left(-20{ }^{\circ} \mathrm{C}\right)$ for the same period (Figure 8), being lyophilized (FreeZone 4.5, Labconco, Kansas City, MO, USA) at the end of the six-day period to be stored until analyses and in order to further express the results in dry weight basis to be comparable with the oven-dried samples. These last samples were designated as fresh frozen samples. For the in vitro obtained stevia, after 2 months, subculture micropropagated samples (leaves) were immediately frozen $\left(-20{ }^{\circ} \mathrm{C}\right)$ and further lyophilized, as described for field cultivated samples. All the samples were reduced to a fine powder ( $20 \mathrm{mesh})$ and stored in a desiccator protected from light for subsequent assays.
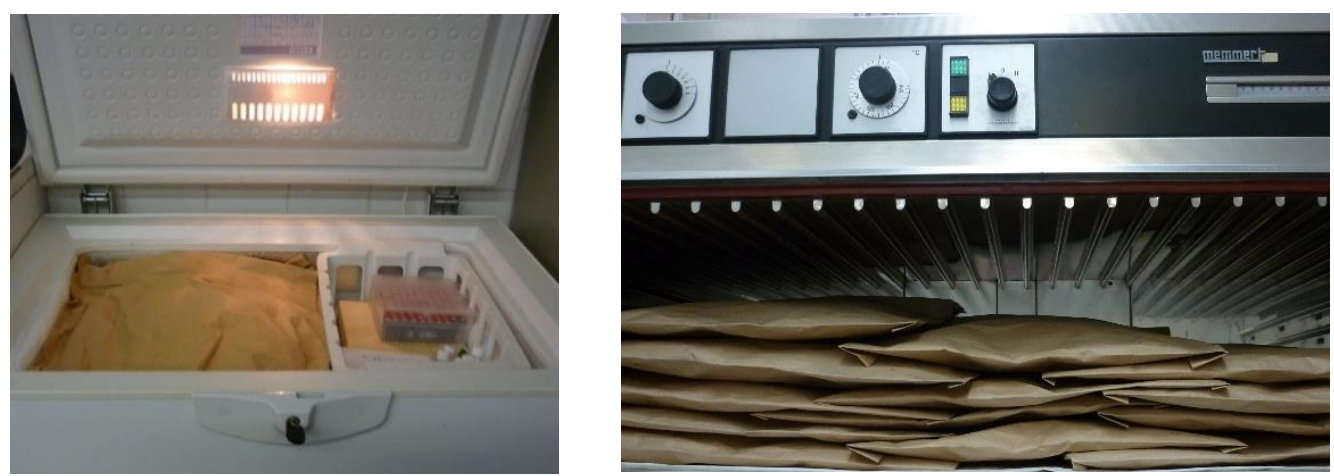

Figure 8. Processing of stevia samples: left photo, frozen at $-20^{\circ} \mathrm{C}$; right photo, dried-oven at $30^{\circ} \mathrm{C}$.

\subsection{Standards and reagents}

Acetonitrile HPLC-grade and formic acid were obtained from Lab-Scan (Lisbon, Portugal). Racemic tocol $(50 \mathrm{mg} / \mathrm{mL})$ and tocopherol $(\alpha-, \beta$-, $\lambda$-, and $\delta$-isoforms) standards were purchased from Matreya (Pleasant Gap, PA, USA). 2,2-Diphenyl-1-picrylhydrazyl (DPPH) was obtained from Alfa Aesar (Ward Hill, MA, USA). Phenolic compound standards were from Extrasynthèse (Genay, France). Trolox (6-hydroxy-2,5,7,8- tetramethylchroman-2carboxylic acid) and free sugar ((D(-)-fructose, $\mathrm{D}(+)$-sucrose, $\mathrm{D}(+)$-sucrose, $\mathrm{D}(+)$-trehalose and $\mathrm{D}(+)$-raffinose pentahydrate) standards were purchased from Sigma-Aldrich (St. Louis, MO, USA). Kinetin was from Merck (Darmstadt, Germany) and sucrose from J.T. Baker (Deventer, Deutschland). All other chemicals were of analytical grade. Water was treated in a Milli-Q water purification system (TGI Pure Water Systems, Greenville, SC, USA). 


\subsection{Free sugars}

Dried sample powder (1.0 g) was spiked with melezitose as internal standard (IS, 25 $\mathrm{mg} / \mathrm{mL})$, and extracted with $40 \mathrm{~mL}$ of $80 \%$ ethanol/water $(80: 20, \mathrm{v} / \mathrm{v})$ at $80{ }^{\circ} \mathrm{C}$ for $1: 30 \mathrm{~min}$, with shaking every $15 \mathrm{~min}$. The resulting suspension was centrifuged (Centurion $\mathrm{K}_{2} 4 \mathrm{OR}$ refrigerated centrifuge, West Sussex, UK) at $4000 \mathrm{rpm}$ for $5 \mathrm{~min}$. The supernatant was concentrated at $60{ }^{\circ} \mathrm{C}$ under reduced pressure and defatted three times with $10 \mathrm{~mL}$ of ethyl ether, in a separating funnel, successively. After concentration at $40{ }^{\circ} \mathrm{C}$ overnight. The solid residues were dissolved in water to a final volume of $5 \mathrm{~mL}$ and filtered through $0.2 \mu \mathrm{m}$ Whatman nylon filters (Pinela et al., 2011) (Figure 9).

The free sugars profile was determined using the HPLC equipment described above, connected to a RI detector (Knauer Smartline 2300). The chromatographic separation was carried out using a Eurospher 100-5 NH2 column $(4.6 \times 250 \mathrm{~mm}, 5 \mu \mathrm{m}$, Knauer), operating at $35^{\circ} \mathrm{C}$ (7971 R Grace oven). Mobile phase consisted of an acetonitrile/deionized water mixture, 70:30 (v/v), at a flow rate of $1 \mathrm{~mL} / \mathrm{min}$. Sugars were identified by chromatographic comparison using a Clarity 2.4 Software (DataApex, Prague, Czech Republic) and quantitation was carried out using IS methodology. Results were expressed in g per $100 \mathrm{~g}$ of dry weight (dw).

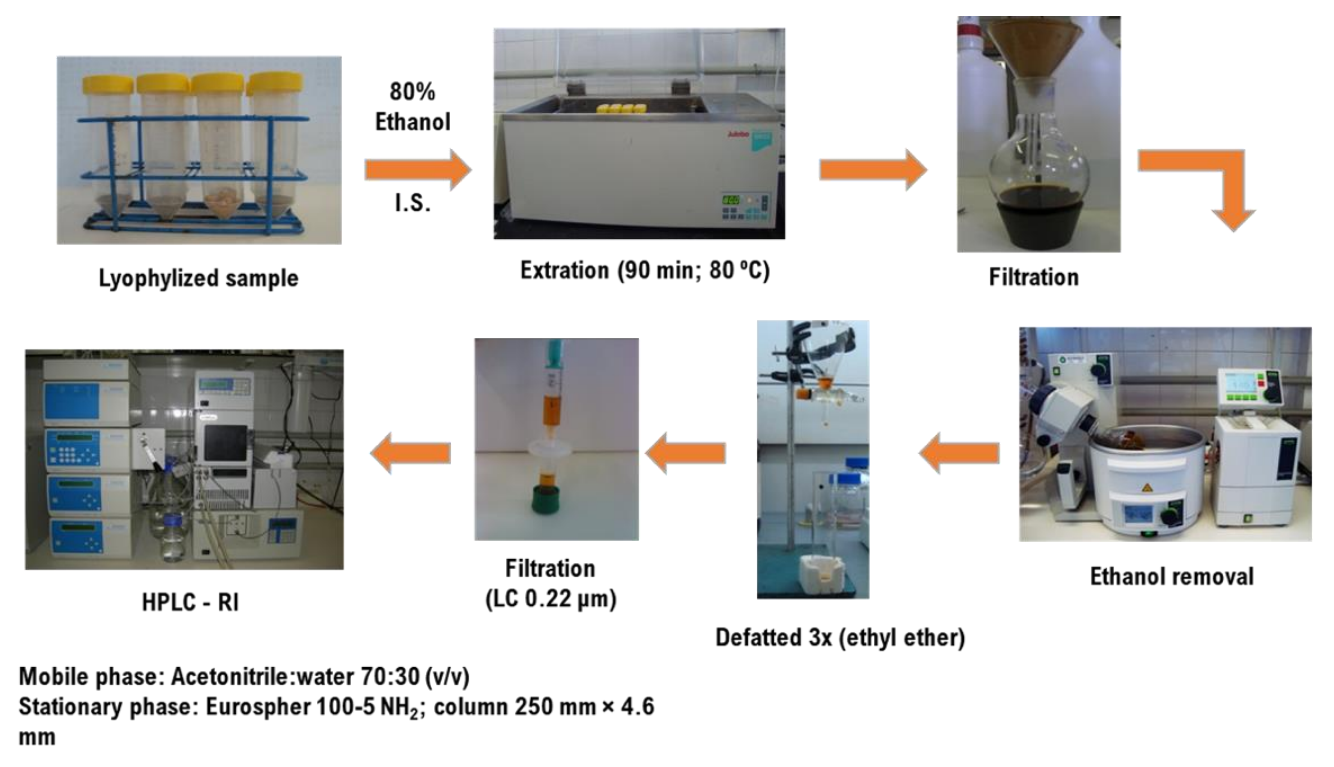

Figure 9. Depiction of the free sugar analysis. 


\subsection{Tocopherols}

Tocopherols were determined after performing an extraction procedure. BHT solution in hexane $(10 \mathrm{mg} / \mathrm{mL} ; 100 \mu \mathrm{L})$ and internal standard (IS) solution in hexane (tocol; $50 \mu \mathrm{g} / \mathrm{mL}$; $400 \mu \mathrm{L}$ ) were added to the sample prior to the extraction procedure. The samples (approximately $500 \mathrm{mg}$ ) were homogenized with methanol $(4 \mathrm{~mL})$ by vortex mixing (1 min). After that, hexane $(4 \mathrm{~mL})$ was added and again vortex mixed for $1 \mathrm{~min}$. Subsequently, saturated $\mathrm{NaCl}$ aqueous solution $(2 \mathrm{~mL})$ was added, the mixture was homogenized (1 min), centrifuged ( $5 \mathrm{~min}, 4000 \mathrm{~g}$ ) and the clear upper layer was carefully transferred to a vial. The methanol phase was re-extracted twice with hexane. The combined extracts were taken to dryness under a nitrogen stream, redissolved in $2 \mathrm{~mL}$ of n-hexane, centrifuged ( $5 \mathrm{~min}, 4000$ $g, 10^{\circ} \mathrm{C}$ ). Anhydrous sodium sulfate was added to dehydrate the sample, then it was filtered through an $0.2 \mu \mathrm{m}$ nylon filter from Whatman, and transferred into a dark injection vial for the chromatographic analysis (Figure 10) (Pinela et al., 2011).

The identification and separation were performed using an HPLC equipment consisting of an integrated system with a pump (Knauer, Smartline system 1000, Brelin, Germany), degasser (Smartline manager 5000), auto-sampler (AS-2057 Jasco, Easton, MD) and a fluorescence detector (FP-2020; Jasco). Data were analysed using Clarity 2.4 Software (DataApex). The fluorescence detector was programmed for excitation ( $\lambda$ ex) at $290 \mathrm{~nm}$ and emission $(\lambda \mathrm{em})$ at $330 \mathrm{~nm}$. The chromatographic separation was achieved with a Polyamide II (250 mm x $4.6 \mathrm{~mm}$ i.d.) normal-phase column from YMC Waters operating at $35^{\circ} \mathrm{C}$. The mobile phase used was a mixture of n-hexane and ethyl acetate $(70: 30, \mathrm{v} / \mathrm{v})$ at a flow rate of $1 \mathrm{~mL} / \mathrm{min}$, and the injection volume was $10 \mu \mathrm{L}$ (Figure 10). The compounds were identified by chromatographic comparisons with authentic standards. Quantification was based on calibration curves obtained from commercial standards of each compound using the internal standard (IS, tocol) methodology. The results were expressed in $\mathrm{mg} / 100 \mathrm{~g}$ of dry weight $(\mathrm{dw})$. 


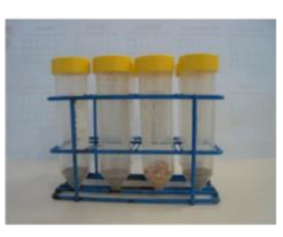

Lyophilized sample

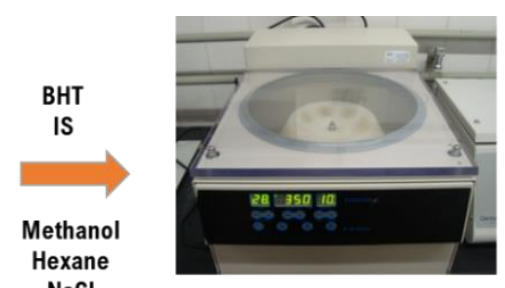

Centrifugation $\left(10^{\circ} \mathrm{C} ; 4000 \mathrm{~g} ; 5 \mathrm{~min}.\right)$

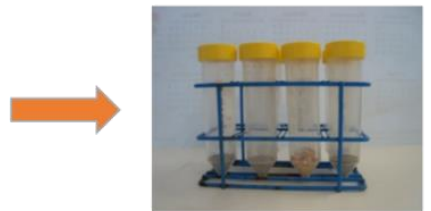

Re-extraction with hexane

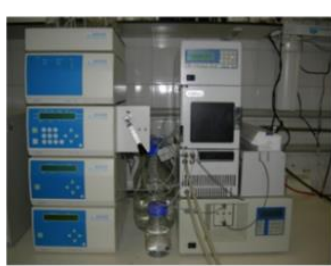

HPLC - fluorescence

Mobile phase- $n$-hexane:ethyl acetate $(70: 30, v / v)$

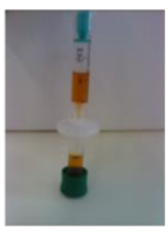

Filtration LC $0.22 \mu \mathrm{m}$

Stationary phase-Polyamide II column in normal phase $(250 \mathrm{~mm} \times 4.6 \mathrm{~mm})$

Figure 10. Depiction of tocopherol analysis.

\subsection{Extracts preparation}

Hydroalcoholic extracts were prepared by stirring the plant material $(1 \mathrm{~g})$ with $30 \mathrm{~mL}$ of methanol:water $(80: 20, \mathrm{v} / \mathrm{v})$ at $25^{\circ} \mathrm{C}$, applying a stirring agitation at $150 \mathrm{rpm}$ for $1 \mathrm{~h}$, and then filtered through Whatman No. 4 paper. The final residue was re-extracted with an additional $30 \mathrm{~mL}$ portion of the hydroalcoholic mixture. After this, both extracts were combined and evaporated at $35{ }^{\circ} \mathrm{C}$ under reduced pressure (rotary evaporator Büchi R-210, Flawil, Switzerland) to remove the methanol, the aqueous phase was frozen and then lyophilized. Finally, the lyophilized extracts were re-dissolved in methanol/water (80:20, $\mathrm{v} / \mathrm{v}$ ) at a final concentration of $5 \mathrm{mg} / \mathrm{mL}$ (Figure 11), for phenolic compounds determination and antioxidant activity evaluation. Stock solutions were further diluted at different concentrations to perform the distinct in vitro assays.
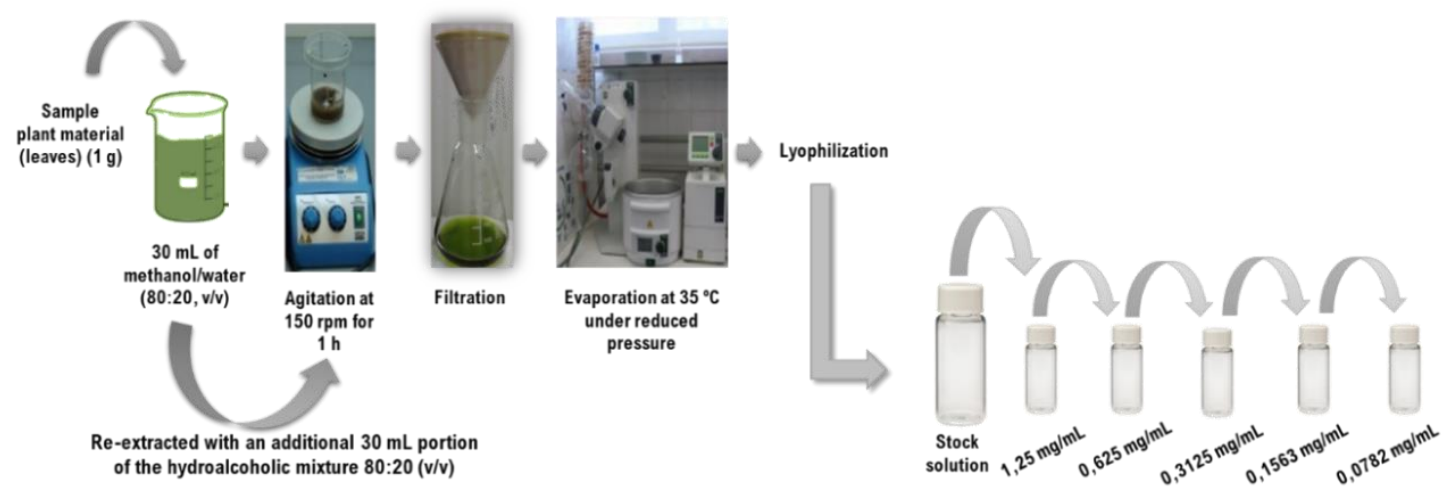

Figure 11. Overall procedure for extracts preparation. 


\subsection{Evaluation of in vitro antioxidant properties}

To assess the in vitro antioxidant potential of stevia samples, two different assays were selected: scavenging effects on DPPH (2,2-diphenyl-1-picrylhydrazyl) radicals and reducing power (measured by ferricyanide Prussian blue assay).

\subsubsection{Scavenging effects on DPPH radicals}

This methodology was performed using an ELX800 Microplate Reader (Bio-Tek, Bedfordshire, UK). DPPH radical-scavenging activity was assessed by using different concentrations of extracts $(30 \mu \mathrm{L})$, mixed in a 96-well plate (Figure 12) with a methanol solution $(270 \mu \mathrm{L})$ containing DPPH radicals $\left(6 \times 10^{-5} \mathrm{mM}\right)$, and then left to stand for $60 \mathrm{~min}$ in the dark. Reduction of DPPH radical is accompanied by a change in colour from purple to pale yellow (Figures 12 and 13) and determined by measuring the absorption at $515 \mathrm{~nm}$. The radical scavenging activity (RSA) was calculated as a percentage of DPPH discolouration using the Equation 1.

$$
\begin{gathered}
\mathrm{RSA}=[(\mathrm{ADPPH}-\mathrm{AS}) / \mathrm{ADPPH}] \times 100 \\
\mathrm{RSA}=\text { radical scavenging activity } \\
\mathrm{AS}=\text { absorbance of the solution containing the sample at } 515 \mathrm{~nm} \\
\mathrm{ADPPH}=\text { absorbance of the DPPH solution }
\end{gathered}
$$

Equation 1. Formula used to calculate the percentage of DPPH discoloration.

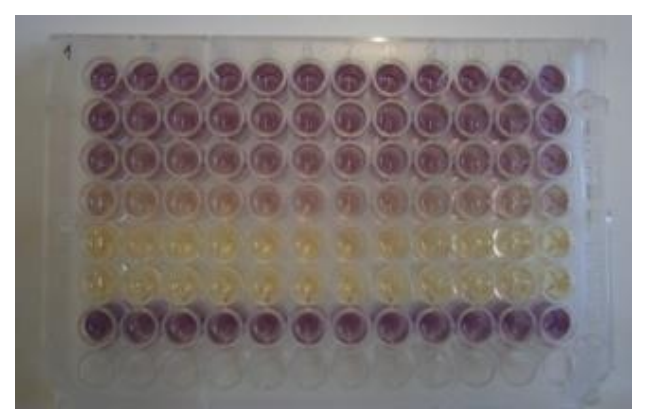

Figure 12. Depiction of a DPPH scavenging activity assay with the strongest (more antioxidant) concentrations showing a yellow tone. 


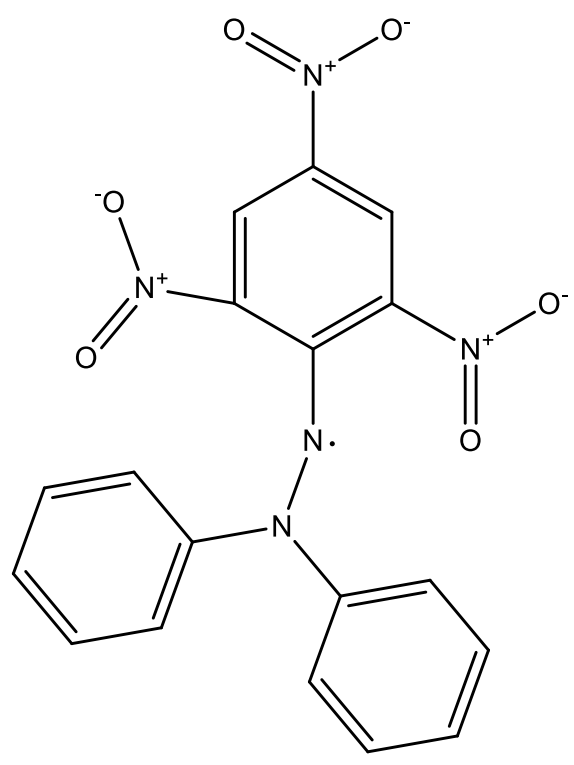

Purple

2,2-diphenyl-1-picrylhydrazyl

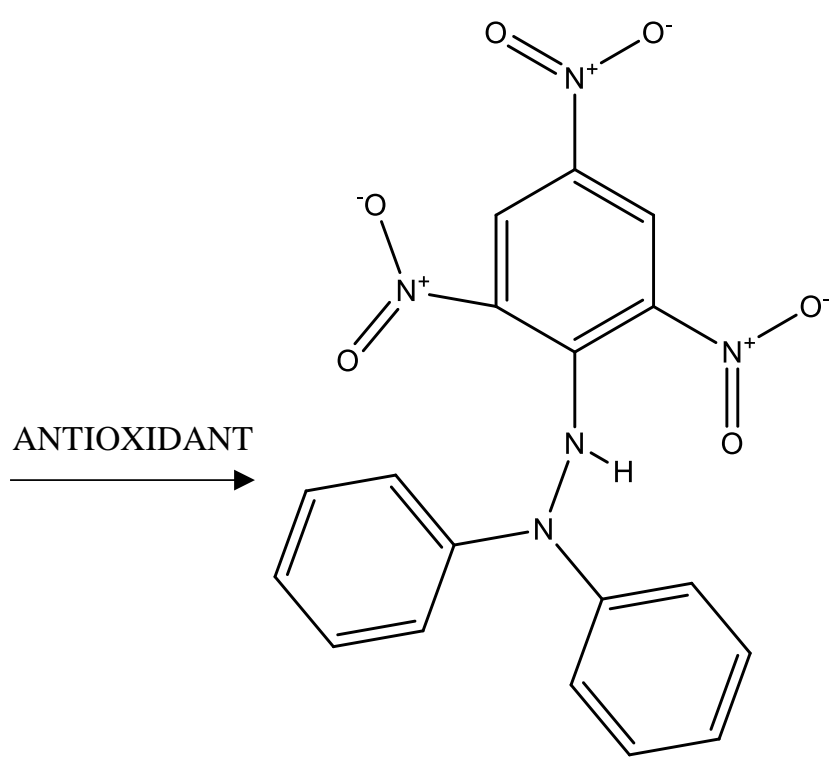

Pale yellow 2,2-diphenyl-1-picrylhydrazine

Figure 13. Reduction of the DPPH radical.

The results were expressed in $\mathrm{EC}_{50}$ values (extract concentration providing $50 \%$ of antioxidant activity) and calculated from the graph of DPPH scavenging activity against extract concentrations.

\subsubsection{Reducing power}

The assay is based on the capacity of a sample to convert $\mathrm{Fe}^{3+}$ to $\mathrm{Fe}^{2+}$, this reduction is accompanied by a change in colour from yellow to Prussian blue (Figure 14), measuring the absorbance at $690 \mathrm{~nm}$ in the microplate reader mentioned above. Several concentrations of extracts $(500 \mu \mathrm{L})$ were mixed in an Eppendorf $(2 \mathrm{~mL})$ with sodium phosphate buffer $(\mathrm{pH}$ 6.6, $200 \mathrm{mM}, 500 \mu \mathrm{L})$ and potassium ferricyanide $(1 \% w / v, 500 \mu \mathrm{L})$, and then incubated at $50{ }^{\circ} \mathrm{C}$ for $20 \mathrm{~min}$. Trichloroacetic acid $(10 \%, 500 \mu \mathrm{L})$ was subsequently added and the upper layer $(800 \mu \mathrm{L})$ was mixed with deionised water $(800 \mu \mathrm{L})$ and ferric chloride $(0.1 \%, 160 \mu \mathrm{L})$ in a 48-wells plate (Figure 14), and the absorbance spectrophotometrically measured at 690 $\mathrm{nm}$. 


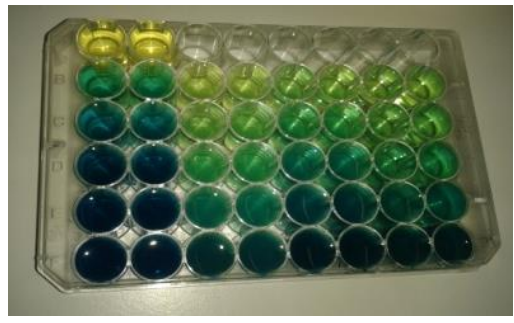

Figure 14. Multiwell plate showing samples prepared for measurement of the reducing power assay. The stronger the antioxidant concentrations the darker the Prussian blue tone.

The reducing power method is characterized by the reduction of complex $\mathrm{Fe}$ (III)/ferricyanide $\left[\mathrm{FeCl}_{3} / \mathrm{K}_{3}(\mathrm{CN})_{6}\right]$ to $\mathrm{Fe}$ (II) $\left(\mathrm{Fe}^{3+}\right.$ to $\left.\mathrm{Fe}^{2+}\right)$ depending on the available reducing species (Equation 2).

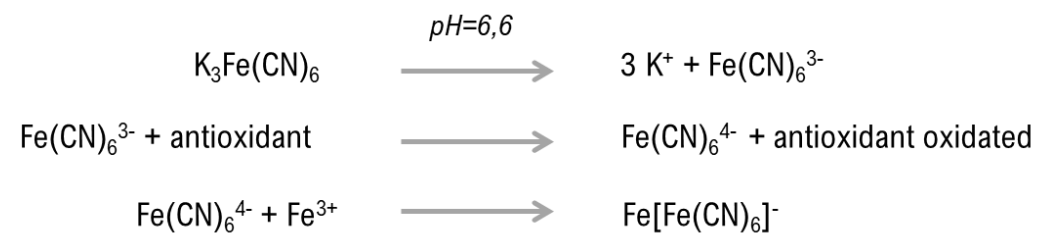

Equation 2. Reaction pairs for the reducing power assay.

Results were expressed in $\mathrm{EC}_{50}$ values, corresponding to the sample concentration that provide 0.5 of absorbance in the reducing power assay (50\% of antioxidant activity). Trolox was used as standard.

\subsection{Analysis of phenolic compounds}

The extracts described in section 2.8 were analysed using a Hewlett-Packard 1100 chromatograph (Agilent Technologies) with a quaternary pump and a diode array detector (DAD) coupled to an HP Chem Station (rev. A.05.04) data-processing station. A Waters Spherisorb S3 ODS-2 $\mathrm{C}_{18}(4.6 \mathrm{~mm} \times 150 \mathrm{~mm}, 3 \mu \mathrm{m}$; Lisbon, Portugal $)$ column thermostatted at $35^{\circ} \mathrm{C}$ was used for separation. The mobile phase consisted of two solvents: (A) $0.1 \%$ formic acid in water, and (B) acetonitrile, establishing the following elution gradient: $15 \%$ B for $5 \mathrm{~min}, 15 \%$ B to $20 \%$ B over 5 min, 20-25\% B over 10 min, 25-35\% B over 10 min, $35-50 \% \mathrm{~B}$ for $10 \mathrm{~min}$, and re-equilibration of the column, using a flow rate of $0.5 \mathrm{~mL} / \mathrm{min}$. Double online detection was carried out in the DAD using $280 \mathrm{~nm}$ and $370 \mathrm{~nm}$ as preferred 
wavelengths and in a mass spectrometer (MS) connected to HPLC system via the DAD cell outlet (Figure 15).

MS detection was performed in an API 3200 Qtrap (Applied Biosystems, Darmstadt, Germany) equipped with an ESI source and a triple quadrupole-ion trap mass analyser that was controlled by the Analyst 5.1 software. Zero grade air served as the nebulizer gas (30 psi) and turbo gas for solvent drying $\left(400^{\circ} \mathrm{C}, 40 \mathrm{psi}\right)$. Nitrogen served as the curtain (20 psi) and collision gas (medium). The quadrupols were set at unit resolution. The ion spray voltage was set at $-4500 \mathrm{~V}$ in the negative mode and spectra were recorded between $\mathrm{m} / \mathrm{z} 100$ and 1500. The MS detector was programmed for recording in two consecutive modes: enhanced MS (EMS) and enhanced product ion (EPI) analysis. EMS was employed to show full scan spectra, so as to obtain an overview of all of the ions in sample. Settings used were: declustering potential (DP) $-450 \mathrm{~V}$, entrance potential (EP) $-6 \mathrm{~V}$, collision energy (CE)-10 $\mathrm{V}$. EPI mode was performed in order to obtain the fragmentation pattern of the parent ion(s) in the previous scan using the following parameters: DP $-50 \mathrm{~V}, \mathrm{EP}-6 \mathrm{~V}, \mathrm{CE}-25 \mathrm{~V}$, and collision energy spread (CES) $0 \mathrm{~V}$.

The phenolic compounds were identified by comparing their retention time, UV-vis and mass spectra with those obtained from standards, when available. Otherwise, peaks were tentatively identified from their absorption and mass spectra and comparison with data reported in the literature. For quantitative analysis, a calibration curve for each available phenolic standard was constructed based on the area of the peak at the detection wavelength used in the HPLC-DAD analysis. For the identified phenolic compounds for which a commercial standard was not available, the quantification was performed through the calibration curve of a compound from the same phenolic group. The results were expressed in $\mathrm{mg} / \mathrm{g}$ of extract.

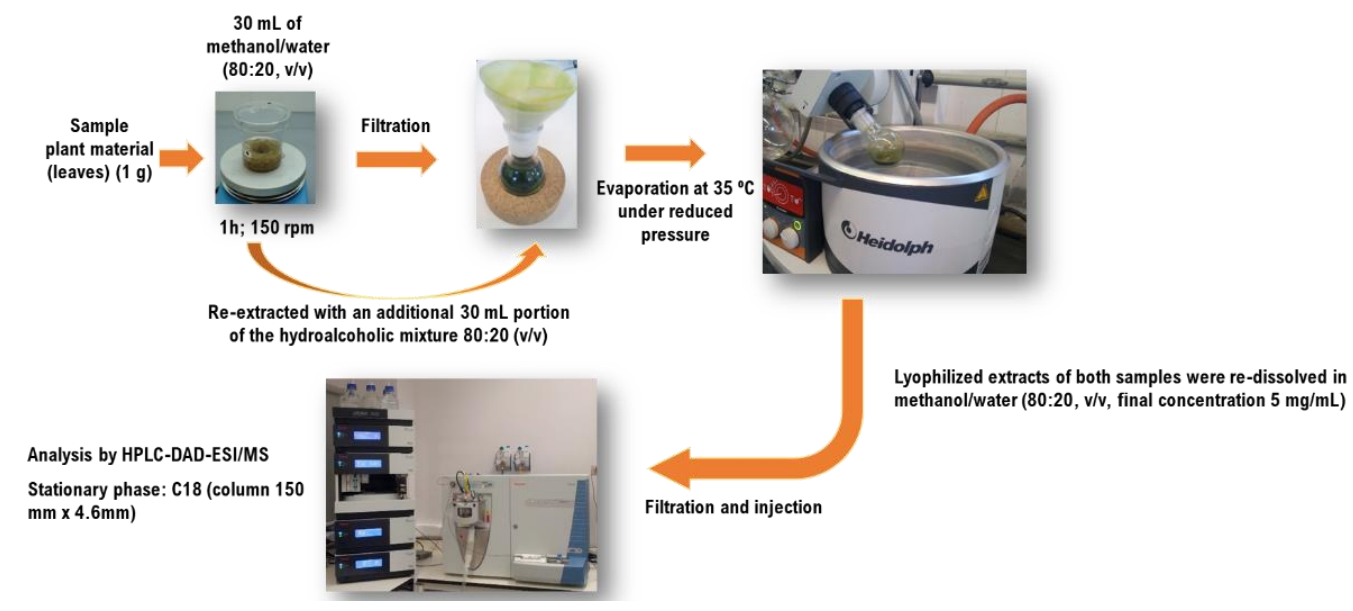

Figure 15. Depiction of the phenolic compounds, filtration and injection. 


\subsection{Statistical analysis}

For all the assays three different samples for each preparation were used and all the assays were carried out in triplicate, and the results were expressed as mean values and standard deviation (SD).

For comparison of the samples submitted to different conservation conditions, and also the ones obtained in vitro with kinetin, the statistical analysis was carried out using a Student's t-test to determine the significant difference among two different samples, with $\alpha=0.05$. This treatment was carried out using SPSS v. 23.0 program (IBM Corp., Armonk, New York, USA).

For the assessment study of the effect of nitrogen fertilization in samples with different conservation conditions, the experimental data were checked for normality (Shapiro-Wilk test) and homogeneity of variances (Levene's test) assumptions. When it was not possible to apply an analysis of variance (ANOVA) and for data that did not follow a normal distribution, non-parametric tests were performed to evaluate significant differences at a level of 5\%, using the EXCEL software, Microsoft Office Professional Plus 2010, version 14.0.7159.5000, with the add-in Analysis ToolPak (Microsoft Corp., USA). For each factor, $\mathrm{N}$ or Process, the results were grouped regardless of process (frozen fresh or dried) and regardless each $\mathrm{N}$ content, respectively. For $\mathrm{N}$, the results are presented as the mean value regardless of the process (frozen fresh or dried). For the Process, the results are presented as the mean value regardless of $\mathrm{N}$ content. The standard deviations presented in the tables should not be regarded as a measure of accuracy of the methodologies, since they include the results for one of the factors (Process or N). Furthermore, a Pearson's correlation analysis between the antioxidant activity and all the analysed compounds was carried out, with a 95\% confidence level, using an IBM SPSS Statistics software, version 23. 
RESULTS AND
DISCUSSION 


\section{RESULTS AND DISCUSSION}

\subsection{Stevia rebaudiana Bertoni cultivated in Portugal: A prospective study of its antioxidant potential in different conservation conditions}

\subsubsection{Tocopherols and sugars composition}

The tocopherol contents determined in the oven-dried and frozen fresh samples of $S$. rebaudiana are given in Table $\mathbf{1}$, with the presence of three isoforms $(\alpha-, \gamma$ - and $\delta$ tocopherol), being $\alpha$-tocopherol the majority compound in both samples. The highest value of total tocopherols was obtained in the frozen fresh samples, which is in concordance with Pinela et al. (2011), who reported a decrease in tocopherols content in Cytisus and Genista plant species after shade drying. The higher concentration of $\alpha$-tocopherol in frozen fresh samples in comparison with the oven dried ones is also in agreement with the results obtained by those authors.

Regarding free sugars composition (Table 1), eight different sugars were detected in both oven-dried and frozen fresh samples: rhamnose, xylose, arabinose+fructose, glucose, sucrose, trehalose, and raffinose. In general, the highest values of total sugars were registered in frozen fresh samples, mostly due to their higher content of xylose, the major sugar in this sample. They also showed the highest concentration of glucose. No significant differences were obtained for rhamnose and trehalose concentrations. Otherwise and despite the lower values of total sugars, oven-dried samples gave higher concentration of arabinose+fructose, sucrose and raffinose than frozen fresh samples. Pinela et al. (2011) also reported a decrease in free sugars content of plant species from Cytisus and Genista genera after shade drying. Not only free sugars and tocopherols should be affected by the drying process, but also other important compounds in S. rebaudiana such as steviol glycosides, as described by Periche et al. (2015).

Sucrose was the major free sugar in the oven-dried samples $(4.26 \mathrm{~g} / 100 \mathrm{~g})$, as also reported by Pereira et al. (2015), who studied dried and commercial samples of S. rebaudiana (3.93 $\mathrm{g} / 100 \mathrm{~g})$. However, the profile obtained by those authors was dissimilar between both samples, with the commercial one showing only sucrose, fructose, glucose and trehalose. Karimi et al. (2015) also studied soluble sugars in S. rebaudiana, describing an increasing content (mainly glucose) with soil moisture depletion. They also identified fructose and sucrose, but in low levels. Differences in the chemical composition among samples from different origin might be related with photoperiod (Ceumen and Geuns, 2013), planting 
times, plant stands and harvest regime (Serfaty et al., 2013; Karimi et al., 2015). It should be highlighted that the majority of studies in S. rebaudiana that are available in the literature address to the evaluation of steviol (a diterpenoid) glycosides (Brandle and Telmer 2007; Gardana et al. 2010; Geuns et al. 2003; Periche 2015), the compound responsible for the sweet taste of this plant, and not the herein studied free sugars.

Table 1. Composition of Stevia rebaudiana leaves in tocopherols and free sugars (mean \pm SD).

\begin{tabular}{|c|c|c|c|}
\hline Compounds & Frozen fresh Samples & Oven-dried Samples & $\begin{array}{c}\text { t-Student test } \\
\text { p-value }\end{array}$ \\
\hline a-Tocopherol & $12.25 \pm 0.08$ & $5.83 \pm 0.01$ & $<0.001$ \\
\hline$\gamma$-Tocopherol & $0.20 \pm 0.01$ & $0.22 \pm 0.01$ & 0.013 \\
\hline$\delta$-Tocopherol & $0.25 \pm 0.01$ & $0.11 \pm 0.01$ & 0.001 \\
\hline Total $(\mathrm{mg} / 100 \mathrm{~g})$ & $12.70 \pm 0.10$ & $6.16 \pm 0.02$ & $<0.001$ \\
\hline Rhamnose & $0.55 \pm 0.02$ & $0.50 \pm 0.01$ & 0.001 \\
\hline Xylose & $9.76 \pm 0.15$ & $3.81 \pm 0.18$ & $<0.001$ \\
\hline Arabinose+Fructose & $2.04 \pm 0.13$ & $3.30 \pm 0.15$ & $<0.001$ \\
\hline Glucose & $0.26 \pm 0.01$ & $0.040 \pm 0.001$ & $<0.001$ \\
\hline Sucrose & $1.79 \pm 0.16$ & $4.26 \pm 0.17$ & $<0.001$ \\
\hline Trehalose & $0.45 \pm 0.05$ & $0.38 \pm 0.03$ & 0.005 \\
\hline Raffinose & $0.19 \pm 0.04$ & $0.88 \pm 0.04$ & $<0.001$ \\
\hline Total $(\mathrm{g} / 100 \mathrm{~g})$ & $15.04 \pm 0.18$ & $13.17 \pm 0.42$ & $<0.001$ \\
\hline
\end{tabular}




\subsubsection{Phenolic composition}

The phenolic compounds profile of the hydroalcoholic extract of $S$. rebaudiana leaves is shown in Figure 16. Data (retention time, $\lambda_{\max }$ in the visible region, pseudomolecular ion and main fragment ions observed in $\mathrm{MS}^{2}$ ) obtained by HPLC-DAD-ESI/MS analysis regarding phenolic compounds identification and individual quantification are presented in Table 2. Compounds 3, 6, 7 and 10 were positively identified as 5-O-caffeoylquinic acid, quercetin-3-O-rutinoside, quercetin-3-O-glucoside and kaempferol-3-O-glucoside respectively, by comparison with authentic standards and analysis of their MS fragmentation pattern, retention time and UV-vis characteristics. The presence of these compounds has already been reported in $S$. rebaudiana by different authors (Cacciola et al., 2011; Muanda et al., 2011; Karaköse et al., 2011, 2015; Shivanna et al., 2013; Barba et al., 2015; Gawel-Bęben et al., 2015).

Compounds 1 and $2\left([\mathrm{M}-\mathrm{H}]^{-}\right.$at $\left.m / z, 353\right)$ were identified as 3-O-caffeoylquinic acid and 4$O$-caffeoylquinic acid based on the fragmentation pattern and characteristics reported by Clifford et al. (2003, 2005). Peaks 8, 11 and $15\left([\mathrm{M}-\mathrm{H}]^{-}\right.$at $\left.\mathrm{m} / \mathrm{z}, 515\right)$ could be assigned as 3,4-O-, 3,5-O- and 4,5-O-dicaffeoylquinic acids, respectively, based on their elution order, fragmentation pattern and relative fragment ion abundances (Clifford et al., 2003, 2005). All those compounds have also been previously described in S. rebaudiana (Muanda et al., 2011; Karaköse et al., 2011, 2015; Shivanna et al., 2013), supporting their identification in this sample.

Peaks $4\left([\mathrm{M}-\mathrm{H}]^{-}\right.$at $\left.m / z 381\right)$ and $5\left([\mathrm{M}-\mathrm{H}]^{-}\right.$at $\left.m / z 391\right)$ presented a fragmentation pattern and UV-vis spectra similar to caffeic acid. Compounds showing a pseudomolecular ion at $\mathrm{m} / \mathrm{z}$ 381 were detected in other Asteraceae like Erigeron breviscapus and identified as caffeoyl2,7-anhydro-3-deoxy-2-octulopyranosonic acids (Zhang et al., 2007; Liao et al., 2011), identity that was tentatively assumed for the compound 4 detected herein. No structure could, however, be matched for peak 5 that remained unidentified as a caffeic acid derivative.

The rest of phenolic compounds were assigned to flavonol derivatives based on their characteristic UV spectra showing maximum wavelength of absorption $\left(\lambda_{\max }\right)$ around 345 $360 \mathrm{~nm}$ and the release of $\mathrm{MS}^{2}$ fragment ions at $\mathrm{m} / \mathrm{z} 301$ (quercetin) or 285 (kaempferol). Peaks 9, 13 and 14 ([M-H] $]^{-}$at $m / z 579,433$ and 447, respectively) were assigned to quercetin glycosides, and peaks 12 ([M-H] $]^{-}$at $\left.m / z 447\right), 16$ and 17 ([M-H] $]^{-}$at $\left.m / z 417\right)$, and 18 ([M$\mathrm{H}]^{-}$at $m / z$ 431) to kaempferol derivatives. They presented $\mathrm{MS}^{2}$ fragments corresponding to distinct losses of hexosyl (-162 u), deoxyhexosyl (-146 u) or pentosyl (-132 u) residues, 
although mass spectral characteristics did not allow characterising the position and nature of the sugar moieties. Similar compounds have already been reported in leaves of S. rebaudiana (Cacciola et al., 2011; Muanda et al., 2011; Karaköse et al., 2015; Shivanna et al., 2013). Among them, peaks 13 and 14 might be tentatively associated to quercetin-3- $O$-xyloside and quercetin-3-O-rhamnoside, previously identified in leaves of $S$. rebaudiana by Shivanna et al. (2013) and Cacciola et al. (2011), respectively.

The most abundant phenolic compounds in the studied samples were 5-O-caffeoylquinic acid (chlorogenic acid) and 3,5-O-dicaffeoylquinic acid. Oven-dried samples presented the highest total phenolic compounds concentration, because of the presence of much higher contents of phenolic acid derivatives, whereas the concentration of total flavonoids in both samples is similar. The lower levels of phenolic acid derivatives in frozen samples might be due to they are preferent substrates for polyphenol oxidases, which would remain active during freezing, while they are inhibited by the drying process. These enzymes could especially act during the defrosting stage favoured by tissue disruption that would allow enzymes and substrates to get in contact. As for the qualitative composition, oven-dried samples did not reveal the presence of quercetin-3-O-rutinoside (rutin) and quercetin- $O$ pentosyl-deoxyhexoside, while the frozen fresh sample did not present peak 12 (kaempferol$O$-hexoside). 

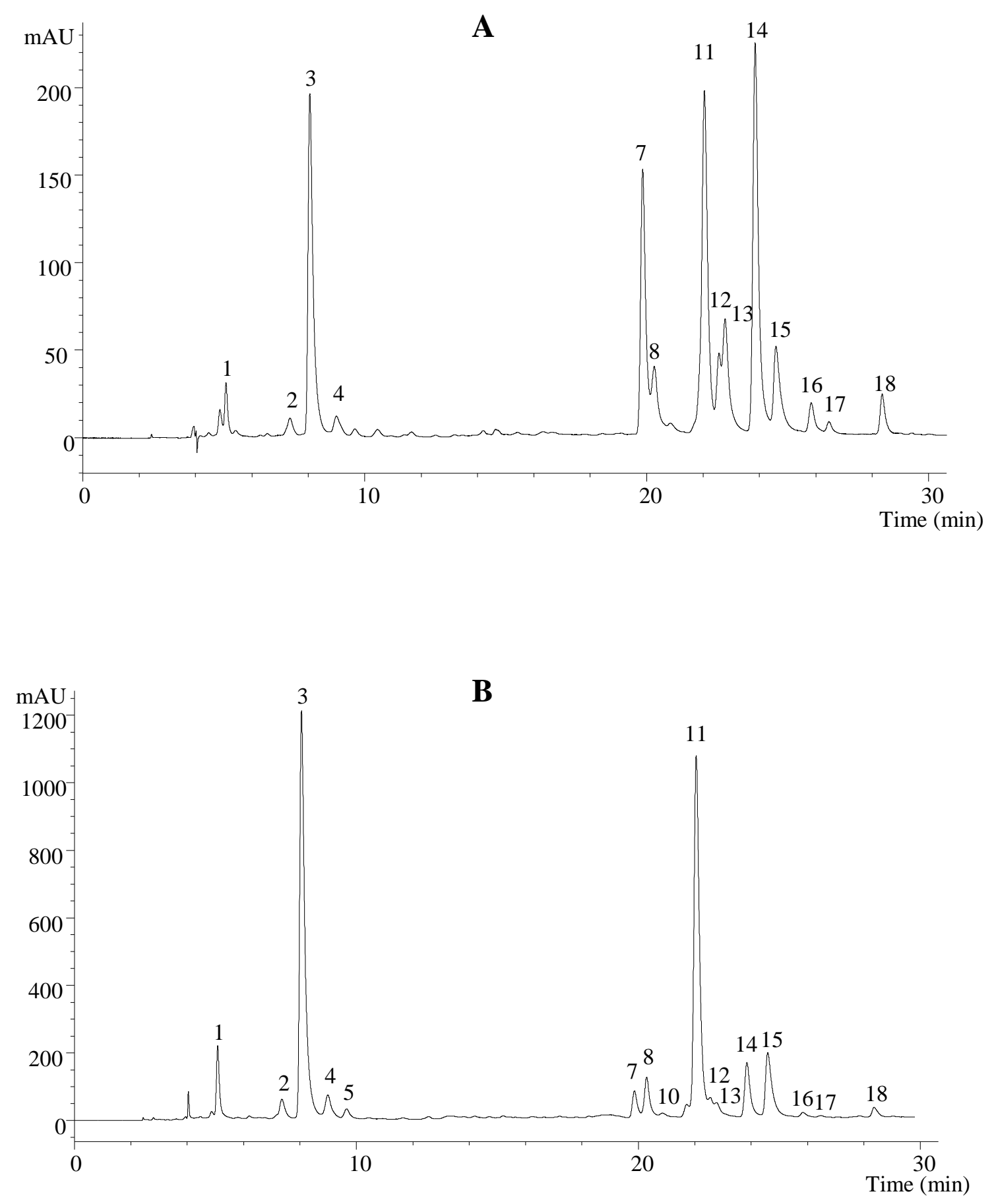

Figure 16. HPLC chromatograms showing the phenolic compounds profile of oven-dried Stevia rebaudiana leaves recorded at 370 (A) and 280 (B) $\mathrm{nm}$. 
Table 2. Phenolic compounds identification and quantification in Stevia rebaudiana leaves.

\begin{tabular}{|c|c|c|c|c|c|c|c|c|}
\hline \multirow[t]{2}{*}{ Compounds } & \multirow{2}{*}{$\begin{array}{l}\text { Rt } \\
\text { (min) }\end{array}$} & \multirow{2}{*}{$\begin{array}{l}\lambda_{\max } \\
(n m)\end{array}$} & \multirow{2}{*}{$\begin{array}{l}\text { Pseudomolecular } \\
\text { ion } \\
\quad[\mathrm{M}-\mathrm{H}]^{-}(\mathrm{m} / \mathrm{z})\end{array}$} & \multirow{2}{*}{$\begin{array}{l}M S^{2} \\
(m / z)\end{array}$} & \multirow{2}{*}{ Tentative identification } & \multicolumn{2}{|c|}{ Quantification (mg/g extract) } & \multirow{2}{*}{$\begin{array}{l}\text { t-Student } \\
\text { test p-value }\end{array}$} \\
\hline & & & & & & $\begin{array}{c}\text { Frozen fresh } \\
\text { samples }\end{array}$ & $\begin{array}{l}\text { Oven-dried } \\
\text { samples }\end{array}$ & \\
\hline 1 & 5.1 & 328 & 353 & $191(100), 179(45), 161(6), 135(66)$ & 3-O-Caffeoylquinic acid & $1.79 \pm 0.03$ & $5.54 \pm 0.03$ & $<0.001$ \\
\hline 2 & 7.2 & 328 & 353 & $191(72), 179(80), 173(100), 161(9), 135(77)$ & 4-O-Caffeoylquinic acid & $1.48 \pm 0.01$ & $2.85 \pm 0.01$ & $<0.001$ \\
\hline 3 & 7.9 & 328 & 353 & 191(100),179(3),161(6),135(4) & 5-O-Caffeoylquinic acid & $27.85 \pm 0.05$ & $51.0 \pm 0.2$ & $<0.001$ \\
\hline 4 & 8.7 & 328 & 381 & $179(35), 161(100), 135(33)$ & $\begin{array}{l}\text { Caffeoyl-2,7-anhydro-3-deoxy- } \\
\text { 2-octulopyranosonic acid }\end{array}$ & $0.22 \pm 0.01$ & $2.82 \pm 0.02$ & $<0.001$ \\
\hline 5 & 9.5 & 320 & 391 & $217(50), 179(38), 135(63)$ & Caffeic acid derivative & $0.20 \pm 0.02$ & $0.84 \pm 0.05$ & $<0.001$ \\
\hline 6 & 19.0 & 354 & 609 & $301(100)$ & Quercetin-3-O-rutinoside & $4.32 \pm 0.01$ & nd & - \\
\hline 7 & 20.2 & 354 & 463 & $301(100)$ & Quercetin-3-O-glucoside & $0.51 \pm 0.01$ & $5.38 \pm 0.04$ & $<0.001$ \\
\hline 8 & 20.7 & 328 & 515 & $353(87), 335(45), 191(41), 179(76), 173(91), 161(17), 135(25)$ & 3,4-O-Dicaffeoylquinic acid & $1.24 \pm 0.04$ & $5.52 \pm 0.03$ & $<0.001$ \\
\hline 9 & 21.0 & 358 & 579 & $301(100)$ & $\begin{array}{l}\text { Quercetin-O-pentosyl- } \\
\text { deoxyhexoside }\end{array}$ & $1.08 \pm 0.02$ & nd & - \\
\hline 10 & 21.3 & 348 & 447 & $285(100)$ & Kaempferol-3-O-glucoside & $2.10 \pm 0.02$ & $0.39 \pm 0.03$ & $<0.001$ \\
\hline 11 & 22.4 & 328 & 515 & $353(90), 335(8), 191(100), 179(89), 173(14), 161(8), 135(46)$ & 3,5-O-Dicaffeoylquinic acid & $18.1 \pm 0.1$ & $49.2 \pm 0.2$ & $<0.001$ \\
\hline 12 & 23.1 & 350 & 447 & $285(100)$ & Kaempferol-O-hexoside & $n d$ & $2.1 \pm 0.1$ & - \\
\hline
\end{tabular}


Results and discussion

\begin{tabular}{|c|c|c|c|c|c|c|c|c|}
\hline 13 & 23.3 & 358 & 433 & $301(100)$ & Quercetin-3-O-xyloside & $2.2 \pm 0.1$ & $2.97 \pm 0.01$ & 0.007 \\
\hline 14 & 24.3 & 350 & 447 & $301(100)$ & Quercetin-3-O-rhamnoside & $9.84 \pm 0.03$ & $9.29 \pm 0.03$ & 0.001 \\
\hline 15 & 25.0 & 328 & 515 & $353(81), 335(3), 191(21), 179(73), 173(100), 135(21)$ & 4,5-O-Dicaffeoylquinic acid & $2.95 \pm 0.04$ & $10.83 \pm 0.05$ & $<0.001$ \\
\hline 16 & 26.4 & 350 & 417 & $285(100)$ & Kaempferol-O-pentoside & $1.35 \pm 0.01$ & $1.03 \pm 0.01$ & $<0.001$ \\
\hline 17 & 27.1 & 350 & 417 & $285(100)$ & Kaempferol-O-pentoside & $0.29 \pm 0.01$ & $0.35 \pm 0.01$ & 0.015 \\
\hline \multirow[t]{4}{*}{18} & 29.0 & 346 & 431 & $285(100)$ & Kaempferol-O-deoxyhexoside & $1.58 \pm 0.02$ & $1.20 \pm 0.02$ & 0.001 \\
\hline & & & & & Total phenolic acid derivatives & $53.8 \pm 0.1$ & $128.5 \pm 0.4$ & $<0.001$ \\
\hline & & & & & Total flavonoids & $23.3 \pm 0.1$ & $22.7 \pm 0.2$ & 0.029 \\
\hline & & & & & Total phenolic compounds & $77.1 \pm 0.2$ & $151 \pm 1$ & $<0.001$ \\
\hline
\end{tabular}




\subsubsection{Antioxidant activity}

Figures 17 and 18 show the results obtained in the antioxidant activity evaluation of $S$. rebaudiana extracts, measured by the DPPH radical scavenging activity (RSA) and reducing power (RP) assays, respectively. The extracts from oven-dried samples gave higher RSA and RP (i.e., lower $\mathrm{EC}_{50}$ values of $22.87 \mu \mathrm{g} / \mathrm{mL}$ and $28.79 \mu \mathrm{g} / \mathrm{mL}$, respectively) than those of frozen fresh samples $(50.66 \mu \mathrm{g} / \mathrm{mL}$ and $39.73 \mu \mathrm{g} / \mathrm{mL})$. These results do not coincide with those obtained by other authors (Pinela et al., 2011), that reported a higher antioxidant activity in frozen fresh samples than in dried material of four shrubby flowering plants from the Cytisus and Genista genera widely used in folk medicine. However, our results are in line with the contents of phenolic compounds observed in both samples, once the extract of the oven-dried samples possessed higher concentration of total phenolic compounds (Table 2), suggesting their relationship with the antioxidant capacity of stevia leaves. Other authors have reported the high potential of $S$. rebaudiana leaves as a natural antioxidant, with associated health benefits (Xi et al 1998; Tadhani et al., 2007; Jahan et al 2010; Kim et al 2011).

Stevia rebaudiana is widely known for its natural sweeteners content, although this plant could also be considered as a good source of antioxidants, such as phenolic compounds. However, appropriate methodologies have to be applied to preserve the chemical constituents of $S$. rebaudiana. The obtained results revealed that oven-dried samples showed higher antioxidant activity and phenolic compounds contents than frozen fresh samples, whereas these latter possessed higher levels of tocopherols and free sugars. Overall, it is very important to establish suitable conditions to cultivate S. rebaudiana in order to standardize its chemical composition, but not least important is the preservation process selected. 


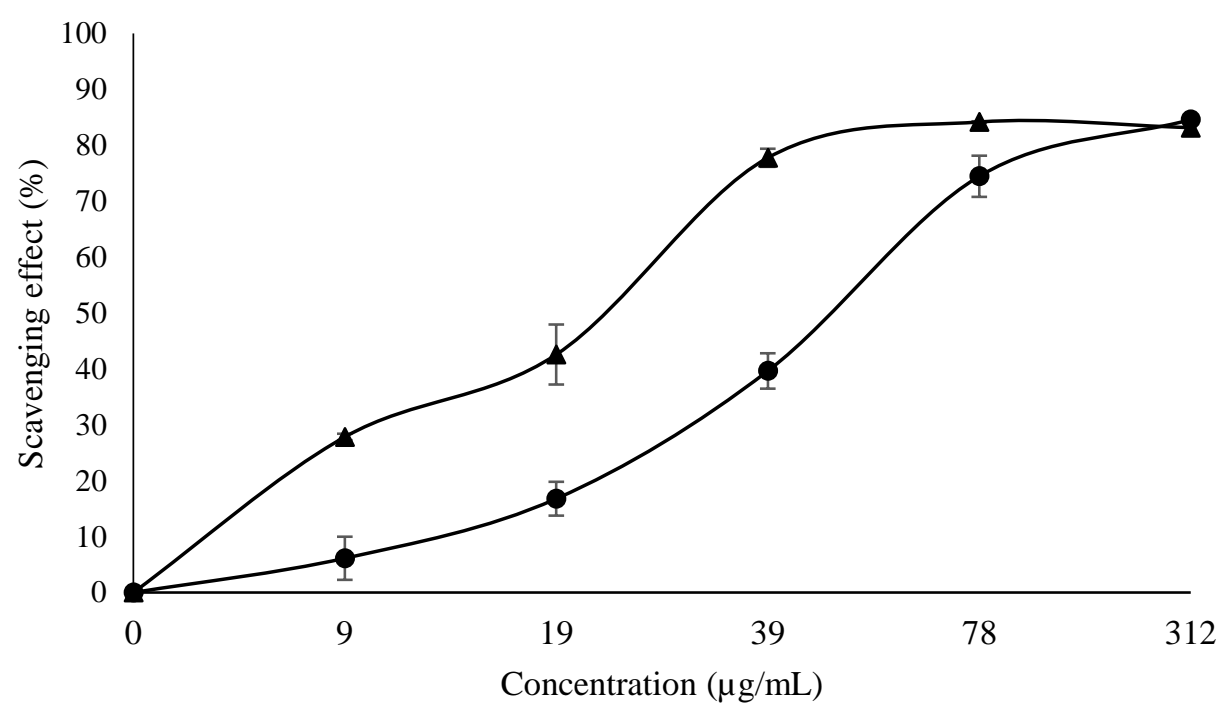

Figure 17. Plot of the percentages of scavenging activity of DPPH radicals in extracts of frozen fresh ( $\rightarrow-$ ) and oven-dried samples ( $\rightarrow$ ) -of Stevia rebaudiana against extract concentration. $\mathrm{EC}_{50}$ values (extract concentration corresponding to $50 \%$ of DPPH scavenging activity) of $50.66 \pm 3.64 \mu \mathrm{g} / \mathrm{mL}$, for frozen fresh samples, and $22.87 \pm 2.17 \mu \mathrm{g} / \mathrm{mL}$, for oven-dried samples.

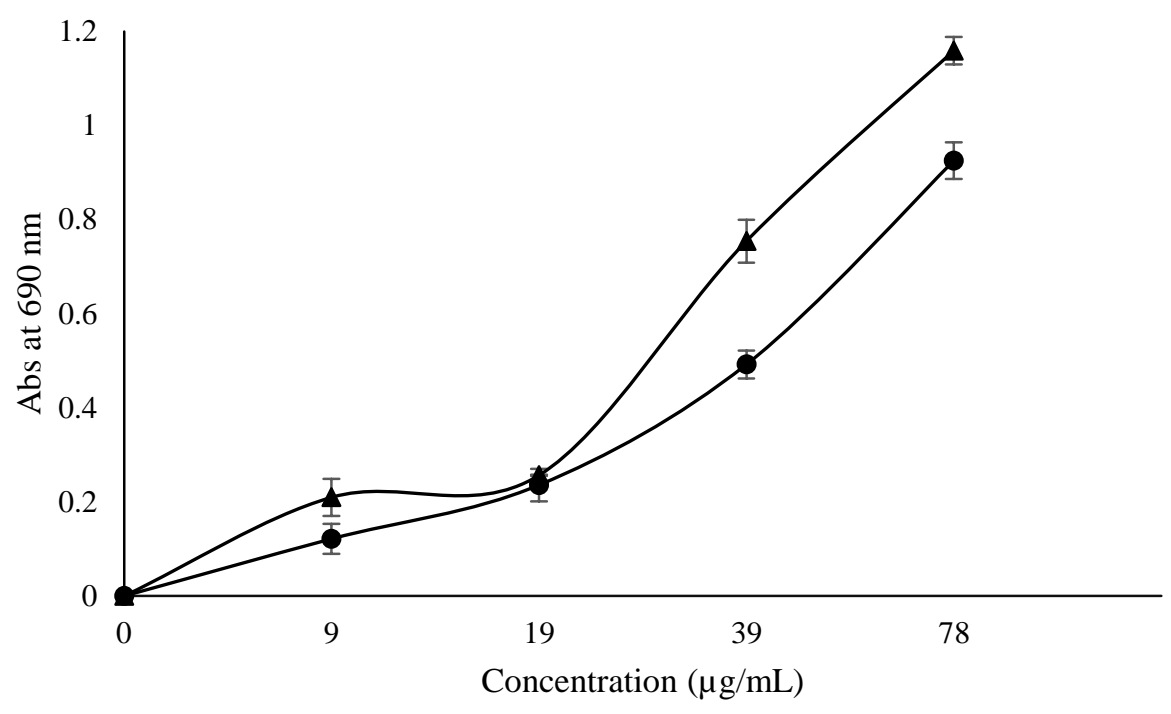

Figure 18. Reducing power of frozen fresh $(\vec{\bullet})$ and oven-dried samples $(\overrightarrow{+})$ of Stevia rebaudiana according to the extract concentration. Higher absorbance indicates higher reducing power. $\mathrm{EC}_{50}$ values (extract concentration giving 0.5 of absorbance) of $39.73 \pm 0.10 \mu \mathrm{g} / \mathrm{mL}$, for frozen fresh samples, and $82.79 \pm$ $0.09 \mu \mathrm{g} / \mathrm{mL}$, for oven-dried samples. 


\subsection{Assessment of the nitrogen fertilization effect on bioactive compounds of}

\section{frozen fresh and dried samples of Stevia rebaudiana Bertoni}

\subsubsection{Free sugars and tocopherols composition}

Tables 3 and 4 show the results obtained for free sugars and tocopherols, respectively, in stevia frozen fresh and dried leaves from plants that were cultivated with different levels of nitrogen fertilization $(0,25,50,100 \mathrm{~kg} \mathrm{~N} / \mathrm{ha}$; N0 to N3, respectively). As for the previous studies, eight sugars were detected in all the studied samples, namely rhamnose, xylose, arabinose + fructose, glucose, sucrose, trehalose and raffinose, being xylose, arabinose + fructose and sucrose the most abundant ones (Table 3). The total sugars contents in the studied samples decreased with the level of $\mathrm{N}$ fertilization, being N0 those that presented the highest content and N3 (100 kg N/ha) the lowest one. This is in agreement with the observations made by Ibrahim et al. (2011) regarding the effects of $\mathrm{N}$ fertilization on primary and secondary metabolites in three varieties of Labisia pumila Blume. Nevertheless, $\mathrm{N} 1$ (25 kg N/ha) presented similar and not significantly different sugar contents as those of N0, so that it could be considered a good compromise $\mathrm{N}$ level for fertilization.

Concerning the process conditions, oven-dried samples presented statistically higher contents in sugars than frozen fresh samples, $13.54 \pm 0.53$ vs. $12.11 \pm 2.04 \mathrm{~g} / 100 \mathrm{~g}$, except for xylose. This result is in disagreement with the previous study (see section 3.1.1; Table $1)$, where significantly higher contents of total sugars were found in frozen (15.04 \pm 0.18 $\mathrm{g} / 100 \mathrm{~g})$ than in dried $(13.17 \pm 0.42 \mathrm{~g} / 100 \mathrm{~g})$ samples. The differences obtained could be due either to a random effect of the conservation process on sugar stability or to differences already existing in the original pant material. Anyway, despite the different statistical results, it should not be expectable that sugars composition undergoes relevant changes either by processing condition (drying methods), nor due to $\mathrm{N}$ application to stevia, because the values obtained in Table 1 and Table 3 are very similar.

Regarding tocopherols composition (Table 4), frozen fresh S. rebaudiana leaves revealed significantly higher content than the dried samples. Thermal sensitivity of tocopherols to relatively high temperatures may explain the obtained results, leading to a consequent reduction of the tocopherols content. Actually, the same observation was already made by the authors in the previous study on frozen fresh (12.70 $\pm 0.10 \mathrm{~g} / 100 \mathrm{~g})$ and oven-dried (6.16 $\pm 0.02 \mathrm{~g} / 100 \mathrm{~g}$ ) samples of $S$. rebaudiana leaves (section 3.1.1; Table 1). 
On the other hand, it was not observed a direct correlation between the different $\mathrm{N}$ rates used for fertilization and tocopherol contents. Nevertheless, although the differences were not statistically significant, the highest concentrations of total tocopherols were found in the samples with higher levels of N fertilization (N2 and N3 samples). In general, comparing the obtained results for free sugars and tocopherols composition, it could be inferred that the drying process has greater impact on the levels of these components than $\mathrm{N}$ fertilization. 


\section{Results and discussion}

Table 3. Sugars contents (g/100 g dry weight) in Stevia rebaudiana Bertoni leaves, under different N substrate rates and processing method (freezing or drying). Within each factor, for $N$ substrate rates and for each Process, and in each column different letters mean significant statistical differences $(p<0.05)$. Lower case letters were used for $N$ substrate rates parameter and capital letters were used for Process.

\begin{tabular}{|c|c|c|c|c|c|c|c|c|c|}
\hline & & Rhamnose & Xylose & Arab.+Fruct. & Glucose & Sucrose & Trehalose & Raffinose & Total \\
\hline \multirow{4}{*}{ Nitrogen } & NO & $0.52 \pm 0.03 a b$ & $6.79 \pm 3.11 a b$ & $2.67 \pm 0.67 c$ & $0.15 \pm 0.12 a$ & $3.02 \pm 1.30 a b$ & $0.42 \pm 0.05 a$ & $0.53 \pm 0.36 a$ & $14.10 \pm 1.01 a$ \\
\hline & $N 1$ & $0.45 \pm 0.09 b c$ & $4.52 \pm 0.50 a$ & $4.10 \pm 0.24 a$ & $0.05 \pm 0.04 b$ & $3.32 \pm 0.32 a$ & $0.34 \pm 0.18 b$ & $0.60 \pm 0.51 a$ & $13.39 \pm 0.78 a b$ \\
\hline & $N 2$ & $0.41 \pm 0.02 c$ & $4.55 \pm 0.34 a$ & $3.51 \pm 0.35 b$ & $0.06 \pm 0.03 b$ & $2.85 \pm 0.81 a b$ & $0.26 \pm 0.06 c$ & $0.63 \pm 0.46 a$ & $12.26 \pm 1.92 b c$ \\
\hline & $N 3$ & $0.54 \pm 0.03 a$ & $3.71 \pm 0.38 b$ & $3.83 \pm 0.41 a$ & $0.04 \pm 0.04 b$ & $2.48 \pm 0.78 b$ & $0.27 \pm 0.05 b c$ & $0.59 \pm 0.37 a$ & $11.46 \pm 1.79 c$ \\
\hline \multirow{2}{*}{ Process } & Frozen fresh & $0.46 \pm 0.08 \mathrm{~A}$ & $5.73 \pm 2.41 A$ & $3.17 \pm 0.73 B$ & $0.13 \pm 0.08 \mathrm{~A}$ & $2.17 \pm 0.55 B$ & $0.29 \pm 0.11 A$ & $0.15 \pm 0.03 B$ & $12.11 \pm 2.04 B$ \\
\hline & Dried & $0.50 \pm 0.07 A$ & $4.17 \pm 0.42 B$ & $3.88 \pm 0.40 \mathrm{~A}$ & $0.02 \pm 0.02 B$ & $3.64 \pm 0.42 \mathrm{~A}$ & $0.33 \pm 0.05 A$ & $0.99 \pm 0.11 A$ & $13.54 \pm 0.53 \mathrm{~A}$ \\
\hline
\end{tabular}

Table 4. Tocopherol contents (mg/100 g dry weight) in Stevia rebaudiana Bertoni leaves, under different $\mathrm{N}$ substrate rates and process processing method (freezing or drying).

\begin{tabular}{cccccc}
\hline \multirow{6}{*}{ Nitrogen } & & $\boldsymbol{\alpha}$-Tocopherol & $\boldsymbol{\gamma}$-Tocopherol & $\boldsymbol{\delta}$-Tocopherol & Total tocopherols \\
& NO & $9.04 \pm 3.52 a$ & $0.21 \pm 0.01 a$ & $0.18 \pm 0.08 \mathrm{~b}$ & $9.42 \pm 3.59 a$ \\
& N1 & $8.50 \pm 2.67 a$ & $0.17 \pm 0.08 a$ & $0.25 \pm 0.07 a b$ & $8.92 \pm 2.81 a$ \\
& N2 & $9.66 \pm 3.15 a$ & $0.18 \pm 0.08 a$ & $0.43 \pm 0.22 a$ & $10.27 \pm 3.45 a$ \\
\multirow{2}{*}{ Process } & Frozen fresh & $11.84 \pm 0.66 \mathrm{~A}$ & $0.24 \pm 0.03 \mathrm{~A}$ & $0.49 \pm 0.23 \mathrm{~A}$ & $12.57 \pm 0.74 \mathrm{~A}$ \\
& Dried & $6.30 \pm 0.39 \mathrm{~B}$ & $0.13 \pm 0.06 \mathrm{~B}$ & $0.19 \pm 0.05 \mathrm{~B}$ & $6.61 \pm 0.40 \mathrm{~B}$ \\
\hline
\end{tabular}

Within each factor, for $N$ substrate rates and for each Process, and in each column different letters mean significant statistical differences $(p<0.05)$. Lower case letters were used for $N$ substrate rates parameter and capital letters were used for Process 


\subsubsection{Phenolic composition}

Table 5 presents the obtained results for the phenolic composition in stevia leaves. Eighteen phenolic compounds were detected, including ten flavonoids (namely quercetin and kaempferol glycosides) and eight hydroxycinnamoyl derivatives. The observed compounds corresponded to the same ones previously identified in stevia leaves (see section 3.1.2; Table 2). Caffeic acid derivatives were the most abundant phenolic compounds in all the tested samples, namely 5-O-caffeoylquinic and 3,5-O-dicaffeoylquinic acids (compounds $\mathbf{3}$ and 11). In relation to flavonoids, quercetin glycosides were more abundant than kaempferol glycosides, with quercetin-3-O-rhamnoside (14) and quercetin-3-O-glucoside (7) as majority derivatives.

Dried samples presented higher levels of phenolic compounds than frozen fresh ones (126.65 vs $85.17 \mathrm{mg} / \mathrm{g}$ extract), even though quercetin-3- $O$-rutinoside and quercetin- $O$-pentosyldeoxyhexoside (compounds $\mathbf{6}$ and $\mathbf{9}$, respectively) were not detected in the dried samples. Moreover, kaempferol- $O$-hexoside (12) was not detected in the frozen fresh samples, and no statistically significant differences were found for compounds 10,14 and 18 between frozen fresh and dry samples. The obtained results are in line with those previously obtained (section 3.1.2), where half concentration of phenolic compounds was found in frozen fresh samples than in oven-dried samples of $S$. rebaudiana leaves. As discussed above, the difference between phenolic contents in both types of processed sample might be explained by greater polyphenol oxidase activity in frozen samples, leading to higher degradation of phenolic acid derivatives, which should be better substrates for the enzyme than flavonoids. $\mathrm{N} 1$ samples (fertilized with $25 \mathrm{~kg} \mathrm{~N} / \mathrm{ha}$ ) showed significantly higher contents of total phenolic compounds than the other ones followed by non-fertilized samples. This aspect may be directly correlated with sugar contents (Table 3). In fact, samples with the highest abundance in phenolic compounds were also those that presented the highest levels of free sugars (i.e. dried processed samples, and N1 and control N0 samples). Similar findings were reported by Ibrahim et al. (2011), who suggested that high sugar contents may exert a more pronounced influence in the synthesis and upregulation of secondary metabolites, and consequently increased total phenolic contents, a view that seems supported by the observation made in the present study. 
Results and discussion

Table 5. Contents of phenolic compounds (mg/g extract) in Stevia rebaudiana Bertoni leaves, under different $\mathrm{N}$ substrate rates and processing method (freezing or drying).

\begin{tabular}{|c|c|c|c|c|c|c|c|c|c|c|c|}
\hline & Phenolic & $1^{A}$ & $2^{A}$ & $3^{A}$ & $4^{B}$ & $5^{B}$ & $6^{C}$ & $7^{D}$ & $8^{A}$ & $9^{D}$ & \\
\hline \multirow{4}{*}{ Nitrogen } & NO & $3.66 \pm 2.17 a$ & $2.16 \pm 0.79 a, b$ & $39.42 \pm 13.37 a$ & $0.99 \pm 1.05 a$ & $0.34 \pm 0.27 a$ & $2.62 \pm 3.02$ & $1.46 \pm 1.14 a$ & $3.32 \pm 2.40 a$ & $0.39 \pm 0.46$ & \\
\hline & $N 1$ & $3.44 \pm 1.69 a$ & $2.14 \pm 0.18 a, b$ & $36.45 \pm 1.26 a$ & $0.66 \pm 0.50 a$ & $0.28 \pm 0.05 a$ & $1.66 \pm 1.92$ & $3.14 \pm 1.12 a$ & $5.23 \pm 1.45 a$ & $0.70 \pm 0.81$ & \\
\hline & $N 2$ & $3.13 \pm 1.14 a$ & $2.69 \pm 1.04 a$ & $39.11 \pm 9.66 a$ & $0.78 \pm 0.53 a$ & $0.31 \pm 0.19 a$ & $0.52 \pm 0.60$ & $2.08 \pm 0.50 a$ & $2.99 \pm 2.07 a$ & $0.22 \pm 0.25$ & \\
\hline & N3 & $3.45 \pm 0.31 a$ & $1.85 \pm 0.62 b$ & $39.10 \pm 4.92 a$ & $0.90 \pm 0.38 a$ & $0.27 \pm 0.08 a$ & $0.10 \pm 0.12$ & $2.38 \pm 0.25 a$ & $3.03 \pm 1.66 a$ & $0.22 \pm 0.26$ & \\
\hline \multirow[t]{3}{*}{ Process } & $\begin{array}{l}\text { Frozen } \\
\text { fresh }\end{array}$ & $2.28 \pm 0.58 B$ & $1.64 \pm 0.28 B$ & $32.64 \pm 3.88 B$ & $0.30 \pm 0.19 B$ & $0.17 \pm 0.05 B$ & $2.45 \pm 2.10$ & $1.62 \pm 0.74 B$ & $2.01 \pm 1.28 B$ & $0.76 \pm 0.42$ & \\
\hline & Dried & $4.57 \pm 0.76 A$ & $2.78 \pm 0.55 \mathrm{~A}$ & $44.40 \pm 6.07 \mathrm{~A}$ & $1.37 \pm 0.34 \mathrm{~A}$ & $0.43 \pm 0.11 \mathrm{~A}$ & $n d$ & $2.92 \pm 0.74 \mathrm{~A}$ & $5.27 \pm 0.82 \mathrm{~A}$ & $n d$ & \\
\hline & Phenolic & $10^{E}$ & $11^{A}$ & $12^{E}$ & $13^{D}$ & $14^{D}$ & $15^{A}$ & $16^{E}$ & $17^{E}$ & $18^{E}$ & Total \\
\hline \multirow{4}{*}{ Nitrogen } & NO & $0.28 \pm 0.02 a$ & $33.62 \pm 17.99 b$ & $0.97 \pm 1.12$ & $0.64 \pm 0.73$ & $4.28 \pm 0.20 b$ & $4.90 \pm 3.14 b$ & $0.53 \pm 0.11 a$ & $0.14 \pm 0.16$ & $0.85 \pm 0.42 a, b$ & $99.70 \pm 1.06 b$ \\
\hline & $N 1$ & $0.26 \pm 0.10 a, b$ & $57.59 \pm 0.96 a$ & $1.88 \pm 2.17$ & $1.32 \pm 1.53$ & $7.71 \pm 0.67 a$ & $9.88 \pm 2.20 a$ & $0.98 \pm 0.47 a$ & $0.62 \pm 0.26$ & $1.98 \pm 1.18 a$ & $133.94 \pm 0.23 a$ \\
\hline & $N 2$ & $0.44 \pm 0.49 a, b$ & $29.57 \pm 14.08 b$ & $1.12 \pm 1.29$ & $0.93 \pm 1.08$ & $4.58 \pm 0.30 b$ & $4.73 \pm 3.50 b$ & $0.52 \pm 0.37 a$ & $0.18 \pm 0.21$ & $0.50 \pm 0.05 b$ & $93.90 \pm 1.75 c$ \\
\hline & N3 & $0.09 \pm 0.09 b$ & $29.32 \pm 10.54 b$ & $0.98 \pm 1.13$ & $1.02 \pm 1.18$ & $4.20 \pm 0.29 b$ & $4.89 \pm 2.73 b$ & $0.34 \pm 0.20 b$ & $0.14 \pm 0.17$ & $0.45 \pm 0.14 b$ & $92.30 \pm 0.02 c$ \\
\hline \multirow[t]{2}{*}{ Process } & $\begin{array}{l}\text { Frozen } \\
\text { fresh }\end{array}$ & $0.17 \pm 0.16 \mathrm{~A}$ & $28.39 \pm 18.26 B$ & $n d$ & $1.96 \pm 0.53$ & $5.38 \pm 1.79 A$ & $3.60 \pm 2.73 B$ & $0.39 \pm 0.22 B$ & $n d$ & $1.31 \pm 1.09 \mathrm{~A}$ & $85.17 \pm 0.57 B$ \\
\hline & Dried & $0.37 \pm 0.31 A$ & $46.66 \pm 7.81 \mathrm{~A}$ & $*$ & $2.47 \pm 0.81 *$ & $5.00 \pm 1.37 \mathrm{~A}$ & $8.59 \pm 1.98 A$ & $0.79 \pm 0.40 A$ & $0.44 \pm 0.25$ & $0.58 \pm 0.25 A$ & $126.65 \pm 2.11 \mathrm{~A}$ \\
\hline
\end{tabular}

1) 3-O-Caffeoylquinic acid; 2) 4-O-caffeoylquinic acid; 3) 5-O-caffeoylquinic acid;4) caffeoyl-2,7-anhydro-3-deoxy-2-octulopyranosonic acid; 5) caffeic acid derivative; 6) quercetin-3-O-rutinoside; 7) quercetin-3-Oglucoside; 8) 3,4-O-dicaffeoylquinic acid; 9) quercetin-O-pentosyl-deoxyhexoside; 10) kaempferol-3-O-glucoside; 11) 3,5-O-dicaffeoylquinic acid; 12) kaempferol-O-hexoside; 13) quercetin-3-O-xyloside; 14) quercetin3-O-rhamnoside; 15) 4,5-O-dicaffeoylquinic acid; 16) kaempferol-O-pentoside; 17) kaempferol-O-pentoside; 18) kaempferol-O-deoxyhexoside. Within each factor, for $N$ substrate rates and for each Process, and in each column different letters mean significant statistical differences $(p<0.05)$. Lower case letters were used for $N$ substrate rates parameter and capital letters were used for Process. nd- not detected; *In dried samples, peak 12 and 13 were not well separated, being quantified as a mixture of both compounds. Calibration curves: A: chlorogenic acids $\left(y=168823 x-161172 ; R^{2}=0.999\right) ; B:$ caffeic acid ( $\left.y=388345 x+406369 ; R^{2}=0.999\right) ; C$ : quercetin-3-O-rutinoside ( $\left.y=13343 x+76751 ; R^{2}=0.999\right)$, D: quercetin-3-O-glucoside $\left(y=34843 x-160173 ; R^{2}=0.999\right) ;$ E: kaempferol-3-O-rutinoside ( $\left.y=41843 x+220192 ; R^{2}=0.999\right)$. 


\subsubsection{Antioxidant activity}

Table 6 shows the results obtained in the assessment of the in vitro antioxidant potential of S. rebaudiana leaves, under different $\mathrm{N}$ substrate rates and processing method (freezing or drying). Two different methods were used to determine the antioxidant activity of stevia samples, namely DPPH radical scavenging activity (RSA) and reducing power (RP). In general, oven-dried samples revealed the best antioxidant values $(\mathrm{RSA}=26.39 \pm 3.20$ $\mathrm{mg} / \mathrm{mL} ; \mathrm{RP}=27.64 \pm 1.83 \mathrm{mg} / \mathrm{mL}$ ). These results are in agreement with those previously obtained (section 3.1.1), in which oven-dried samples evidenced higher antioxidant capacity than frozen fresh samples.

$\mathrm{N} 2\left(\mathrm{EC}_{50}=30.06 \pm 4.33 \mathrm{mg} / \mathrm{mL}\right)$ and $\mathrm{N} 1\left(\mathrm{EC}_{50}=31.21 \pm 1.63 \mathrm{mg} / \mathrm{mL}\right)$ samples presented the best results for RSA and RP, respectively, followed in each case by N0 and N3 samples. Thus, the measured antioxidant potential of stevia samples presented the following decreasing order: RSA: N2 > N0 > N3 > N1; RP: N1 > N3 > N0 > N2.

A positive correlation was found when comparing the results obtained for the antioxidant activity with the phenolic compounds content, especially for the RP assay. Nevertheless, the degree of this correlation seems related to the type of antioxidant assay applied and, therefore, linked to the different mechanisms of action of each assay. Regarding the conservation process, samples with greater abundance in phenolic compounds (i.e., dried processed samples) revealed the highest antioxidant activity. On the other hand, and in a general manner, dried samples were at the same time those that presented the highest antioxidant potential, contents in free sugars and phenolic compounds, and the lowest values of tocopherols. On the contrary, samples containing the highest content in tocopherols (frozen fresh samples) were those that presented the lowest RP and phenolic compounds contents, but higher RSA, thus, the higher levels of tocopherols could be related to the higher RSA. These observations seem to suggest that the antioxidant ability of stevia samples is influenced by the both phenolic compounds and tocopherols, although in different extents depending on the mechanism of action of the applied assay.

Concerning samples obtained under different $\mathrm{N}$ substrate rates, significant composition differences were observed between the studied samples (mainly in terms of tocopherols and phenolic compounds). Moreover, better values of antioxidant activity were obtained for fertilized samples (i.e., N2 for RSA, and N1 and N3 for RP) than for the non-fertilized ones N0. In this sense, it seems that $\mathrm{N}$ fertilization might provide some improvement on the bioactive potential of stevia leaves. 
Correlation factors were obtained between the antioxidant activity assays and phenolic compounds (individual compounds and total contents), using a Pearson's correlation analysis, because the normality was verified through a Shapiro-Wilk test. The correlation of all the antioxidant assays (DPPH scavenging activity and reducing power) and phenolic compounds are presented in Table 7. In general, most compounds showed correlations statistically significant with the antioxidant activity assays.

Quercetin-3-O-rutinoside (compound 6) presented the most significant correlation with all antioxidant activities tested. Nonetheless, the total flavonoid content correlated worse with the antioxidant activity than total phenolic acids, which might be due to the higher concentration of these latter in the samples. Total phenolic compounds also presented an excellent correlation factor. The major individual phenolic compound (5-O-caffeoylquinic acid) also had a high correlation with the antioxidant activity assays, showing a variation between -0.860 and -0.815 . Overall, total phenolic acids and total phenolic compounds showed statistically significant correlations with both the assays, with the exception of quercetin-3-O-rhamnoside, kaempferol- $O$-pentoside and kaempferol- $O$-deoxyhexoside (compounds 14, 17 and 18), which were the only ones that did not present statistically significant correlation with the antioxidant assays ( $p$-values $>0.05$ ).

Table 6. Antioxidant activity (expressed in $\mathrm{EC}_{50}$ values, $\mathrm{mg} / \mathrm{mL}$ of extract) of Stevia rebaudiana Bertoni leaves, under different $\mathrm{N}$ substrate rates and processing method (freezing or drying).

\begin{tabular}{llll}
\hline & & DPPH scavenging activity & Reducing power \\
\hline \multirow{2}{*}{ Nitrogen } & NO & $36.76 \pm 14.59 \mathrm{ab}$ & $34.26 \pm 5.63 \mathrm{ab}$ \\
& $N 1$ & $40.82 \pm 10.45 \mathrm{a}$ & $31.21 \pm 1.63 \mathrm{~b}$ \\
& $\mathrm{~N} 2$ & $30.06 \pm 4.33 \mathrm{~b}$ & $35.66 \pm 9.93 \mathrm{a}$ \\
\multirow{2}{*}{ Process } & Frozen fresh & $46.40 \pm 7.57 \mathrm{~A}$ & $32.14 \pm 6.43 \mathrm{ab}$ \\
& Dried & $26.39 \pm 3.20 \mathrm{~B}$ & $38.99 \pm 4.62 \mathrm{~A}$ \\
\hline
\end{tabular}

Within each factor, for $N$ substrate rates and for each Process, and in each column different letters mean significant statistical differences $(p<0.05)$. Lower case letters were used for $N$ substrate rates parameter and capital letters were used for Process 
Results and discussion

Table 7. Correlation coefficients of phenolic compounds with in vitro antioxidant activity of Stevia rebaudiana Bertoni leaves, under different N substrate rates and processing method (freezing or drying).

\begin{tabular}{|c|c|c|c|c|c|}
\hline \multirow[b]{2}{*}{ Peaks } & \multirow[b]{2}{*}{ Compounds } & \multicolumn{2}{|c|}{ DPPH scavenging activity } & \multicolumn{2}{|l|}{ Reducing power } \\
\hline & & Correlation factor & $p$-value & Correlation factor & p-value \\
\hline 1 & 3-O-Caffeoylquinic acid & -0.716 & $<0.001$ & -0.688 & $<0.001$ \\
\hline 2 & 4-O-Caffeoylquinic acid & -0.834 & $<0.001$ & -0.759 & $<0.001$ \\
\hline 3 & 5-O-Caffeoylquinic acid & -0.860 & $<0.001$ & -0.815 & $<0.001$ \\
\hline 4 & Caffeoyl-2,7-anhydro-3-deoxy-2-octulopyranosonic acid & -0.807 & $<0.001$ & -0.746 & $<0.001$ \\
\hline 5 & Caffeic acid derivative & -0.891 & $<0.001$ & -0.840 & $<0.001$ \\
\hline 6 & Quercetin-3-O-rutinoside & 0.989 & $<0.001$ & 0.944 & $<0.001$ \\
\hline 7 & Quercetin-3-O-glucoside & -0.606 & 0.002 & -0.617 & 0.001 \\
\hline 8 & 3,4-O-Dicaffeoylquinic acid & -0.894 & $<0.001$ & -0.853 & $<0.001$ \\
\hline 9 & Quercetin-O-pentosyl-deoxyhexoside & -0.872 & 0.008 & -0.806 & 0.002 \\
\hline 10 & Kaempferol-3-O-glucoside & 0.538 & 0.021 & 0.526 & 0.025 \\
\hline 11 & 3,5-O-Dicaffeoylquinic acid & -0.794 & $<0.001$ & 0.740 & $<0.001$ \\
\hline 12 & Kaempferol-O-hexoside & 0.891 & $<0.001$ & 0.852 & $<0.001$ \\
\hline 13 & Quercetin-3-O-xyloside & -0.719 & 0.008 & -0.616 & 0.033 \\
\hline 14 & Quercetin-3-O-rhamnoside & -0.189 & 0.377 & -0.194 & 0.364 \\
\hline 15 & 4,5-O-Dicaffeoylquinic acid & -0.809 & $<0.001$ & -0.794 & $<0.001$ \\
\hline 16 & Kaempferol-O-pentoside & 0.921 & $<0.001$ & 0.713 & $<0.001$ \\
\hline 17 & Kaempferol-O-pentoside & -0.078 & 0.759 & -0.176 & 0.486 \\
\hline \multirow[t]{4}{*}{18} & Kaempferol-O-deoxyhexoside & 0.143 & 0.572 & 0.217 & 0.388 \\
\hline & Total phenolic acids & -0.925 & $<0.001$ & -0.872 & $<0.001$ \\
\hline & Total flavonoids & -0.694 & 0.017 & -0.690 & 0.019 \\
\hline & Total phenolic compounds & -0.807 & $<0.001$ & -0.768 & $<0.001$ \\
\hline
\end{tabular}




\subsection{Stevia rebaudiana Bertoni obtained by in vitro culture with kinetin: focus on chemical composition and antioxidant compounds}

\subsubsection{In vitro culture of Stevia rebaudiana}

Explants for in vitro micropropagation were obtained from plants of a commercial clone of $S$. rebaudiana grown in the field; stems with nodes were separated for inoculation and sterilized as described in section 2.3 of Material and Methods. The percentage of explant survival after sterilization was $95 \%$. In the medium containing kinetin, from an initial single explant, 12-14 new shoots were obtained, while in the medium without kinetin only 3 to 4 were observed. Also, the multiplication rate was higher in the presence of kinetin $(3 \mathrm{x}$ higher than the in vitro culture without kinetin), despite presenting a lower height growth (Figure 19). On the other hand, in the medium without kinetin, fewer new shoots were counted, although they were more developed in height in relation to the pre-existing ones. In fact, being a cytokinins a phytoregulator responsible for cell multiplication, the present findings would be expected. As already reported cytokinins play an important role as regulatory factors of plant meristem activity and morphogenesis, since they act in vital molecular processes of all plant (Werner et al., 2001). In fact, the development of in vitro root systems occurs spontaneously, also allowing to obtain complete plants in a vegetative state. Moreover, through increasing cell division, it is possible to obtain a greater number of plants for subsequent tests, and at the same time to favor a closer morphological and physiological similarity with ex vitro counterparts. 


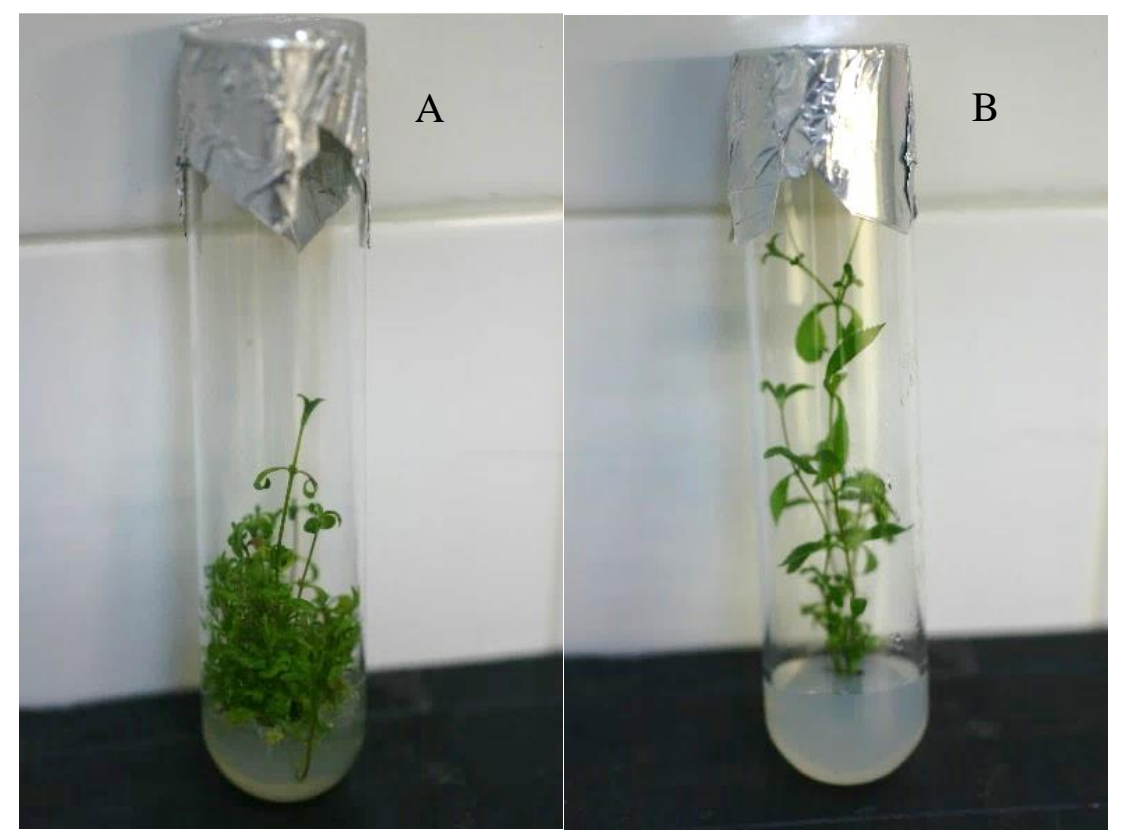

Figure 19. In vitro cultured S. rebaudiana with kinetin (A) and without kinetin (B).

\subsubsection{Free sugars and tocopherols}

Table 8 shows the obtained results regarding contents of tocopherols and free sugars for $S$. rebaudiana leaves cultured in vitro. Samples grown without kinetin presented higher abundance in $\alpha$-tocopherol, $\gamma$-tocopherol, $\delta$-tocopherol, and total tocopherols than those cultured in the presence of kinetin (Table 8, Figure 20A). The same tocopherol profile was previously found in the leaves of $S$. rebaudiana grown in the field and submitted to different conservation conditions (see sections 3.1.1 and 3.2.1), although greater tocopherol contents were obtained in the samples cultivated in vitro. To the best of our knowledge, this is the first report on the influence of kinetin on the tocopherol composition in S. rebaudiana. Tounekti et al. (2011) performed an experiment aiming at determining the effect of kinetin on antioxidant compounds (including tocopherols) in Salvia officinalis. Those authors observed an increase in tocopherols content over time using kinetin $(10 \mu \mathrm{M})$, but only under stress conditions, whereas no significant differences were observed in samples that were not cultured under stress. Anyway, the fact that no increase was found in the tocopherols levels in our assays could be attributed to the relatively low kinetin concentration used $(0.5 \mathrm{mg} / \mathrm{L})$.

In our previous studies, it has been found that the final tocopherols content was affected not only by processing conditions, but also by nitrogen concentration used for medium supplementation (see section 3.2.1). Thus, frozen fresh samples revealed higher contents in 
tocopherols than oven-dried samples, while tocopherols varied according to nitrogen rates used, being the highest content in tocopherols observed in stevia samples fertilized with the higher nitrogen concentrations.

In relation to free sugars content, stevia samples cultured with kinetin evidenced higher concentration in fructose, glucose, raffinose, and total free sugars than those grown without kinetin (Table 8, Figure 20B). No significant differences were observed for trehalose ( $\mathrm{p}=$ $0.019)$ and sucrose $(\mathrm{p}=0.793)$, while no xylose, rhamnose, and arabinose were now detected contrary to the results obtained previously in leaves of $S$. rebaudiana submitted to different conservation process and fertilization conditions (see sections 3.1.1 and 3.2.1), where xylose was in turn the majority sugar detected. On the other hand, as for tocopherols, greater contents of total sugars were found in the samples cultivated in vitro than in those grown in the field.

Ahmed \& Khalid (2017) evaluating the kinetin capacity to increase nutrients and other chemical constituents in Nigella sativa L., stated a close dependency between sugar accumulation and the kinetin concentration applied. The highest concentration of soluble sugars was obtained at $20 \mathrm{mg} / \mathrm{L}$ of kinetin, while no significant differences were observed at $10 \mathrm{mg} / \mathrm{L}$; however, from 30 to $40 \mathrm{mg} / \mathrm{L}$, sugars content decreased with the increase of kinetin concentration. As far as we know, there are no reports regarding kinetin influence on sugar composition in stevia.

Table 8. Composition in tocopherols and free sugars of $S$. rebaudiana leaves cultivated in vitro $(\mathrm{n}=9$, mean \pm $\mathrm{SD})$.

\begin{tabular}{cccc}
\hline Compounds & In vitro culture with kinetin & In vitro culture without kinetin & $\begin{array}{c}\text { t- Student test } \\
\text { p-value }\end{array}$ \\
\hline$\alpha$-Tocopherol & $21.4 \pm 0.4$ & $27.77 \pm 0.04$ & $<0.001$ \\
$\gamma$-Tocopherol & $0.10 \pm 0.01$ & $0.18 \pm 0.01$ & $<0.001$ \\
$\delta$-Tocopherol & $1.6 \pm 0.1$ & $2.86 \pm 0.09$ & $<0.001$ \\
Total $($ mg/lo0 $\mathrm{g} d w$ ) & $23.0 \pm 0.5$ & $30.8 \pm 0.1$ & $<0.001$ \\
\hline Fructose & $1.81 \pm 0.06$ & $1.2 \pm 0.1$ & 0.001 \\
Glucose & $1.90 \pm 0.08$ & $1.59 \pm 0.08$ & 0.002 \\
Sucrose & $3.1 \pm 0.3$ & $3.1 \pm 0.2$ & 0.793 \\
Trehalose & $0.68 \pm 0.02$ & $0.54 \pm 0.01$ & $<0.001$ \\
Raffinose & $0.43 \pm 0.05$ & $0.52 \pm 0.02$ & 0.019 \\
Total $(\mathrm{g} / 100 \mathrm{~g} d w)$ & $8.0 \pm 0.6$ & $6.9 \pm 0.4$ & $<0.001$ \\
\hline
\end{tabular}




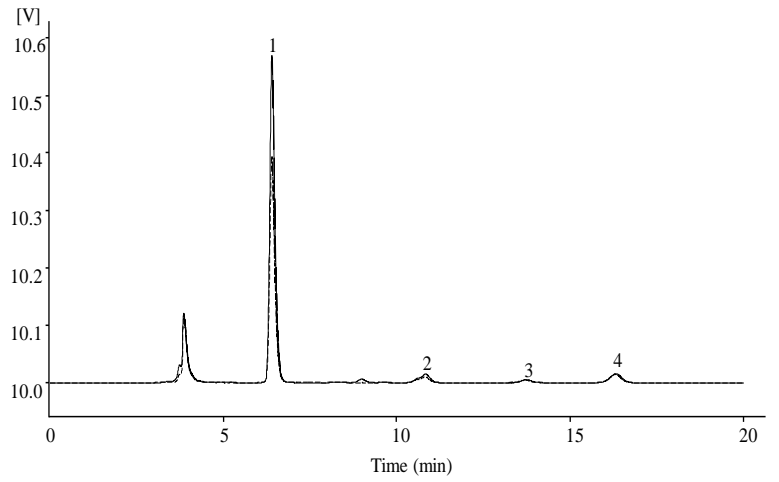

A

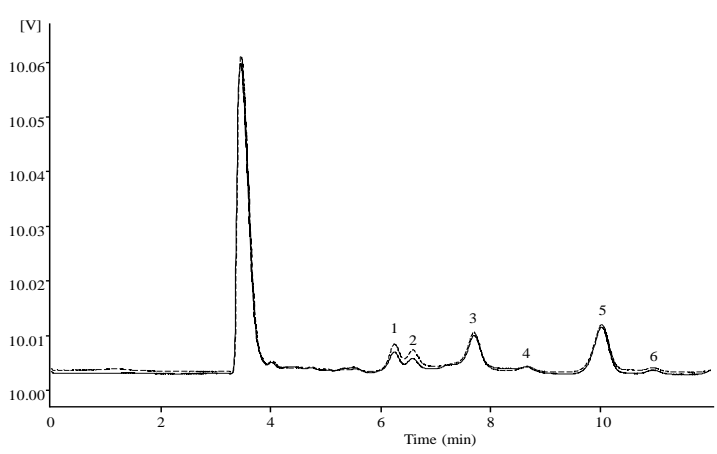

B

Figure 20. HPLC profiles of tocopherols (A) and free sugars (B) in S. rebaudiana leaves cultivated in vitro without (-) and with kinetin (---). (A) 1- $\alpha$-tocopherol, 2- $\gamma$-tocopherol, 3- $\delta$-tocopherol, 4- Tocol (IS); (B) 1- fructose, 2- glucose, 3- sucrose, 4- treahalose, 5- melezitose (IS), 6- raffinose.

\subsubsection{Phenolic compounds}

Figure 21 and Table 9 show the results obtained for phenolic compounds identification and individual quantification. Nine phenolic compounds were identified in the methanol:water extracts being all of them chlorogenic acids, namely 3-O-caffeoylquinic acid (1), 4-Ocaffeoylquinic acid (2), 5-O-caffeoylquinic acid (3), cis 3,4-O-dicaffeoylquinic acid (4), trans 3,4-O-dicaffeoylquinic acid (5), cis 3,5-O-dicaffeoylquinic acid (6), trans 3,5-Odicaffeoylquinic acid (7), cis 4,5-O-dicaffeoylquinic acid (8), and trans 4,5-Odicaffeoylquinic acid (9). These compounds have been previously identified in stevia samples obtained from field-grown plants (sections 3.1.2 and 3.2.2) even though in those analyses only the trans isomers of the acids were detected. The identity of the cis derivatives was confirmed by submitting hydroxycinnamic acids to UV irradiation (366 nm, $24 \mathrm{~h}$ ), leading to partial isomerization of the double bound in their aliphatic chain, which allows confirming their chromatographic elution before the corresponding trans derivatives. The observation that higher concentrations exist of the cis forms of dicaffeoylquinic acids than those of the more usual trans isomers is of particular interest, and it could be attributed to the growth of the plants under light bulbs instead of open-air. Another relevant observation in the phenolic profiles of the in vitro cultured plants was that no significant levels of flavonoids were detected. Furthermore, the concentrations of phenolic compounds in these samples are much lower than those found in the extracts of the leaves of $S$. rebaudiana grown in the field (compare results shown in the Table 9 with those in Tables 2 and 5 in sections 3.1.3 and 3.2.3). These important differences between the phenolic composition could 
explain the lower antioxidant activity observed for the in vitro cultured plants compared to those grown in the field (see results in section 3.3.4).

Samples cultured with kinetin presented a lower concentration in total phenolic compounds and in compounds 3, 5, 6, and 7 than those cultured without kinetin. Otherwise, compounds 1 and 2 were more abundant in samples cultured in the presence of kinetin, while no significant differences were observed for compounds 4, 8, and 9. Among the compounds analyzed in the present study, the final concentration increased in only two caffeoylquinic acids (1 and 2). Radić et al. (2016) studied the influence of two plant growth regulators (indole-3-acetic acid and indole-3-butyric acid) on secondary metabolites production (i.e., total phenolics and flavonoids content) in $S$. rebaudiana leaves. Contrary to our observations, those authors found a positive effect from both plant growth regulators on the accumulation of these secondary metabolites, being the improvement observed dependent of the concentration applied: the highest effect was stated using indole-3-butyric acid at 1.5 $\mathrm{mg} / \mathrm{L}$. Besides that, Radić et al. (2016) also found that the final content in secondary metabolites was also highly affected by the $\mathrm{pH}$ value of the medium, with total phenolics and flavonoids tending to decrease with the increasing $\mathrm{pH}$ levels. According to this observation, it might be envisaged that it would be feasible to modulate the effects of kinetin on the phenolic composition in stevia leaves by modifying the culture conditions (i.e, $\mathrm{pH}$ value). 
A

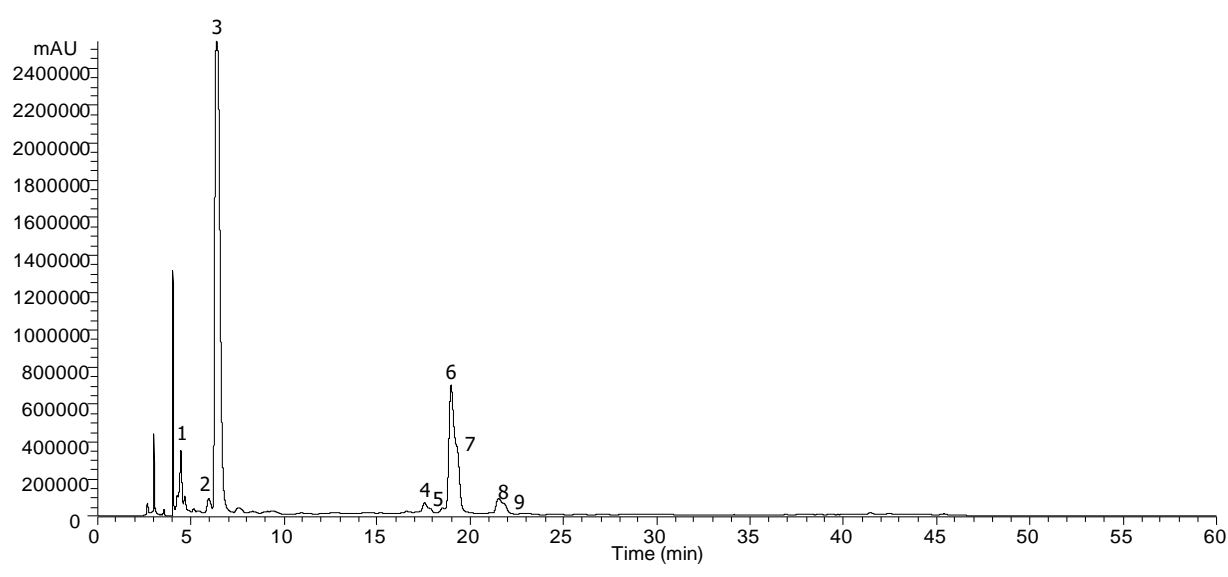

B

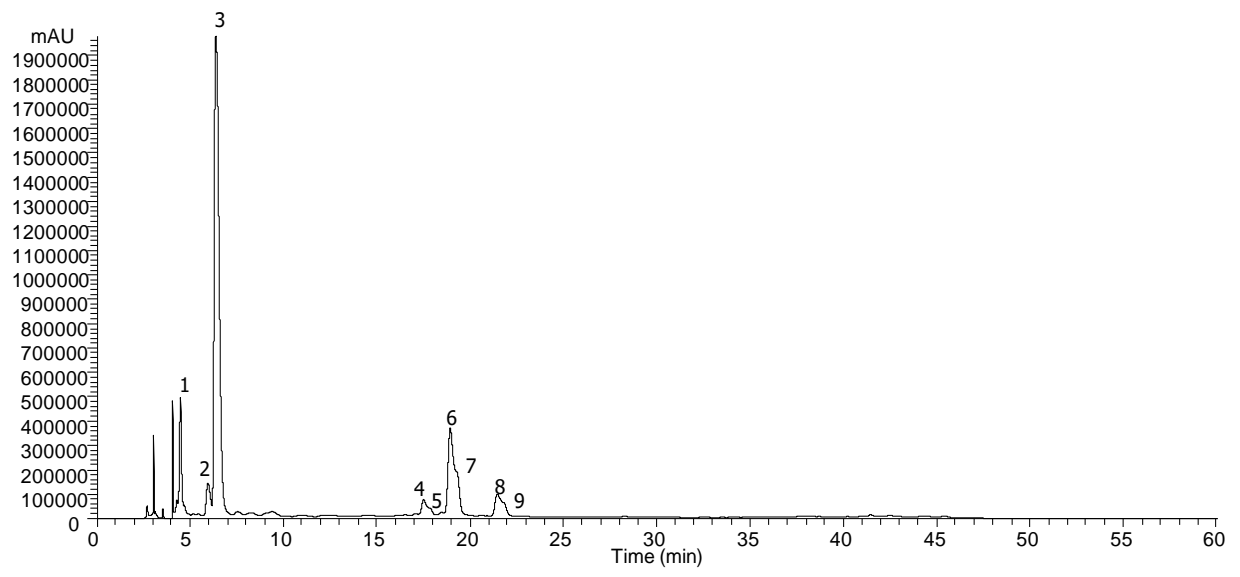

Figure 21. HPLC phenolic profiles of $S$. rebaudiana leaves cultivated in vitro without kinetin (A) and with kinetin (B), recorded at $330 \mathrm{~nm}$. 
Results and discussion

Table 9. Phenolic compounds identification and quantification in S. rebaudiana leaves cultivated in vitro $(\mathrm{n}=9$, mean $\pm \mathrm{SD})$

\begin{tabular}{|c|c|c|c|c|c|c|c|c|}
\hline \multirow[t]{2}{*}{ Compounds } & \multirow{2}{*}{$\begin{array}{l}\text { Rt } \\
(\min )\end{array}$} & \multirow{2}{*}{$\begin{array}{l}\lambda_{\max } \\
(n m)\end{array}$} & \multirow{2}{*}{$\begin{array}{l}\text { Pseudomolecular } \\
\text { ion } \\
{[M-H]^{-}(\mathrm{m} / \mathrm{z})}\end{array}$} & \multirow{2}{*}{$\begin{array}{l}M S^{2} \\
(\mathbf{m} / \mathbf{z})\end{array}$} & \multirow{2}{*}{ Tentative identification } & \multicolumn{2}{|c|}{ Quantification (mg/g extract) } & \multirow{2}{*}{$\begin{array}{l}\text { t-Student } \\
\text { test p- } \\
\text { value }\end{array}$} \\
\hline & & & & & & $\begin{array}{l}\text { In vitro culture } \\
\text { with kinetin }\end{array}$ & $\begin{array}{l}\text { In vitro culture } \\
\text { without kinetin }\end{array}$ & \\
\hline 1 & 4.5 & 328 & 353 & $191(100), 179(45), 161(6), 135(66)$ & 3-O-Caffeoylquinic acid & $3.33 \pm 0.08$ & $2.44 \pm 0.01$ & $<0.001$ \\
\hline 2 & 5.9 & 328 & 353 & $191(72), 179(80), 173(100), 161(9), 135(77)$ & 4-O-Caffeoylquinic acid & $1.85 \pm 0.01$ & $1.18 \pm 0.01$ & $<0.001$ \\
\hline 3 & 6.4 & 328 & 353 & $191(100), 179(3), 161(6), 135(4)$ & 5-O-Caffeoylquinic acid & $23.63 \pm 0.05$ & $35.91 \pm 0.02$ & $<0.001$ \\
\hline 4 & 17.5 & 328 & 515 & $353(87), 335(45), 191(41), 179(76), 173(91), 161(17), 135(25)$ & cis 3,4-O-Dicaffeoylquinic acid & $1.17 \pm 0.06$ & $1.11 \pm 0.07$ & 0.202 \\
\hline 5 & 17.8 & 328 & 515 & $353(87), 335(45), 191(41), 179(76), 173(91), 161(17), 135(25)$ & trans 3,4-O-Dicaffeoylquinic acid & $6.4 \pm 0.2$ & $11.6 \pm 0.3$ & $<0.001$ \\
\hline 6 & 18.9 & 328 & 515 & $353(90), 335(8), 191(100), 179(89), 173(14), 161(8), 135(46)$ & cis 3,5-O-Dicaffeoylquinic acid & $2.0 \pm 0.1$ & $1.8 \pm 0.1$ & 0.048 \\
\hline 7 & 19.3 & 328 & 515 & $353(90), 335(8), 191(100), 179(89), 173(14), 161(8), 135(46)$ & trans 3,5-O-Dicaffeoylquinic acid & $38.4 \pm 0.5$ & $54.0 \pm 0.4$ & $<0.001$ \\
\hline 8 & 21.5 & 328 & 515 & $353(81), 335(3), 191(21), 179(73), 173(100), 135(21)$ & cis 4,5-O-Dicaffeoylquinic acid & $3.33 \pm 0.08$ & $2.44 \pm 0.01$ & $<0.001$ \\
\hline \multirow[t]{2}{*}{9} & 21.8 & 328 & 515 & $353(81), 335(3), 191(21), 179(73), 173(100), 135(21)$ & trans 4,5-O-Dicaffeoylquinic acid & $1.85 \pm 0.01$ & $1.18 \pm 0.01$ & $<0.001$ \\
\hline & & & & & Total phenolic compounds & $23.63 \pm 0.05$ & $35.91 \pm 0.02$ & $<0.001$ \\
\hline
\end{tabular}




\subsubsection{Antioxidant activity}

The results of the antioxidant activity of the methanol:water extracts prepared from in vitro cultured stevia are shown in Table 10. Samples cultured without kinetin revealed higher radical scavenging activity and reducing power than those cultured in the presence of kinetin. Nevertheless, the antioxidant potential of all the in vitro cultured samples was lower than those obtained for the extracts of leaves of field-grown $S$. rebaudiana plants (compare with results discussed in sections 3.1.3 and 3.2.3), which might be explained by the lower contents of phenolic compounds also present in the in vitro samples. Contrary to our observations, Tounekti et al. (2011), using leaf extracts from Salvia officinalis grown with kinetin under control and stress conditions, observed a significant improvement in the antioxidant activity, although only when kinetin was used under stress conditions, as also occurred for tocopherol levels. On the other hand, Radić et al. (2016), studying the influence of different plant growth regulators (i.e., indole-3-acetic and indole-3-butyric acids) on the antioxidant capacity of in vitro propagated S. rebaudiana, observed that the antioxidant potential of stevia tissues (leaves, callus and roots) was significantly and differentially affected by the distinct plant hormones and medium $\mathrm{pH}$ values assayed. It was found that the antioxidant capacity evidenced by a specific plant growth regulator was dependent on the concentration used; thus, the antioxidant activity increased through reducing indole-3-acetic acid concentration, and increased with the increase in indole-3-butyric acid (Radić et al., 2016;

Khalil et al., 2016). Those authors assessed the synergistic effects of polyamines and plant growth regulators on in vitro $S$. rebaudiana propagation, stevioside production and antioxidant capacity, and highlighted that the antioxidant capacity of in vitro cultures was positively regulated through combining polyamines and cytokinin rather than biomass accumulation. Thus, it would be interesting to assess the effects of other variables (e.g., different stress conditions, applied compounds or medium $\mathrm{pH}$ ) and/or plant growth regulators together with kinetin. 
Table 10. Antioxidant activity (expressed in $\mathrm{EC}_{50}$ values, $\mathrm{mg} / \mathrm{mL}$ of extract) of Stevia rebaudiana leaves cultivated in vitro $(\mathrm{n}=9$, mean $\pm \mathrm{SD})$.

\begin{tabular}{lccc}
\hline & $\begin{array}{c}\text { In vitro culture with } \\
\text { kinetin }\end{array}$ & $\begin{array}{c}\text { In vitro culture } \\
\text { without kinetin }\end{array}$ & $\begin{array}{c}\text { t-Students test } \\
\text { p-value }\end{array}$ \\
\hline DPPH scavenging activity & $357 \pm 27$ & $191 \pm 6$ & $<0.001$ \\
Reducing power & $200 \pm 17$ & $70.1 \pm 0.7$ & $<0.001$ \\
\hline
\end{tabular}

$E_{50}$ values correspond to the sample concentration achieving $50 \%$ of antioxidant activity or 0.5 of absorbance in reducing power assay. Trolox $E_{50}$ values: $42 \mu \mathrm{g} / \mathrm{mL}$ (DPPH scavenging activity) and $41 \mu \mathrm{g} / \mathrm{mL}$ (reducing power).

Based on the obtained results and literature available, through comparing in vitro cultures of stevia with field-grown ones, it seems that standard cultivated plants (wild, commercial, regional) have higher antioxidant capacity than those from in vitro cultures.

The profiles of antioxidant components and their concentrations in the studied samples, as determined by the cultivation and processing conditions, must contribute to the antioxidant activity of samples, namely reducing sugars (e.g., fructose and glucose), tocopherols and phenolic compounds. Tocopherols have been recognized as the most important natural antioxidants in foods, being their activity mainly conferred by their prominent action as free radical scavengers and hydrogen donators (Jaguar et al., 2016); $\alpha$-tocopherol, by far the majority tocopherol present in the analysed samples, is the isoform with the highest biological potential. On the other hand, 5-O-caffeoylquinic acid is the predominant form of chlorogenic acid in plants, being its antioxidant potential mainly attributed to the presence of the double bond in the aliphatic chain conjugated with the catechol structure of its phenyl ring. Interestingly, higher contents of chlorogenic acids have been found in plants having more pronounced antioxidant, hepatoprotective and antiviral effects, either reported in vitro, in vivo or in epidemiological studies (Marques et al., 2009). Their prominent antioxidant activity seems to be related with the ability to decrease reactive oxygen species, through deactivation of a wide range of pro-oxidant enzymes, including lipoxygenase (LOX)mediated arachidonic acid metabolism inhibition, still remaining many other mechanisms unexplored (Gawlik-Dziki et al., 2014). Those perceptions seem to be confirmed in the present study, where the antioxidant activity appears to be closely related with phenolic compounds and tocopherols composition, with samples showing higher content of these components also having higher antioxidant activity. 
CONCLUDING
REMARKS 


\section{CONCLUSIONS}

Stevia rebaudiana is widely known for its natural sweeteners content, although this plant could also be considered as a good source of antioxidants, such as phenolic compounds. However, appropriate methodologies have to be applied to preserve its chemical constituents. In the present work, it has been proved that oven-dried processed samples show higher antioxidant activity and phenolic compounds contents than frozen fresh samples, whereas these latter possess higher levels of tocopherols and free sugars. Thus, while it is very important to establish suitable conditions to cultivate S. rebaudiana in order to standardize its chemical composition, not least important is the preservation process selected for this plant. Another relevant conclusion was that the preservation process exerts higher impact on the chemical content than $\mathrm{N}$ fertilization during plant cultivation. Moreover, stevia samples with the highest abundance in phenolic compounds and free sugars (i.e. dried processed samples, and N1 and control N0 samples) and with the lowest levels of tocopherols, were also those that revealed the highest reducing power, whereas stevia samples with the highest tocopherols content presented the highest radical scavenging activity. Therefore, it seems that the antioxidant activity of stevia leaves is closely determined by its composition and the mechanism of action involved. Nevertheless, good correlation factors were, in general, obtained between the antioxidant activity and some phenolic compounds, especially quercetin-3-O-rutinoside, which presented the most significant correlation with both antioxidant activities tested, as also the major individual phenolic compound, 5- $O$-caffeoylquinic acid, that also had a high correlation factor.

In vitro cultivation of stevia plants with and without kinetin in order to evaluate the protective and/or strengthening effect of this phytoregulator in the antioxidant components and activity, showed that it did not provide significant incremental effect neither on stevia antioxidant potential nor on the considered compounds (except for some secondary chlorogenic acids (i.e., 3-O-caffeoylquinic and 4-O-caffeoylquinic acids) and sugar contents), although it results in a higher plant multiplication rate. Further studies should be performed to determine if kinetin at different concentrations could increase stevia antioxidants, as also to test other plant growth phytoregulators, as well as cultivation media and stress conditions. This assessment will be of utmost importance, as micropropagation technique is an efficient process to obtain plant material for industrial exploitation. The in vitro culture allows a continuously biomass production regardless of the edaphoclimatic conditions, which makes it an added value for studies without climatic or space constraints. 
The results herein obtained regarding cultivation practices and how they can affect the quality and chemical composition of stevia leaves, may provide considerable insights for their upcoming use for health-promoting purposes. 
RESUMEN 
RESUMEN DE LA TESIS DOCTORAL:

Cultivo de Stevia rebaudiana Bertoni en campo y por micropropagación in vitro: estudio prospectivo de su potencial antioxidante en función del tipo de cultivo y de las condiciones de conservación

\section{ÍNDICE}

1.1. Stevia rebaudiana Bertoni 63

1.2. Procesos de conservación 64

1.3. Fertilización para mejorar la producción de compuestos bioactivos Erro!

Marcador não definido.5

1.4. Fitohormonas para mejorar la producción in vitro de compuestos bioactivos 66

OBJETIVOS 67

PRINCIPALES RESULTADOS 68 


\section{INTRODUCCIÓN}

\subsection{Stevia rebaudiana Bertoni}

Stevia rebaudiana Bertoni (estevia) es un arbusto perenne, miembro de la familia Asteraceae, que alcanza hasta $90 \mathrm{~cm}$ de altura, con hojas pequeñas de 3 a $5 \mathrm{~cm}$ de longitud y 1 a 1,5 cm de ancho. Las flores son blancas y los pétalos se agrupan en racimos terminales o axilares. Crecen en altitudes de 500-3000 m en zonas de montaña semiseca, pero también pueden crecer en pastizales, matorrales y áreas subalpinas (Magalhães et al., 2000; Serfaty et al., 2013). Es una planta originaria del noreste de Paraguay y áreas vecinas de Brasil y Argentina, cuyas hojas secas han sido utilizadas durante siglos por los indígenas guaraníes de América del Sur como un edulcorante tradicional, al que llaman ka'a he'ê ("hierba dulce"). Actualmente, la estevia es reconocida por sus propiedades edulcorantes y, en este sentido, constituye una especie de interés económico emergente en todo el mundo (Khalil et al., 2016). China es el mayor productor mundial, aunque también se cultiva en otros lugares, como Japón, Taiwán, Tailandia, Corea, Brasil, Malasia, Paraguay y algunos países de la Unión Europea. Japón y Corea son sus mercados más importantes (Yadav et al., 2010). El esteviósido $\left(\mathrm{C}_{38} \mathrm{H}_{60} \mathrm{O}_{18}\right)$, un compuesto diterpenoide, es el edulcorante principal producido por la estevia. Los glicósidos de esteviol (SGs) pueden alcanzar hasta el 30\% del peso seco de la hoja de estevia (Geuns et al., 2003) y tienen un poder edulcorante unas 300 veces mayor que el de la sacarosa (Gardana et al., 2010). En los mercados internacionales, los edulcorantes derivados de la estevia se comercializan comúnmente en forma de extractos líquidos o como cristales de esteviósido (Bender, 2018). Japón fue el primer país de Asia en comercializar el esteviósido como edulcorante para las industrias de alimentos y medicamentos (Pal et al., 2015; Bender, 2018).

La demanda de edulcorantes naturales ha ido creciendo en importancia debido a la controversia asociada al uso de algunos edulcorantes sintéticos como ciclamato, aspartamo o acesulfamo K. Los SGs se han utilizado ampliamente como edulcorantes naturales no calóricos en productos como refrescos, salsa de soja, sopas de pasta o yogur en Japón, Brasil y otros países. La Autoridad Europea de Seguridad Alimentaria reconoció la seguridad del extracto de hoja de estevia para uso alimentario en 2011 estando actualmente reconocido como aditivo alimentario en la Unión Europea con el código E-960 (Yu et al., 2017). Las hojas de estevia también se consumen cada vez más como infusiones por sus propiedades 
antioxidantes, que se han relacionado con sus contenidos de compuestos fenólicos (Periche et al., 2015).

Además de esteviósido, los extractos de estevia contienen también otros metabolitos con potencial bioactivo, como alcaloides, complejos clorofila-proteína solubles en agua, xantofilas, compuestos fenólicos, oligosacáridos neutros solubles en agua, azúcares libres, aminoácidos, lípidos, aceites esenciales y oligoelementos (Komissarenko et al., 1994). También se ha descrito que poseen actividades antimicrobianas y antioxidantes (Xi et al., 1998; Tadhani et al., 2007). Entre los antioxidantes de la hoja de estevia se encuentran compuestos como los tocoferoles, ácido ascórbico (Kim et al., 2011) o compuestos fenólicos (Shukla et al., 2009).

Los compuestos fenólicos son metabolitos secundarios de plantas superiores sintetizados para una variedad de funciones, entre las que se incluyen los mecanismos de resistencia natural contra el estrés biótico y abiótico, defensa frente herbívoros o procesos de señalización celular. Como componentes de los alimentos, estos compuestos se han relacionado con la prevención de enfermedades de origen oxidativo, como la enfermedad coronaria (Robbins et al., 2005). Otras propiedades descritas para los compuestos fenólicos incluyen actividades anticariogénicas, antineoplásicas, antihipertensivas, antiinflamatorias y antihiperglucémicas (Yang et al., 2015).

\subsection{Procesos de conservación}

Las plantas con valor comercial a menudo se almacenan durante un tiempo variable antes de su uso y una conservación eficiente es muy importante para evitar la pérdida de moléculas bioactivas. El secado es la forma más antigua de preservar el material vegetal. En este proceso, se pierde hasta el $85 \%$ de peso y durante el mismo pueden producirse pérdidas de componentes de bajo punto de ebullición y cambios que afectan la composición nutricional, física y química de las hojas, así como atributos de calidad como textura, color y sabor (Babu et al. 2018; Ahmad-Qasem et al., 2013). El mayor inconveniente, sin duda, radica en las pérdidas de componentes nutritivos durante el procesado térmico a alta temperatura, como vitaminas termolábiles (Korus et al., 2011). Por otro lado, debido al bajo contenido de agua, las plantas secas presentan mayor densidad de nutrientes y de componentes bioactivos que las frescas (Babu et al., 2018). 
La congelación de alimentos es otro método eficiente de conservación y almacenamiento utilizado para preservar las materias primas vegetales, tanto en la industria alimentaria como en el hogar, aunque su coste es mayor que el secado con aire caliente (Periche et al., 2015; Korus et al., 2011). Las bajas temperaturas utilizadas en esta técnica contribuyen a mantener la calidad inicial y el valor nutritivo con pocos cambios. En general, se considera que el secado por liofilización es el proceso que da lugar a productos secos de mayor calidad, aunque se trata de un proceso costoso.

\subsection{Fertilización para mejorar la producción de compuestos bioactivos}

Muchas propiedades funcionales de los alimentos se basan en las acciones de componentes bioactivos específicos. La concentración de metabolitos secundarios bioactivos de las plantas (fitoquímicos) está influida por las condiciones de cultivo, como la intensidad luminosa, niveles de dióxido de carbono, temperatura, fertilización o factores bióticos y abióticos (Ibrahim et al., 2011). La diversidad química y biológica de las plantas de estevia está asimismo determinada por factores como el genotipo, la etapa fenológica y las condiciones de crecimiento (Brandle \& Rosa, 1992; Brandle et al., 1998; Yadav et al., 2010). La fertilización con nitrógeno $(\mathrm{N})$, fósforo $(\mathrm{P})$ y potasio $(\mathrm{K})$, así como el estado de la planta, juegan un papel importante en la definición de la concentración final de metabolitos secundarios (Aires et al., 2006). El N es uno de los elementos esenciales más importantes para las plantas, siendo utilizado para sintetizar muchos compuestos orgánicos, como aminoácidos, proteínas, enzimas y ácidos nucleicos (Koeduka et al., 2006). Además, tiene otras funciones en la vida de las plantas, como las relacionadas con el rendimiento en obtención de biomasa (Rodrigues et al., 2016). Se ha indicado que la disponibilidad de $\mathrm{N}$ no sólo influye en la producción de metabolitos secundarios de manera predecible, sino también en los procesos de diferenciación y crecimiento de las plantas (Aires et al., 2006; Ibrahim et al., 2011). De esta manera, es de esperar que el empleo de distintas tasas de fertilización con $\mathrm{N}$ tenga influencia en la biosíntesis de constituyentes activos (Karimi et al., 2013). En estudios sobre plantas como manzana o pomelo, se encontró que el empleo de concentraciones crecientes de $\mathrm{N}$ ejercía un efecto negativo en la biosíntesis de flavonoides o ácido clorogénico (Patil y Alva, 1999; Awad \& de Jager, 2002), mientras que su déficit aumentaba la concentración de flavonoides en tomate (Bongue y Phillips, 1995). Existe, sin embargo, una falta de información sobre los efectos reales de la fertilización en las propiedades químicas y bioactivas de $S$. rebaudiana. Tavarini et al. (2015) observaron que 
tanto la fertilización con $\mathrm{N}$ como el momento de cosecha tenían una influencia pronunciada sobre la composición fitoquímica y la actividad antioxidante de la estevia. Estos resultados sugieren que un adecuado manejo del nivel de fertilización podría ser utilizado para modificar la expresión de metabolitos secundarios.

\subsection{Fitohormonas para mejorar la producción in vitro de compuestos bioactivos}

Las técnicas de cultivo de tejidos vegetales se utilizan para cultivar células, tejidos y órganos de plantas en condiciones axénicas (in vitro), así como para regenerar y propagar plantas completas. El cultivo in vitro en un ambiente controlado, con un conocimiento adecuado de las condiciones requeridas y de la naturaleza del material vegetal, garantiza una propagación clonal efectiva de genotipos seleccionados por sus mejores características de plantas económicamente importantes (Iliev et al., 2010).

Estas técnicas son empleadas en muchos laboratorios comerciales e institutos de investigación, ya que ofrecen ciertas ventajas sobre los métodos clásicos de propagación, para multiplicación rápida de plantas, conservación de germoplasma, eliminación de patógenos, manipulación genética y producción de metabolitos secundarios utilizados como productos farmacéuticos, aromas, fragancias, colorantes, aditivos alimentarios o agroquímicos (Wang et al., 2017; Kumar \& Reddy, 2011). El empleo de reguladores del crecimiento, o fitohormonas, ha revolucionado el desarrollo del cultivo de plantas in vitro, al permitir el control de procesos fisiológicos de células más especializadas y la inducción de la producción de metabolitos secundarios (Dias et al., 2016).

Existen tres tipos de técnicas de micropropagación: 1) la propagación de brotes empleando citoquininas, como benciladenina o cinetina; 2) la obtención diferenciada de brotes múltiples a partir de tejido indiferenciado (callo) utilizando auxinas, como el ácido indol acético, y 3) la diferenciación embrionaria a partir de callos. Hoy en día, el método de propagación de brotes es el más empleado, ya que los otros dos están sujetos a variaciones genéticas al partir de material indiferenciado (Ota y Yokoyama 2010). Las citoquininas son un grupo de fitohormonas que estimulan la captación de agua, aumentan la división celular, promueven el desarrollo de órganos y conducen a la regeneración y proliferación de brotes. La cinetina (6-furfurilaminopurina) es un ejemplo de citoquinina sintética que tiene capacidad para mitigar los efectos adversos del estrés salino durante el crecimiento de las plantas (Eser et al., 2016). 


\section{OBJETIVOS}

La realización de estudios con condiciones de cultivo bien establecidas es de extrema importancia para estandarizar la producción de plantas y, por lo tanto, su composición química. Sin embargo, las condiciones de conservación también pueden influir sobre los compuestos bioactivos presentes en la mismas.

Considerando que tanto las condiciones de cultivo como de conservación ejercen un papel determinante sobre la actividad biológica de Stevia rebaudiana, en el presente trabajo se han planteado los siguientes objetivos:

1. Evaluar los efectos de procesos de conservación sobre el potencial antioxidante de $S$. rebaudiana, comparando la actividad captadora de radicales libres, el poder reductor y la composición de sustancias antioxidantes de muestras congeladas en fresco y plantas desecadas. Las muestras a estudiar se obtendrán de campos experimentales en condiciones de cultivo definidas, para estandarizar la producción y, por tanto, su composición química.

2. Evaluar el efecto de diferentes tasas de aplicación de $\mathrm{N}$ sobre la composición química en hojas de estevia posteriormente congeladas o desecadas, y definir las mejores condiciones de cultivo para maximizar los niveles de estos compuestos.

3. Analizar en cuanto a su potencial antioxidante hojas de estevia obtenidas por cultivo in vitro; más específicamente, muestras obtenidas en presencia de cinetina se compararán con muestras cultivadas sin esta fitohormona, en cuanto a composición de tocoferoles, azúcares libres y compuestos fenólicos y propiedades antioxidantes. 


\section{PRINCIPALES RESULTADOS}

Muestras de Stevia rebaudiana Bertoni cultivadas en el noreste de Portugal fueron sometidas a dos condiciones de conservación diferentes: secado en invernadero a $30{ }^{\circ} \mathrm{C}$ y congelación en fresco a $-20{ }^{\circ} \mathrm{C}$, y posteriormente almacenadas durante seis días. Por otra parte, para definir las mejores condiciones de cultivo y maximizar los niveles de compuestos bioactivos, se evaluó también el efecto de diferentes concentraciones de nitrógeno (N) sobre la composición química y las propiedades antioxidantes de las hojas frescas y secas congeladas de estevia. En todos los casos, las muestras fueron caracterizadas en cuanto a cuantificación e identificación de azúcares libres, tocoferoles y compuestos fenólicos, y determinación del potencial antioxidante mediante ensayos de captación del radical DPPH y poder reductor (RP) de sus extractos metanol:agua.

Los azúcares más abundantes en las muestras estudiadas fueron xilosa, arabinosa + fructosa y sacarosa, mientras que los principales compuestos fenólicos fueron los derivados del ácido cafeico, ácido 5-O-cafeoilquínico (ácido clorogénico) y ácido 3,5-O-dicafeoilquínico.

Las muestras secadas en invernadero dieron lugar a valores más elevados de actividad antioxidante y de compuestos fenólicos totales que las mantenidas a $-20^{\circ} \mathrm{C}$. Sin embargo, las muestras frescas congeladas presentaron contenidos más altos de tocoferoles y de azúcares totales. Se pudo comprobar que el proceso de conservación afectaba más significativamente los valores de tocoferoles y de contenido de azúcares que la fertilización con N. En general, la fertilización con N conducía a una mejora en la composición química y el potencial bioactivo de las hojas de estevia. Los mayores niveles de compuestos fenólicos se encontraron en las muestras secas y en aquellas fertilizadas con $25 \mathrm{~kg}$ de N/ha. Las hojas de plantas fertilizadas con 25 y $50 \mathrm{~kg}$ N/ha también fueron las que evidenciaron mayor actividad antioxidante, que parecía estar especialmente determinada por la composición fenólica.

Los reguladores del crecimiento de las plantas, que controlan los procesos fisiológicos en células especializadas, se utilizan en el desarrollo de cultivos de plantas in vitro. Por ello, se estudió también la composición en azúcares libres, tocoferoles y compuestos fenólicos y el potencial antioxidante en hojas de estevia obtenidas por cultivo in vitro con y sin cinetina (fitorregulador). Las muestras cultivadas sin cinetina evidenciaron una mayor concentración de tocoferoles totales y de compuestos fenólicos que las obtenidas en presencia de cinetina. Por lo contrario, se observó una tendencia opuesta para los azúcares libres totales. Los 
extractos de metanol:agua obtenidos de muestras cultivadas sin cinetina también evidenciaron mayor actividad captadora de radicales y poder reductor que los de las muestras cultivadas en presencia de cinetina, lo que parece confirmar la relación de este fitorregulador con la producción de compuestos fenólicos. En general, el cultivo in vitro es una forma eficaz de obtener biomasa vegetal que pueda ser utilizada como fuente de compuestos antioxidantes de manera continua y sin estar sometida a condiciones edafoclimáticas. Sin embargo, a las dosis ensayadas el empleo de cinetina, aunque mejoró la tasa de multiplicación, no condujo a una mayor acumulación de moléculas bioactivas, por lo que se deberían ensayar otros niveles de aplicación de este regulador, así como otras hormonas para establecer su influencia sobre la producción de este tipo de compuestos.

El estudio realizado proporciona evidencias para elegir la metodología más apropiada para favorecer la acumulación y preservar los niveles de metabolitos primarios y secundarios de Stevia rebaudiana relacionados con su actividad antioxidante. Los resultados obtenidos con relación a las prácticas de cultivo y su influencia sobre la calidad y la composición fitoquímica de hojas de estevia aportan información relevante de cara a su producción y posible empleo con fines de promoción de la salud, como nutracéuticos o ingredientes de alimentos funcionales. 


\section{CONCLUSIONES}

En el presente trabajo, se ha demostrado que muestras procesadas por desecación presentan mayor actividad antioxidante y contenido de compuestos fenólicos que muestras congeladas en fresco, mientras que estas últimas poseen mayores niveles de tocoferoles y de azúcares libres. De este modo, se ha comprobado que tan importante como establecer condiciones de cultivo de $S$. rebaudiana adecuadas para estandarizar la composición química, lo es el proceso de conservación elegido para el almacenamiento de esta planta.

Otra conclusión relevante es que el proceso de conservación ejerce mayor impacto sobre la composición química que la fertilización con $\mathrm{N}$ durante el cultivo de la planta. Las muestras de estevia con mayor abundancia de compuestos fenólicos y de azúcares libres (es decir, las desecadas y aquellas no fertilizadas o cultivadas con bajo nivel de fertilización) son también las que poseen la mayor capacidad reductora. Por su parte, las muestras de estevia con mayores contenidos de tocoferoles poseen mayor actividad captadora de radicales libres. Parece, por tanto, que la actividad antioxidante de las hojas de estevia está estrechamente relacionada con su composición fitoquímica y los mecanismos de acción antioxidante considerados. En todo caso, existe, en general, una buena correlación entre la actividad antioxidante y el contenido de algunos compuestos fenólicos presentes en las muestras, especialmente quercetina-3-O-rutinósido y ácido 5-O-cafeoliquínico (compuesto fenólico mayoritario en las hojas de estevia).

El cultivo in vitro de plantas de estevia con $\mathrm{y}$ sin cinetina no produce un aumento significativo ni en el potencial antioxidante ni en los contenidos de compuestos fenólicos (excepto en el caso de algunos ácidos clorogénicos secundarios) y de azúcares libres, aunque da lugar a una mayor tasa de multiplicación, lo que es interesante con vistas a la producción industrial. Son necesarios más estudios para establecer si el empleo de otras concentraciones de cinetina podría mejorar la acumulación de sustancias antioxidantes en la hoja, así como ensayar otros fitorreguladores y condiciones de cultivo y de estrés. Esta evaluación sería de gran importancia, ya que las técnicas de micropropagación constituyen una herramienta eficaz para obtener biomasa vegetal para explotación industrial. El cultivo in vitro permite la producción continua sin depender de condiciones edafoclimáticas, lo que lo hace de gran valor para estudios sin las limitaciones impuestas por el clima o el terreno. 
REFERENCES 


\section{REFERENCES}

\section{A}

Abou-Arab, E.A., Abu-Salem, F.M., 2010. Evaluation of bioactive compounds of Stevia rebaudiana leaves and callus. Afr. J. Food Sci., 4, 627-634.

Ahmed, A.M.A.; Khalid, K.A., 2017. Influence of kinetin on growth, chemical constituents and nutrient content of black cumin (Nigella sativa L.). Bangladesh J. Bot., 46, 783-787.

Ahmad-Qasem, M.H., Barrajón-Catalán, E., Micol, V., Mulet, A., García-Pérez, J.V., 2013. Influence of freezing and dehydration of olive leaves (var. Serrana) on extract composition and antioxidant potential. Food Resea. Int., 1, 50,189-196.

Aires, A., Rosa, E., \& Carvalho, R., 2006. Effect of nitrogen and sulfur fertilization on glucosinolates in the leaves and roots of broccoli sprouts (Brassica oleracea var. italica). J. of the Sci. of Food and Agric., 86, 1512-1516.

Álvarez-Robles, M. J., López-Orenes, A., Ferrer, M.A., \& Calderón, A.A., 2016. Methanol elicits the accumulation of bioactive steviol glycosides and phenolics in Stevia rebaudiana shoot cultures. Indus. Crops and Prod., 87, 273-279.

Awad, M.A., \& de Jager, A., 2002. Relationship between fruit nutrients and concentrations of flavonoids and chlorogenic acid in 'Elstar' apple skin. Sci. Hort., 92, 265-276.

\section{B}

Babu, A.K., Kumaresan, G., Antony Aroul Raj, V., Velraj, R., 2018. Review of leaf drying: Mechanism and influencing parameters, drying methods, nutrient preservation, and mathematical models. Renew. and Sustain. Ener. Rev., 90, 536-556.

Barba, F.J., Grimi, N., Vorobiev E., 2015. Evaluating the potential of cell disruption technologies for green selective extraction of antioxidant compounds from Stevia rebaudiana Bertoni leaves. J. Food Eng., 149, 222-228.

Barros, L., Pereira, E., Calhelha, R. C., Dueñas, M., Carvalho, A. M., Santos-Buelga, C., Ferreira, I.C.F.R., 2013. Bioactivity and chemical characterization in hydrophilic and lipophilic compounds of Chenopodium ambrosioides L. J. Funct. Food., 5, 1732-1740.

Bender C., 2018. Stevia Rebaudiana's Antioxidant Properties. J.-M. Mérillon, K.G. Ramawat (eds.), Sweeteners, Reference Series in Phytochem., 349-375. 
Bessada, S. M., Barreira, J.C.M., Barros, L., Ferreira, I.C.F.R., \& Oliveira, M.B.P.P., 2016. Phenolic profile and antioxidant activity of Coleostephus myconis (L.) Rchb. f.: An underexploited and highly disseminated species. Ind. Crops and Prod.s, 89, 45-51.

Brandle, J., \& Rosa, N., 1992. Heritability for yield, leaf: stem ratio and stevioside content estimated from a landrace cultivar of Stevia rebaudiana. Can. Jour. of Plant Sci., 72, $1263-1266$.

Brandle, J.E., Starratt, A.N., \& Gijzen, M., 1998. Stevia rebaudiana: Its agricultural, biological, and chemical properties. Canadian Journal of Plant Science, 78, 527-536.

Brandle, J.E., Telmer, P.G., 2007. Steviol glycoside biosynthesis. Phytochemistry, 68, 1855-1863.

Bongue-B. M. \&; Phillips, D.A. 1995. Nitrogen stress regulates gene expression of enzymes in the flavonoid biosynthetic pathway of tomato. Plant Physiol. Biochem., 33, 539-546.

\section{C}

Cacciola, F., Delmonte, P., Jaworska, K., Dugo, P., Mondello, L., Rader, J.I., 2011. Employing ultra high pressure liquid chromatography as the second dimension in a comprehensive two-dimensional system for analysis of Stevia rebaudiana extracts. J. Chromatogr., A 1218, 2012-2018.

Carocho, M., Morales, P., Ferreira, I.C.F.R., 2015. Natural food additives: Quo vadis? Trends Food Sci. Technol., 45, 284-295.

Ceunen, S., Geuns, J.M.C., 2013. Influence of photoperiodism on the spatio-temporal accumulation of steviol glycosides in Stevia rebaudiana (Bertoni). Plant Sci., 198, 72-82.

Clifford, M.N., Johnston, K.L., Knight, S., Kuhnert, N.A., 2003. A hierarchical scheme for LC-MS ${ }^{\mathrm{n}}$ identification of chlorogenic acids. J Agric. Food Chem., 51, 2900-2911.

Clifford, M.N., Knight, S., Kuhnert, N.A., 2005. Discriminating between the six isomers of dicaffeoylquinic acid by LC-MS ${ }^{\mathrm{n}}$. J. Agric. Food Chem., 53, 3821-3832.

\section{D}

Dacome, A.S., Silva, C.C., Costa, C.E.M., Fontana, J.D., Adelmann, J., Costa, S.C., 2005. Sweet diterpenic glycosides balance of a new cultivar of Stevia rebaudiana (Bert) Bertoni: isolation and quantitative distribution by chromatographic, spectroscopic and electrophoretic methods. Process Biochem., 44, 3587-3594. 
Dias, M.I.; Sousa, M.J.; Alves, R.C.; Ferreira, I.C.F.R., 2016. Exploring plant tissue culture to improve the production of phenolic compounds: A review. Ind. Crops Prod., 82, 9-22.

\section{$\mathbf{E}$}

Eser, A.; Aydemir, T., 2016. The effect of kinetin on wheat seedlings exposed to boron. Plant Physiol. Biochem., 108, 158-164.

\section{$\mathbf{F}$}

Fernandes, Â., Barreira, J.C.M., António, A.L., Santos, P.M.P., Martins, A., Oliveira, M.B.P.P., Ferreira, I.C.F.R., 2013. Study of chemical changes and antioxidant activity variation induced by gamma-irradiation on wild mushrooms: Comparative study through principal component analysis. Food Res. Int., 54, 18-25.

Ferreira, I.C.F.R.; Martins, N.; Barros, L., 2017. Phenolic compounds and its bioavailability: in vitro bioactive compounds or health promoters? Adv. Food Nutr. Res., $82,1-44$

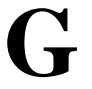

Gardana, C., Scaglianti, M., Simonetti, P., 2010. Evaluation of steviol and its glycosides in Stevia rebaudiana leaves and commercial sweetener by ultra-high-performance liquid chromatography-mass spectrometry. J. Chromatogr., A 1217, 1463-1470.

Ghanta, S., Banerjee, A., Poddar, A., Chattopadhyay, S., 2007. Oxidative DNA damage preventive activity and antioxidant potential of Stevia rebaudiana (Bertoni) Bertoni, a natural sweetener. J. Agric. Food Chem., 55, 10962-10967.

Gaweł-Bęben, K., Bujak, T., Nizioł-Łukaszewska, Z., Antosiewicz, B., Jakubczyk, A., Karaś M., Rybczyńska, K., 2015. Stevia rebaudiana Bert. leaf extracts as a multifunctional source of natural antioxidants. Molecules, 20, 5468-5486.

Gawlik-Dziki, U.; Świeca, M.; Dziki, D.; Kowalska, I.; Pecio, Ł.; Durak, A.; Seczyk, Ł., 2014. Lipoxygenase inhibitors and antioxidants from green coffee-mechanism of action in the light of potential bioaccessibility. Food Res. Int., 61, 48-55. 
Geuns, J.M.C., Augustijns, P., Mols, R., 2003. Metabolism of stevioside in pigs and intestinal absorption characteristics of stevioside, rebaudioside $\mathrm{A}$ and steviol. Food Chem. Toxicol., 41, 1599-1607.

Goyal, S.K., Samsher, \& Goyal, R.K., 2010. Stevia (Stevia rebaudiana) a bio-sweetener: a review. Int. J. of Food Sci. and Nutrit., 61(1), 1-10.

Gupta, E., Purwar, S., Sundaram, S., \& Rai, G.K., 2013. Nutritional and therapeutic values of Stevia rebaudiana: A review. J. of Med. Plant Resea., 7(46), 3343-3353.

I

Ibrahim, M.H., Jaafar, H.Z.E., Rahmat, A., \& Rahman, Z.A., 2011. Effects of nitrogen fertilization on synthesis of primary and secondary metabolites in three varieties of kacip fatimah (Labisia pumila blume). Int. J. of Molec. Sci., 12(8), 5238-5254.

Ibrahim, M.H., Jaafar, H.Z.E., Rahmat, A., \& Rahman, Z.A., 2012. Involvement of Nitrogen on Flavonoids, Glutathione, Anthocyanin, Ascorbic Acid and Antioxidant Activities of Malaysian Medicinal Plant Labisia pumila Blume (Kacip Fatimah) Int. J. Mol. Sci., 13, 393-408.

Iliev, I, Gajdosov, A., Libiakova, G., and Jain, S.M., 2010. Plant Micropropagation. Plant Cell Culture, 2-23.

\section{$\mathbf{J}$}

Jabeur, I.; Tobaldini, F.; Martins, N.; Barros, L.; Martins, I.; Calhelha, R.C.; Henriques, M.; Silva, S.; Achour, L.; Santos-Buelga, C.; Ferreira, I.C.F.R., 2016. Bioactive properties and functional constituents of Hypericum androsaemum L.: A focus on the phenolic profile. Food Res. Int., 89, 422-431.

Jahan, I.A., Mostafa, M., Hossain, H., Nimmi, I., Sattar, A., Alim, A., Moeiz, S.M.I., 2010. Antioxidant activity of Stevia rebaudiana Bert. leaves from Bangladesh. Bangladesh Pharm. J., 13, 67-75. 


\section{$\mathbf{K}$}

Karakose, H., Jaiswal, R., Kuhnert, N., 2011. Characterization and quantification of hydroxycinnamate derivatives in Stevia rebaudiana leaves by $\mathrm{LC}^{-\mathrm{MS}^{\mathrm{n}}{ }^{\dagger}}$. J. Agric. Food Chem., 59, 10143-10150.

Karakose, H., Muller, A., Kuhnert, N., 2015. Profiling and quantification of phenolics in Stevia rebaudiana leaves. J. Agric. Food Chem., 63, 9188-9198.

Karimi, E., Jaafar, H.Z.E., \& Ahmad, S., 2013. Antifungal, anti-inflammatory and cytotoxicity activities of three varieties of labisia pumila benth: from microwave obtained extracts. BMC Complem. and Alternat. Med., 13(20), 1-10.

Karimi, M., Ahmadi, A., Hashemi, J., Abbasi, A., Tavarini, S., Guglielminetti, L., Angelini L. G., 2015. The effect of soil moisture depletion on Stevia (Stevia rebaudiana Bertoni) grown in greenhouse conditions: Growth, steviol glycosides content, soluble sugars and total antioxidant capacity. Sci. Hort., 183, 93-99.

Kim, I., Yang, M., Lee, O., Kang, S., 2011. The antioxidant activity and the bioactive compound content of Stevia rebaudiana water extracts. Food Sci. Technol., 44, 13281332 .

Khalil, S.A.; Kamal, N.; Sajid, M.; Ahmad, N.; Zamir, R.; Ahmad, N.; Ali, S., 2016. Synergism of polyamines and plant growth regulators enhanced morphogenesis, stevioside content, and production of commercially important natural antioxidants in Stevia rebaudiana Bert. Vitr. Cell. Dev. Biol.- Plant, 52, 174-184.

Koeduka, T., Fridman, E., Gang, D.R., Vassão, D.G., Jackson, B.L., Kish, C.M., ... Pichersky, E. 2006. Eugenol and isoeugenol, characteristic aromatic constituents of spices, are biosynthesized via reduction of a coniferyl alcohol ester. Proceedi. of the Natio. Acad. of Sci. of the U. S. A., 103(26), 10128-10133.

Komissarenko, N.F., Derkach, A.I., Kovalyov, I.P., Bublik, N.P., 1994. Diterpene glycosides and phenylpropanoids of Stevia rebaudiana Bertoni. Rastitel'Nye Resursy, 1, $53-64$.

Korus, A., Lisiewska, Z., 2011. Effect of preliminary processing and method of preservation on the content of selected antioxidative compounds in kale (Brassica oleracea L. var. acephala) leaves. Food Chem., 129, 149-154. 
Koyama, E., Kitazawa K., Ohori, Y., Izawa, O., Kakegawa, K., Fujino, A., Ui,M., 2003. In vitro metabolism of the glycosidic sweeteners, Stevia mixture and enzymatically modified Stevia in human intestinal microflora. Food Chem. Toxicol., 41, 359-374.

Kumar, N. \& Reddy, M.P., 2011. In vitro Plant Propagation: A Review. J. of Forest Sci., 27(2), 61-72.

$\mathbf{L}$

Liao, S.-G., Zhang, L.-J., Li, C.-B., Lan, Y.-Y., Wang, A.-M., Huang, Y., Zhen, L., Fu, X.Z., Zhou, W., Qi, X.-L., Guan Z.-Z., Wang Y.-L., 2010. Rapid screening and identification of caffeic acid and its esters in Erigeron breviscapus by ultra-performance liquid chromatography/tandem mass spectrometry. Rapid Commun. Mass Spectrom., 24, 2533-2541.

Lin, S.D., Sung, J.M., \& Chen, C.L., (2011). Effect of drying and storage conditions on caffeic acid derivatives and total phenolics of Echinacea Purpurea grown in Taiwan. Food Chem., 125, 226-231.

M

Magalhães, P.M., de Martínez, A.J.V., Yesid, B.H., Cáceres, A., 2000. Agrotecnología para el cultivo de estevia o hierba dulce. In: CAB, CYTED (Eds.), Fundamentos de agrotecnología de cultivo de plantas medicinales ibero americanas. Colombia, 441450 .

Madan, S., Ahmad, S., Singh, G.N., Kohli, K., Kumar, Y., Singh, R., Garg, M., 2010. Stevia rebaudiana (Bert.) Bertoni - A Review. Indian J. Natural Prod. Res., 1, 267-286.

Marques, V.; Farah, A., 2009. Chlorogenic acids and related compounds in medicinal plants and infusions. Food Chem., 113, 1370-1376.

Muanda, F. N., Soulimani, R., Diop, B., Dicko, A., 2011. Study on chemical composition and biological activities of essential oil and extracts from Stevia rebaudiana Bertoni leaves. Food Sci. Technol., 44, 1865-1872. 
Mullen W., Stewart, A.J., Lean, M.E.J., Gardner, P., Duthie, G.G., and Crozier, A., 2002. Effect of Freezing and Storage on the Phenolics, Ellagitannins, Flavonoids, and Antioxidant Capacity of Red Raspberries. J. Agric. Food Chem. 2002, 50, 5197-5201.

Murashige, T. and Skoog, F., 1962. A revised medium for rapid growth and bio assays with tobacco tissue cultures. Physiol. Plant., 13, 473-497.

$\mathbf{N}$

Navale, S.R., Supriya U., Harpale, V.M. Mohite, K.C., 2014 Effect of Solar Drying on the Nutritive Value of Fenugreek Leaves. Int. J. of Eng. and Adv. Technol., 4, 133-136.

\section{$\mathbf{O}$}

Ota. M., \& Yokoyama, M., 2010. Chemistry of Cosmetics, Shiseido Co., Ltd., Yokohama, Japan, 317-348.

\section{$\mathbf{P}$}

Pal, P.K., Kumar, R., Guleria, V., Mahajan, M., Prasad, R., Pathania, V., Gill, B.S., Singh, D., Chand, G., Singh, B., Singh, R.D., Ahuja, P.S., 2015. Crop-ecology and nutritional variability influence growth and secondary metabolites of Stevia rebaudiana Bertoni. BMC Plant Biology, 15, 67.

Patil, B.S.; Alva, A.K., 1999. Enhancing citrus nutraceuticals through variable nutrient rates. Hort. Sci., 34, 520-520.

Pereira, C., Barros, L., Ferreira, I.C.F.R., 2015. A comparison of the nutritional contribution of thirty-nine aromatic plants used as condiments and/or herbal infusions. Plant Foods Hum. Nutr., 70, 176-183.

Periche, A., Castelló, M.L., Escriche, I., 2015. Influence of drying method on steviol glycosides and antioxidants in Stevia rebaudiana leaves. Food Chem., 173, 1-6.

Pinela, J., Barros, L., Carvalho, A.M., Ferreira, I.C.F.R., 2011. Influence of the drying method in the antioxidant potential of four shrubby flowering plants from the tribe Genisteae (Fabaceae). Food Chem. Toxicol., 49, 2983-2989. 


\section{$\mathbf{R}$}

Radić, S.; Vujčić, V.; Glogoški, M.; Radić-Stojković, M., 2016. Influence of pH and plant growth regulators on secondary metabolite production and antioxidant activity of Stevia rebaudiana (Bert). Period. Biol., 118, 9-19.

Rajasekaran, T., Ramakrishna, A., Sankar, K.U., Giridhar, P., \& Ravishankar, G.A., 2008. Analysis of predominant steviosides in Stevia rebaudiana Bertoni by liquid chromatography/electrospray ionization-mass spectrometry. Food Biotechnol., 22(2), $179-188$.

Reis R.V., Chierrito T.P.C., Silva T.F.O., Albiero A.L.M., Souza L.A., Gonçalves J.E., Oliveira A.J.B., Gonçalves R.A.C., 2017. Morpho-anatomical study of Stevia rebaudiana roots grown in vitro and in vivo. Rev. Bras.de Farmacog., 27, 34-39.

Robbins, R.J., Keck, A.-S., Banuelos, G., \& Finley, J.W., 2005. Cultivation conditions and selenium fertilization alter the phenolic profile, glucosinolate, and sulforaphane content of broccoli. J. of Med. Food, 8(2), 204-214.

Rodrigues, M.A., Afonso, S., Ferreira, I.Q., \& Arrobas, M., 2016. Response of stevia to nitrogen fertilization and harvesting regime in northeastern Portugal. Archives of Agron. and Soil Sci., 1-12.

$\mathbf{S}$

Savita, S.M., Sheela, K., Sunanda, S., 2004. Stevia rebaudiana - A functional component for food Industry. J. Hum. Ecol., 15, 261-264.

Serfaty, M., Ibdah, M., Fischer, R., Chaimovitsh D., Saranga, Y., Dudai, N., 2013. Dynamics of yield components and stevioside production in Stevia rebaudiana grown under different planting times, plant stands and harvest regime. Ind. Crop Prod., 50, 731736.

Shivanna, N., Naika, M., Khanum, F., Kaul, V.K., 2013. Antioxidant, anti-diabetic and renal protective properties of Stevia rebaudiana. J. Diabetes Complic., 27, 103-113.

Shukla, S., Mehta, A., Bajpai, V.K., Shukla, S., 2009. In vitro antioxidant activity and total phenolic content of ethanolic leaf extract of Stevia rebaudiana Bert. Food Chem. Toxicol., 47, 2338-2343. 
Soufi, S., D’Urso G., Pizza C., Rezgui S., Bettaieb T., Montoro P., 2016. Steviol glycosides targeted analysis in leaves of Stevia rebaudiana (Bertoni) from plants cultivated under chilling stress conditions. Food Chem., 190, 572-580.

$\mathbf{T}$

Tadhani, M.B., Patel, V.H., \& Subhash, R., 2007. In vitro antioxidant activities of Stevia rebaudiana leaves and callus. J. of Food Compos. and Anal., 20(3-4), 323-329.

Tavarini, S., Sgherri, C., Ranieri, A.M., \& Angelini, L.G., 2015. Effect of nitrogen fertilization and harvest time on steviol glycosides, flavonoid composition, and antioxidant properties in Stevia rebaudiana Bertoni. J. of Agric. and Food Chem., 63(31), 7041-7050.

Tounekti, T.; Hernández, I.; Müller, M.; Khemira, H.; Munné-Bosch, S., 2011. Kinetin applications alleviate salt stress and improve the antioxidant composition of leaf extracts in Salvia officinalis. Plant Physiol. Biochem., 49, 1165-1176.

\section{V}

Van Acker, S.A.B.E.; De Groot, M.J.; Van den Berg, D.K.; Tromp, M.N.J.L.; den Kelder, G.D.; Van der Vijgh, J.F.; Bast, A.A., 1996. Quantum chemical explanation of the antioxidant activity of flavonoids. Chem. Res. Toxicol., 9, 1305-1312.

\section{W}

Wang, M., Li, H., Xu, F., Gao, X., Li, J., Xu, S., Zhang, D., Wu, X., Xu, J., Hua, H., Li, D., 2018. Diterpenoid lead stevioside and its hydrolysis products steviol and isosteviol: Biological activity and structural modification, Eur. J. of Medic. Chem., 156, 885-906.

Wang, J.; Li, J.; Li, J.; Li, J.; Liu, S.; Huang, L.; Gao, W., 2017. Production of active compounds in medicinal plants: From plant tissue culture to biosynthesis. Chinese Herb. Med., 9, 115-125.

Werner, T.; Motyka, V.; Strnad, M.; Schmülling, T., 2001. Regulation of plant growth by cytokinin. Proc. Natl. Acad. Sci. U.S.A., 98, 10487-10492. 


\section{$\mathbf{Y}$}

Yadav, A.K., Singh, S., Dhyani, D., \& Ahuja, P.S., 2010. A review on the improvement of stevia [Stevia rebaudiana (Bertoni)]. Canad. J. of Plant Science, 91(1), 1-27.

Yang, Y., Huang S., Han Y., Yuan H., Gu, C., Wang Z., 2015. Environmental cues induce changes of steviol glycosides contents and transcription of corresponding biosynthetic genes in Stevia rebaudiana. Plant Phys. and Biochem., 86, 174-180.

Yildiz-Ozturk, E., Nalbantsoy, A., Tag, O., \& Yesil-Celiktas, O., 2015. A comparative study on extraction processes of Stevia rebaudiana leaves with emphasis on antioxidant, cytotoxic and nitric oxide inhibition activities. Ind. Crops and Prod., 77, 961-971.

Yu, H.; Yang, G.; Sato, M.; Yamaguchi, T.; Nakano, T.; Xi, Y., 2017. Antioxidant activities of aqueous extract from Stevia rebaudiana stem waste to inhibit fish oil oxidation and identification of its phenolic compounds. Food Chem., 232, 379-386.

\section{$\mathbf{X}$}

Xi, Y., Yamaguchi, T., Sato, M., Takeuchi, M., 1998. Antioxidant activity of Stevia rebaudiana. J. Japanese Soc. Food Sci. Technol., 45, 310-316

$\mathbf{Z}$

Zhang, Y., Shi, P., Qu, H., Cheng, Y., 2007. Characterization of phenolic compounds in Erigeron breviscapus by liquid chromatography coupled to electrospray ionization mass spectrometry. Rapid Commun. Mass Spectrom., 21, 2971-2984. 
ANNEXES 


\title{
Stevia rebaudiana Bertoni cultivated in Portugal: A prospective study of its antioxidant potential in different conservation conditions
}

\author{
Marisa Barroso ${ }^{\mathrm{a}, \mathrm{b}}$, Lillian Barros ${ }^{\mathrm{a}, \mathrm{c}}, \mathrm{M}^{\mathrm{A}}$. Ângelo Rodrigues ${ }^{\mathrm{a}}$, Maria João Sousa ${ }^{\mathrm{a}}$, \\ Celestino Santos-Buelga ${ }^{\mathrm{c}}$, Isabel C.F.R. Ferreira ${ }^{\mathrm{a}, *}$ \\ a Mountain Research Centre (CIMO), ESA, Polytechnic Institute of Bragança, Campus de Santa Apolónia, 1172, 5301-855 Bragança, Portugal \\ b GIP-USAL, Facultad de Farmacia, Universidad de Salamanca, Campus Miguel de Unamuno, 37007 Salamanca, Spain \\ ${ }^{c}$ Laboratory of Separation and Reaction Engineering - Laboratory of Catalysis and Materials (LSRE-LCM), Polytechnic Institute of Bragança, Campus de \\ Santa Apolónia, 5301-857 Bragança, Portugal
}

\section{A R T I C L E I N F O}

\section{Article history:}

Received 17 February 2016

Received in revised form 6 June 2016

Accepted 9 June 2016

\section{Keywords:}

Stevia

Storage conditions

Tocopherols

Sugars

Phenolic compounds

Antioxidant activity

\begin{abstract}
A B S T R A C T
Studies with well-established cultivation conditions are of utmost importance in order to standardize the plants production and, therefore, its chemical composition. However, the conservation conditions may influence some of the bioactive compounds present in those plants. Stevia rebaudiana Bertoni samples cultivated in the north-eastern of Portugal, were exposed to different conservation conditions (oven-dried at $30^{\circ} \mathrm{C}$, for six days, or kept fresh by freezing $\left(-20^{\circ} \mathrm{C}\right)$ in the same period), and then studied for their antioxidant potential (including antioxidant compounds such as reducing sugars, tocopherols and phenolic compounds, free radical scavenging activity (DPPH) and reducing power (RP)). Oven-dried samples gave the highest antioxidant activity ( DPPH EC $_{50}=22.87 \mu \mathrm{g} / \mathrm{mL}$ and $\mathrm{RP} \mathrm{EC}_{50}=28.79 \mu \mathrm{g} / \mathrm{mL}$ ) and the highest total phenolic compounds concentration. The most abundant phenolic compounds in both samples were two caffeic acid derivatives, 5-O-caffeoylquinic acid (chlorogenic acid) and 3,5-O-dicaffeoylquinic acid. Otherwise, the highest values of total tocopherols and total sugars were registered in frozen fresh samples.

This study gives clues to choose the most appropriate methodology to preserve primary or secondary metabolites of $S$. rebaudiana, involved in its antioxidant activity.
\end{abstract}

(C) 2016 Elsevier B.V. All rights reserved.

\section{Introduction}

The demand for natural sweeteners has been gaining more and more importance due to the great controversy associated with the use of some synthetic sweeteners as cyclamate, aspartame or acesulfame-K. The steviol glycosides (E-960) are a group of natural sweeteners of generalized availability. These compounds are obtained from Stevia rebaudiana Bertoni, a sweet plant native to South America (Carocho et al., 2015), belonging to the Compositae (Asteraceae) family. It is one of the 154 members of the Stevia genus and one of the only two species that produce sweet glycosides (Madan et al., 2010). This plant is also cultivated in China and Southeast Asia (Koyama et al., 2003).

The commercial exploitation of $S$. rebaudiana has become stronger since the 1970 's, after the development in Japan of processes for the extraction and refinement of its leaf sweetener

\footnotetext{
* Corresponding author.

E-mail address: iferreira@ipb.pt (I.C.F.R. Ferreira).
}

(Dacome et al., 2005). The natural sweeteners of $S$. rebaudiana can be 300 times sweeter than sucrose (Gardana et al., 2010) and with the advantages of not being caloric and avoiding high levels of blood sugar (Periche et al., 2015). In addition, S. rebaudiana contains other metabolites with bioactive potential, such as alkaloids, watersoluble chlorophylls, xanthophylls, hydroxycynnamoyl derivatives (caffeoyl and chlorogenic acid derivatives), neutral water-soluble oligosaccharides, free sugars, amino acids, lipids, essential oils and trace elements (Komissarenko et al., 1994). It has also been shown to possess antimicrobial and antioxidant activities (Xi et al., 1998; Tadhani et al., 2007). In vitro antioxidant activity and preventive activity against DNA oxidative damage were reported for crude methanolic and ethyl acetate extracts from $S$. rebaudiana leaves (Ghanta et al., 2007).

Previous studies have shown that stevia leaves contain different antioxidant compounds, such as ascorbic acid (Kim et al., 2011), phenolic compounds (Shukla et al., 2009) including flavonoids (Jahan et al., 2010; Abou-Arab and Abu-Salem, 2010) and tannins (Savita et al., 2004). However, it is important to evaluate if the 
chemical composition of the plant is affected by the conservation process.

In fact, the plants with commercial value are often stored for some time before use and an efficient conservation is very important to avoid the loose of bioactive molecules during this process. One of the main conservation methodologies is drying, which prevents the growth of microorganisms and avoids certain biochemical reactions that may alter the plant organoleptic characteristics (Pinela et al., 2011).

Accordingly, the present work evaluated the effects of dehydration process on the $S$. rebaudiana antioxidant potential, by comparing the free radical scavenging activity, reducing power, and antioxidant compounds of fresh frozen and dried plants. It should be highlighted that the studied samples were obtained in an experimental field with defined cultivation conditions in order to standardize $S$. rebaudiana production and, therefore, chemical composition.

\section{Materials and methods}

\subsection{Cultivation procedure, collection and treatment of the samples}

The field trial supporting this work was carried out in Bragança (41.796742; $-6.761418 ; 750 \mathrm{~m}$ a.s.l.), Northeast Portugal. The region benefits from a Mediterranean type climate, somewhat influenced by the Atlantic regime. Average annual air temperature and annual precipitation for 1971-2000 period were, respectively, $12.3^{\circ} \mathrm{C}$ and $758 \mathrm{~mm}$. The soil is a Regosol of colluvial origin, loamy textured (23.9\% clay, $21.8 \%$ silt, $54.4 \%$ sand), slightly acidic $\left[\mathrm{pH}_{(\mathrm{H} 2 \mathrm{O})}\right.$ 6.3 ], and low in organic carbon (Walkley-Black) $5.6 \mathrm{~g} \mathrm{~kg}^{-1}$. The soil was covered with anti-weed screen punched with holes spaced at $50 \times 40 \mathrm{~cm}$ after the installation of the drip irrigation system. Cuttings of $10-15 \mathrm{~cm}$ height, previously placed on rooting in a greenhouse, were planted in the holes opened in the screen. The cuttings were obtained from a farmer's field grown with cv. Morita. Crop plantation occurred in June 13th, 2014. Plants were watered twice a week throughout the growing season. The harvest took place in August 5th, 2014 and subsamples consisting of three whole plants were separated in fresh in stems and leaves.

After the collection, the specimens (leaves) were separated in two approximately equal halves and placed in paper bags. Half of the samples were dried at $30^{\circ} \mathrm{C}$ (Memmert oven, Edelstahl Rostfrei, Germany) for six days, being designated as oven-dried samples, while the other half was immediately frozen $\left(-20^{\circ} \mathrm{C}\right)$ for the same period, being only lyophilized (FreeZone 4.5, Labconco, Kansas City, MO, USA) before analysis, in order to express the results in dry weight basis to be comparable with the oven-dried samples. These last samples were designated as fresh frozen samples. All the samples were kept in a desiccator and protected from light for subsequent use.

\subsection{Standards and reagents}

HPLC-grade acetonitrile and formic acid were obtained from Lab-Scan (Lisbon, Portugal). Racemic tocol $(50 \mathrm{mg} / \mathrm{mL})$ and tocopherol standards were purchased from Matreya (Pleasant Gap, PA, USA). 2,2-Diphenyl-1-picrylhydrazyl (DPPH) was obtained from Alfa Aesar (Ward Hill, MA, USA). Phenolic compound standards were from Extrasynthèse (Genay, France). Trolox (6-hydroxy2,5,7,8- tetramethylchroman-2-carboxylic acid) and free sugar standards were purchased from Sigma (St. Louis, MO, USA). All other chemicals were of analytical grade and obtained from common chemical suppliers. Water was treated in a Milli-Q water purification system (TGI Pure Water Systems, Greenville, SC, USA).

\subsection{Free sugars}

Free sugars were determined by high-performance liquid chromatography coupled to a refraction index detector (HPLC-RI) after an extraction method described by Barros et al. (2013), using melezitose as internal standard (IS). The equipment consisted of a combined system with a pump (Knauer, Smartline system 1000; Berlin, Germany), degasser system (Smartline manager 5000), auto-sampler (AS-2057 Jasco, Easton, MD) and an RI detector (Knauer Smartline 2300). The chromatographic separation was achieved with a Eurospher 100-5 NH2 column $(4.6 \times 250 \mathrm{~mm}$, $5 \mu \mathrm{m}$, Knauer), operating at $35^{\circ} \mathrm{C}(7971 \mathrm{R}$ Grace oven $)$. The mobile phase used was a mixture of acetonitrile/deionized water, 70:30 $(\mathrm{v} / \mathrm{v})$, at a flow rate of $1 \mathrm{~mL} / \mathrm{min}$. Sugars were identified by chromatographic comparison with standards and quantitation was performed by the IS methodology using a Clarity 2.4 Software (DataApex, Prague, Czech Republic). Results were expressed in $g$ per $100 \mathrm{~g}$ of dry weight $(\mathrm{dw})$.

\subsection{Tocopherols}

Tocopherols were determined after an extraction procedure previously described by Fernandes et al. (2013), using tocol as IS. The analysis was carried out using the HPLC system described above connected to a fluorescence detector (FP-2020; Jasco, Tokyo, Japan) programmed for excitation at $290 \mathrm{~nm}$ and emission at $330 \mathrm{~nm}$. The chromatographic separation was achieved with a Polyamide II normal-phase column $(250 \times 4.6 \mathrm{~mm}, 5 \mu \mathrm{m}$; YMC, Kyoto, Japan $)$, operating at $35^{\circ} \mathrm{C}$. The mobile phase used was a mixture of $n$ hexane and ethyl acetate $(70: 30, \mathrm{v} / \mathrm{v})$ at a flow rate of $1 \mathrm{~mL} / \mathrm{min}$. Tocopherols were identified by chromatographic comparison with standards and quantitation was performed by the IS methodology using a Clarity 2.4 Software. The tocopherols content were expressed in $\mathrm{g}$ per $100 \mathrm{~g}$ of dry weight $(\mathrm{dw})$.

\subsection{Extracts preparation}

Hydroalcoholic extractions were performed by stirring the plant material (leaves) $(1 \mathrm{~g})$ with $30 \mathrm{~mL}$ of methanol/water $(80: 20, \mathrm{v} / \mathrm{v})$ at $25^{\circ} \mathrm{C}$, with a stirring agitation of $150 \mathrm{rpm}$ for $1 \mathrm{~h}$, and filtered through Whatman No. 4 paper. The residue was re-extracted with an additional $30 \mathrm{~mL}$ portion of the hydroalcoholic mixture. The combined extracts were evaporated at $35^{\circ} \mathrm{C}$ under reduced pressure (rotary evaporator Büchi R-210, Flawil, Switzerland) and then further lyophilized.

The lyophilized extracts of both samples were re-dissolved in methanol/water $(80: 20, \mathrm{v} / \mathrm{v}$, final concentration $5 \mathrm{mg} / \mathrm{mL})$, for phenolic compounds determination and antioxidant activity evaluation. The final solutions were further diluted to different concentrations to be submitted to distinct in vitro assays.

\subsection{Phenolic compounds}

The extracts were analysed using a Hewlett-Packard 1100 chromatograph (Agilent Technologies) with a quaternary pump and a diode array detector (DAD) coupled to an HP Chem Station (rev. A.05.04) data-processing station. A Waters Spherisorb S3 ODS-2C $\mathrm{C}_{18}$ ( $4.6 \mathrm{~mm} \times 150 \mathrm{~mm}, 3 \mu \mathrm{m}$; Lisbon, Portugal) column thermostatted at $35^{\circ} \mathrm{C}$ was used for separation. The mobile phase consisted of two solvents: (A) $0.1 \%$ formic acid in water, and (B) acetonitrile, establishing the following elution gradient: $15 \%$ B for $5 \mathrm{~min}, 15 \% \mathrm{~B}$ to $20 \%$ B over $5 \mathrm{~min}, 20-25 \%$ B over $10 \mathrm{~min}, 25-35 \%$ B over $10 \mathrm{~min}$, $35-50 \%$ B for $10 \mathrm{~min}$, and re-equilibration of the column, using a flow rate of $0.5 \mathrm{~mL} / \mathrm{min}$. Double online detection was carried out in the DAD using $280 \mathrm{~nm}$ and $370 \mathrm{~nm}$ as preferred wavelengths and in 
Table 1

Composition of Stevia rebaudiana leaves in tocopherols and free sugars (mean \pm SD).

\begin{tabular}{|c|c|c|c|}
\hline Compounds & Frozen fresh Samples & Oven-dried Samples & t-Students test p-value \\
\hline$\alpha$-Tocopherol & $12.25 \pm 0.08$ & $5.83 \pm 0.01$ & $<0.001$ \\
\hline$\gamma$-Tocopherol & $0.20 \pm 0.01$ & $0.22 \pm 0.01$ & 0.013 \\
\hline$\delta$-Tocopherol & $0.25 \pm 0.01$ & $0.11 \pm 0.01$ & 0.001 \\
\hline Total (mg/100g) & $12.70 \pm 0.10$ & $6.16 \pm 0.02$ & $<0.001$ \\
\hline Ramnose & $0.55 \pm 0.02$ & $0.50 \pm 0.01$ & 0.001 \\
\hline Xylose & $9.76 \pm 0.15$ & $3.81 \pm 0.18$ & $<0.001$ \\
\hline Arabinose + Fructose & $2.04 \pm 0.13$ & $3.30 \pm 0.15$ & $<0.001$ \\
\hline Glucose & $0.26 \pm 0.01$ & $0.040 \pm 0.001$ & $<0.001$ \\
\hline Sucrose & $1.79 \pm 0.16$ & $4.26 \pm 0.17$ & $<0.001$ \\
\hline Trehalose & $0.45 \pm 0.05$ & $0.38 \pm 0.03$ & 0.005 \\
\hline Raffinose & $0.19 \pm 0.04$ & $0.88 \pm 0.04$ & $<0.001$ \\
\hline Total (g/100 g) & $15.04 \pm 0.18$ & $13.17 \pm 0.42$ & $<0.001$ \\
\hline
\end{tabular}

a mass spectrometer (MS) connected to HPLC system via the DAD cell outlet.

MS detection was performed in an API 3200 Qtrap (Applied Biosystems, Darmstadt, Germany) equipped with an ESI source and a triple quadrupole-ion trap mass analyser that was controlled by the Analyst 5.1 software. Zero grade air served as the nebulizer gas (30 psi) and turbo gas for solvent drying $\left(400^{\circ} \mathrm{C}, 40 \mathrm{psi}\right)$. Nitrogen served as the curtain ( $20 \mathrm{psi}$ ) and collision gas (medium). The quadrupols were set at unit resolution. The ion spray voltage was set at $-4500 \mathrm{~V}$ in the negative mode and spectra were recorded between $\mathrm{m} / \mathrm{z} 100$ and 1500. The MS detector was programed for recording in two consecutive modes: enhanced MS (EMS) and enhanced product ion (EPI) analysis. EMS was employed to show full scan spectra, so as to obtain an overview of all of the ions in sample. Settings used were: declustering potential (DP) $-450 \mathrm{~V}$, entrance potential $(\mathrm{EP})-6 \mathrm{~V}$, collision energy $(\mathrm{CE})-10 \mathrm{~V}$. EPI mode was performed in order to obtain the fragmentation pattern of the parent ion(s) in the previous scan using the following parameters: $\mathrm{DP}-50 \mathrm{~V}, \mathrm{EP}-6 \mathrm{~V}, \mathrm{CE}-25 \mathrm{~V}$, and collision energy spread (CES) $0 \mathrm{~V}$.

The phenolic compounds were identified by comparing their retention time, UV-vis and mass spectra with those obtained from standards, when available. Otherwise, peaks were tentatively identified from their absorption and mass spectra and comparison with data reported in the literature. For quantitative analysis, a calibration curve for each available phenolic standard was constructed based on the area of the peak at the detection wavelength used in the HPLC-DAD analysis. For the identified phenolic compounds for which a commercial standard was not available, the quantification was performed through the calibration curve of a compound from the same phenolic group. The results were expressed in $\mathrm{mg} / \mathrm{g}$ of extract.

\subsection{Evaluation of in vitro antioxidant properties}

DPPH radical-scavenging activity was evaluated by using an ELX800 microplate reader (Bio-Tek Instruments, Inc; Winooski, VT, USA). Various concentrations of the extracts $(30 \mu \mathrm{L})$ were mixed with a methanol solution containing DPPH radicals $\left(6 \times 10^{-5} \mathrm{mM}\right.$, $270 \mu \mathrm{L})$ in a 96-well plate and then were left to stand for $60 \mathrm{~min}$ in the dark. The reduction of the DPPH radical was determined by measuring the absorption at $515 \mathrm{~nm}$ and calculated as a percentage of DPPH discoloration using the formula: $\left[\left(A_{D P P H}-A_{S}\right) / A_{D P P H}\right] \times 100$, where $A_{S}$ is the absorbance of the solution containing the sample at $515 \mathrm{~nm}$, and $A_{D P P H}$ is the absorbance of the DPPH solution.

Reducing power was evaluated by the capacity to convert $\mathrm{Fe}^{3+}$ to $\mathrm{Fe}^{2+}$, measuring the absorbance at $690 \mathrm{~nm}$ in the microplate reader mentioned above. Various concentrations of the extracts $(500 \mu \mathrm{L})$ were mixed with sodium phosphate buffer $(\mathrm{pH} 6.6,200 \mathrm{mM}$, $500 \mu \mathrm{L})$ and potassium ferricyanide $(1 \% \mathrm{w} / \mathrm{v}, 500 \mu \mathrm{L})$ in an Eppendorf $(2 \mathrm{~mL})$ and incubated at $50{ }^{\circ} \mathrm{C}$ for $20 \mathrm{~min}$. Trichloroacetic acid
$(10 \%, 500 \mu \mathrm{L})$ was added and then the upper layer $(800 \mu \mathrm{L})$ was mixed with deionised water $(800 \mu \mathrm{L})$ and ferric chloride $(0.1 \%$, $160 \mu \mathrm{L}$ ) in a 48-well plate; the absorbance was further measured at $690 \mathrm{~nm}$. The results were expressed in $\mathrm{EC}_{50}$ values (sample concentration providing $50 \%$ of antioxidant activity or 0.5 of absorbance in the reducing power assay). Trolox was used as standard.

\subsection{Statistical analysis}

Three samples were used for each preparation and all the assays were carried out in triplicate. The results are expressed as mean values and standard deviation (SD). The results were analyzed using a Studentís $t$-test to determine the significant difference among two different samples, with $\alpha=0.05$. This treatment was carried out using SPSS v. 22.0 program (IBM, Armonk, NY, USA).

\section{Results and discussion}

\subsection{Tocopherols and sugars composition}

The tocopherol contents determined in the oven-dried and frozen fresh samples of $S$. rebaudiana are given in Table 1 , with the presence of three isoforms ( $\alpha-, \gamma$ - and $\delta$-tocopherol), being $\alpha$ tocopherol the majority compound in both samples. The highest value of total tocopherols was obtained in the frozen fresh samples, which is in concordance with Pinela et al. (2011), who reported a decrease in tocopherols content in Cytisus and Genista plant species after shade drying. The higher concentration of $\alpha$-tocopherol in frozen fresh samples in comparison with the oven dried ones is also supported by the work of the previously mentioned authors.

Regarding free sugars composition (Table 1), oven-dried and frozen fresh samples revealed the presence of eight different sugars: rhamnose, xylose, arabinose + fructose, glucose, sucrose, trehalose, and raffinose. In general, the highest value of total sugars was registered in frozen fresh samples, mostly due to its higher content of xylose, the major sugar in this sample. It also showed the highest concentration of glucose. No significant differences were obtained for rhamnose and trehalose concentrations. Otherwise and despite the lower value of total sugars, oven-dried samples gave higher concentration of arabinose + fructose, sucrose and raffinose than frozen fresh samples. Pinela et al. (2011) also reported a decrease in free sugars content of plant species from Cytisus genus and Genista genus, after shade drying. Not only free sugars and tocopherols are affected by the drying process but also other important compounds in S. rebaudiana such as steviol glycosides (Periche et al., 2015).

Sucrose was the major free sugar in the oven-dried samples $(4.26 \mathrm{~g} / 100 \mathrm{~g})$, which is in agreement with the results reported by Pereira et al. (2015), who studied a dried and commercial sample of $S$. rebaudiana $(3.93 \mathrm{~g} / 100 \mathrm{~g}$ ). However, the profile obtained was dissimilar between both samples, with the commercial one 
A

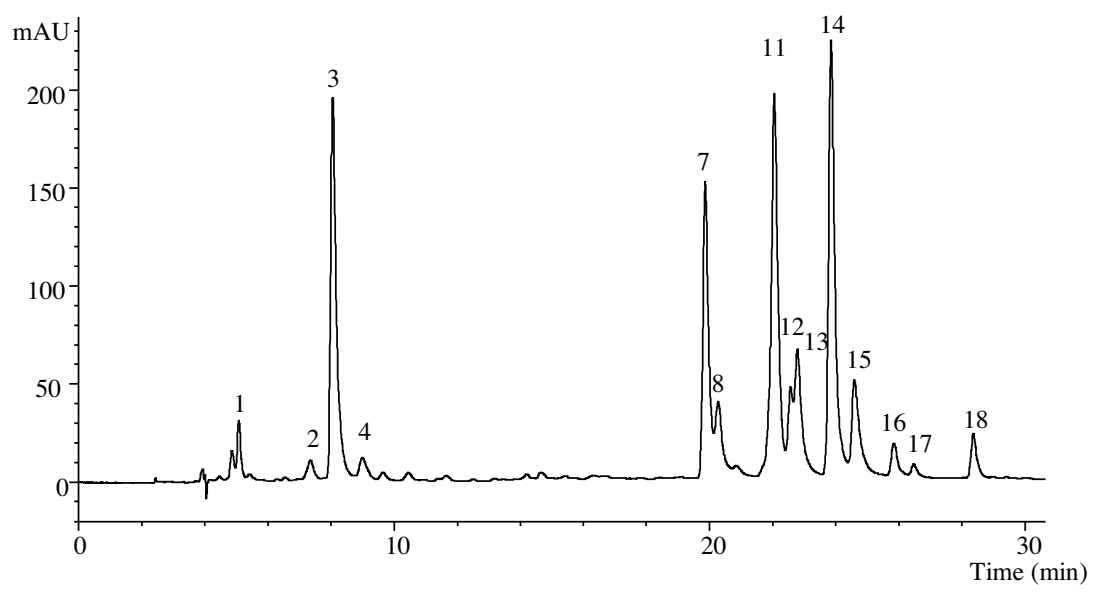

B

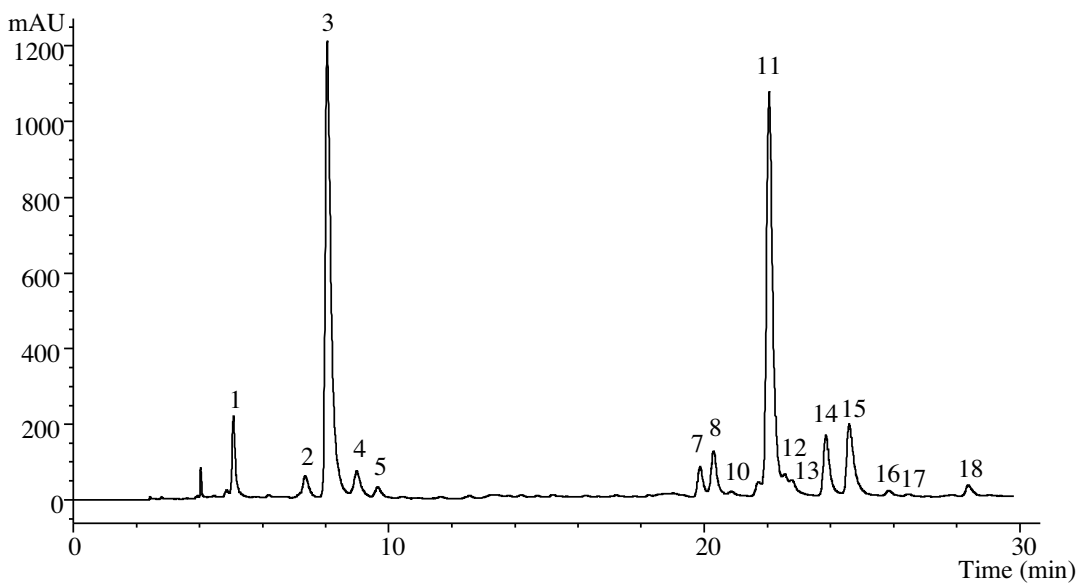

Fig. 1. Phenolic compounds profile of oven-dried Stevia rebaudiana leaves recorded at 370 (A) and 280 (B) $\mathrm{nm}$.

showing only sucrose, fructose, glucose and trehalose. Karimi et al. (2015) also studied soluble sugars in S. rebaudiana, describing an increasing content (mainly glucose) with soil moisture depletion. Fructose and sucrose were also identified by those authors, but in low levels. Indeed, differences in the chemical composition might be related with photoperiod (Ceunen and Geuns, 2013), planting times, plant stands and harvest regime (Serfaty et al., 2013; Karimi et al., 2015). It should be highlighted that the majority of studies in $S$. rebaudiana that are available in literature address to the evaluation of steviol (diterpene compound) glycosides (Brandle and Telmer 2007; Gardana et al., 2010; Geuns et al., 2003; Periche et al., 2015), the responsible for the sweet taste of this plant, and not the herein studied free sugars.

\subsection{Phenolic composition}

The phenolic compounds profile of the hydroalcoholic extract of $S$. rebaudiana leaves is shown in Fig. 1. Data (retention time, $\lambda_{\max }$ in the visible region, pseudomolecular ion and main fragment ions observed in $\mathrm{MS}^{2}$ ) obtained by HPLC-DAD-ESI/MS analysis regarding phenolic compounds identification and individual quantification are presented in Table 2. Compounds 3, 6, 7 and 10 were positively identified as 5-O-caffeoylquinic acid, quercetin-3-O-rutinoside, quercetin-3-O-glucoside and kaempferol-3-O-glucoside respectively, by comparison with authentic standards and analysis of their MS fragmentation pattern, retention time and UV-vis characteris- tics. The presence of these compounds has already been reported in S. rebaudiana by different authors (Cacciola et al., 2011; Muanda et al., 2011; Karakose et al., 2011, 2015; Shivanna et al., 2013; Barba et al., 2015; Gaweł-Bęben et al., 2015).

Compounds 1 and $2\left([\mathrm{M}-\mathrm{H}]^{-}\right.$at $\left.m / z 353\right)$ were identified as 3-O-caffeoylquinic acid and 4-O-caffeoylquinic acid based on the fragmentation pattern and characteristics reported by Clifford et al. (2003, 2005). Peaks 8, 11 and $15\left([\mathrm{M}-\mathrm{H}]^{-}\right.$at $\mathrm{m} / z$ 515) could be assigned as 3,4-O-, 3,5-O- and 4,5-O-dicaffeoylquinic acids, respectively, based on their elution order, fragmentation pattern and relative abundances (Clifford et al., 2003, 2005). All those compounds have also been described in S. rebaudiana (Muanda et al., 2011; Karakose et al., 2011, 2015; Shivanna et al., 2013), also confirming their identification in this sample. Peaks $4\left([\mathrm{M}-\mathrm{H}]^{-}\right.$at $m / z$ $381)$ and $5\left([\mathrm{M}-\mathrm{H}]^{-}\right.$at $\left.m / z 391\right)$ presented a fragmentation pattern and UV-vis spectra similar to caffeic acid. Compounds showing a pseudomolecular ion at $m / z 381$ were detected in other Asteraceae like Erigeron breviscapus and identified as caffeoyl-2,7-anhydro-3deoxy-2-octulopyranosonic acids (Zhang et al., 2007; Liao et al., 2010), identity that was tentatively assumed for the compound 4 detected herein. No structure could, however, be matched for peak 5 that remained unidentified as a caffeic acid derivative.

The rest of phenolic compounds were assigned to flavonol derivatives based on their characteristic UV spectra showing maximum wavelength of absorption $\left(\lambda_{\max }\right)$ around $345-360 \mathrm{~nm}$ and the release of $\mathrm{MS}^{2}$ fragment ions at $\mathrm{m} / \mathrm{z} 301$ (quercetin) or 285 
Table 2

Phenolic compounds identification and quantification in Stevia rebaudiana leaves.

\begin{tabular}{|c|c|c|c|c|c|c|c|c|}
\hline \multirow[t]{2}{*}{ Compounds } & \multirow[t]{2}{*}{$\operatorname{Rt}(\min )$} & \multirow[t]{2}{*}{$\lambda_{\max (\mathrm{nm})}$} & \multirow{2}{*}{$\begin{array}{l}\text { Pseudomolecular } \\
\text { ion }[\mathrm{M}-\mathrm{H}]^{-} \\
(m / z)\end{array}$} & \multirow[t]{2}{*}{$\operatorname{MS}^{2}(m / z)$} & \multirow[t]{2}{*}{ Tentative identification } & \multicolumn{2}{|c|}{ Quantification (mg/g extract) } & \multirow{2}{*}{$\begin{array}{l}t \text {-Students test } \\
p \text {-value }\end{array}$} \\
\hline & & & & & & $\begin{array}{l}\text { Frozen fresh } \\
\text { samples }\end{array}$ & $\begin{array}{l}\text { Oven-dried } \\
\text { samples }\end{array}$ & \\
\hline 1 & 5.1 & 328 & 353 & 191(100),179(45),161(6),135(66) & 3-O-Caffeoylquinic acid & $1.79 \pm 0.03$ & $5.54 \pm 0.03$ & $<0.001$ \\
\hline 2 & 7.2 & 328 & 353 & 191(72),179(80),173(100),161(9),135(77) & 4-O-Caffeoylquinic acid & $1.48 \pm 0.01$ & $2.85 \pm 0.01$ & $<0.001$ \\
\hline 3 & 7.9 & 328 & 353 & 191(100),179(3),161(6),135(4) & 5-O-Caffeoylquinic acid & $27.85 \pm 0.05$ & $51.0 \pm 0.2$ & $<0.001$ \\
\hline 4 & 8.7 & 328 & 381 & $179(35), 161(100), 135(33)$ & $\begin{array}{l}\text { Caffeoyl-2,7-anhydro-3-deoxy- } \\
\text { 2-octulopyranosonic } \\
\text { acid }\end{array}$ & $0.22 \pm 0.01$ & $2.82 \pm 0.02$ & $<0.001$ \\
\hline 5 & 9.5 & 320 & 391 & $217(50), 179(38), 135(63)$ & Caffeic acid derivative & $0.20 \pm 0.02$ & $0.84 \pm 0.05$ & $<0.001$ \\
\hline 6 & 19.0 & 354 & 609 & $301(100)$ & Quercetin-3-O-rutinoside & $4.32 \pm 0.01$ & nd & - \\
\hline 7 & 20.2 & 354 & 463 & $301(100)$ & Quercetin-3-O-glucoside & $0.51 \pm 0.01$ & $5.38 \pm 0.04$ & $<0.001$ \\
\hline 8 & 20.7 & 328 & 515 & $353(87), 335(45), 191(41), 179(76), 173(91), 161(17), 135(25)$ & 3,4-O-Dicaffeoylquinic acid & $1.24 \pm 0.04$ & $5.52 \pm 0.03$ & $<0.001$ \\
\hline 9 & 21.0 & 358 & 579 & $301(100)$ & $\begin{array}{l}\text { Quercetin-O-pentosyl- } \\
\text { deoxyhexoside }\end{array}$ & $1.08 \pm 0.02$ & nd & - \\
\hline 10 & 21.3 & 348 & 447 & $285(100)$ & Kaempferol-3-O-glucoside & $2.10 \pm 0.02$ & $0.39 \pm 0.03$ & $<0.001$ \\
\hline 11 & 22.4 & 328 & 515 & 353(90),335(8),191(100),179(89),173(14),161(8),135(46) & 3,5-O-Dicaffeoylquinic acid & $18.1 \pm 0.1$ & $49.2 \pm 0.2$ & $<0.001$ \\
\hline 12 & 23.1 & 350 & 447 & $285(100)$ & Kaempferol-O-hexoside & nd & $2.1 \pm 0.1$ & - \\
\hline 13 & 23.3 & 358 & 433 & $301(100)$ & Quercetin-3-O-xyloside & $2.2 \pm 0.1$ & $2.97 \pm 0.01$ & 0.007 \\
\hline 14 & 24.3 & 350 & 447 & $301(100)$ & Quercetin-3-O-rhamnoside & $9.84 \pm 0.03$ & $9.29 \pm 0.03$ & 0.001 \\
\hline 15 & 25.0 & 328 & 515 & 353(81),335(3),191(21),179(73),173(100),135(21) & 4,5-O-Dicaffeoylquinic acid & $2.95 \pm 0.04$ & $10.83 \pm 0.05$ & $<0.001$ \\
\hline 16 & 26.4 & 350 & 417 & $285(100)$ & Kaempferol-O-pentoside & $1.35 \pm 0.01$ & $1.03 \pm 0.01$ & $<0.001$ \\
\hline 17 & 27.1 & 350 & 417 & $285(100)$ & Kaempferol-O-pentoside & $0.29 \pm 0.01$ & $0.35 \pm 0.01$ & 0.015 \\
\hline \multirow[t]{4}{*}{18} & 29.0 & 346 & 431 & $285(100)$ & Kaempferol-O-deoxyhexoside & $1.58 \pm 0.02$ & $1.20 \pm 0.02$ & 0.001 \\
\hline & & & & & Total phenolic acid derivatives & $53.8 \pm 0.1$ & $128.5 \pm 0.4$ & $<0.001$ \\
\hline & & & & & Total flavonoids & $23.3 \pm 0.1$ & $22.7 \pm 0.2$ & 0.029 \\
\hline & & & & & Total phenolic compounds & $77.1 \pm 0.2$ & $151 \pm 1$ & $<0.001$ \\
\hline
\end{tabular}




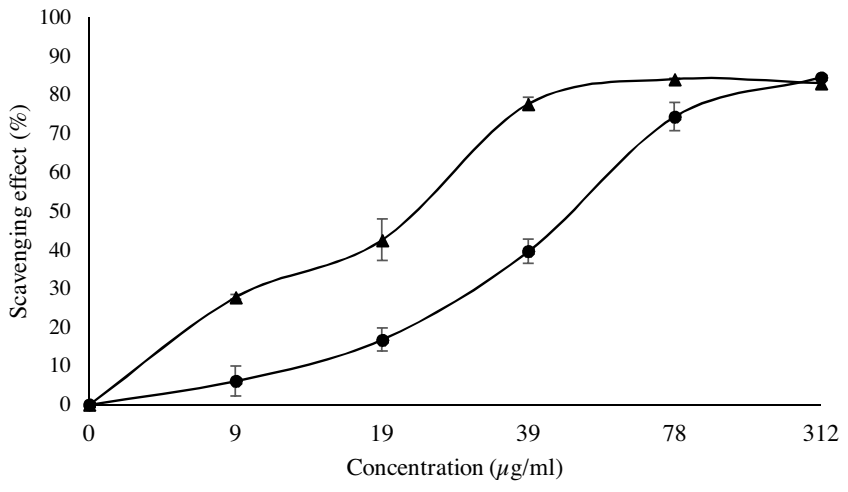

Fig. 2. Percentage of scavenging activity on DPPH radicals in extracts of frozen fresh $(-)$ ) and oven-dried samples ( $\square$ ) of Stevia rebaudiana. $\mathrm{EC}_{50}$ : extract concentration corresponding to $50 \%$ of DPPH scavenging activity. Frozen fresh samples: $\mathrm{EC}_{50}=50.66 \pm 3.64 \mu \mathrm{g} / \mathrm{mL}$; oven-dried samples: $\mathrm{EC}_{50}=22.87 \pm 2.17 \mu \mathrm{g} / \mathrm{mL}$.

(kaempferol). Peaks 9, 13 and $14\left([\mathrm{M}-\mathrm{H}]^{-}\right.$at $\mathrm{m} / \mathrm{z}$ 579, 433 and 447 , respectively) were assigned to quercetin glycosides, and peaks $12\left([\mathrm{M}-\mathrm{H}]^{-}\right.$at $\left.m / z 447\right), 16$ and $17\left([\mathrm{M}-\mathrm{H}]^{-}\right.$at $\left.\mathrm{m} / \mathrm{z} 417\right)$, and 18 $\left([\mathrm{M}-\mathrm{H}]^{-}\right.$at $\left.m / z 431\right)$ to kaempferol derivatives. They presented MS $^{2}$ fragments corresponding to distinct losses of hexosyl $(-162 \mathrm{u})$, deoxyhexosyl $(-146 \mathrm{u})$ or pentosyl $(-132 \mathrm{u})$ residues, although mass spectral characteristics did not allow characterising the position and nature of the sugar moieties. Similar compounds have already been reported in leaves of $S$. rebaudiana (Cacciola et al., 2011; Muanda et al., 2011; Karakose et al., 2015; Shivanna et al., 2013). Among them, peaks 13 and 14 might be tentatively associated to quercetin-3-O-xyloside and quercetin-3-O-rhamnoside, previously identified in leaves of $S$. rebaudiana by Shivanna et al. (2013) and Cacciola et al. (2011), respectively.

The most abundant phenolic compounds in the studied samples were 5-O-caffeoylquinic acid (chlorogenic acid) and 3,5$O$-dicaffeoylquinic acid. Oven-dried samples presented the highest total phenolic compounds concentration, due to the presence of higher concentration of phenolic acids, whereas the concentration of total flavonoids in both samples is similar. As for the qualitative composition, oven-dried samples did not reveal the presence of quercetin-3-O-rutinoside (rutin) and quercetin-Opentosyl-deoxyhexoside, while the frozen fresh sample did not present peak 12 (kaempferol-O-hexoside).

\subsection{Antioxidant activity}

Figs. 2 and 3 show the results obtained in the antioxidant activity evaluation of $S$. rebaudiana extracts, measured by the DPPH radical scavenging activity (RSA) and reducing power (RP) assays, respectively. The extracts from oven-dried samples gave higher RSA and RP (i.e., lower $\mathrm{EC}_{50}$ values of $22.87 \mu \mathrm{g} / \mathrm{mL}$ and $28.79 \mu \mathrm{g} / \mathrm{mL}$, respectively) than those of frozen fresh samples $(50.66 \mu \mathrm{g} / \mathrm{mL}$ and $39.73 \mu \mathrm{g} / \mathrm{mL}$ ), which is in disagreement with other authors (Pinela et al., 2011), that reported a higher antioxidant activity in frozen fresh samples of four shrubby flowering plants widely consumed in folk medicine. However, our results are in accordance with the contents of phenolic compounds observed in both samples, once the extract of the oven-dried samples possessed higher concentration of total phenolic compounds (Table 2). Other authors have reported the high potential of $S$. rebaudiana leaves as a natural antioxidant, with associated health benefits (Xi et al., 1998; Tadhani et al., 2007; Jahan et al., 2010; Kim et al., 2011).

S. rebaudiana is widely known for its natural sweeteners content, although this plant could also be considered as a good source of antioxidants, such as phenolic compounds. However, appropriate methodologies have to be applied to preserve the chemical

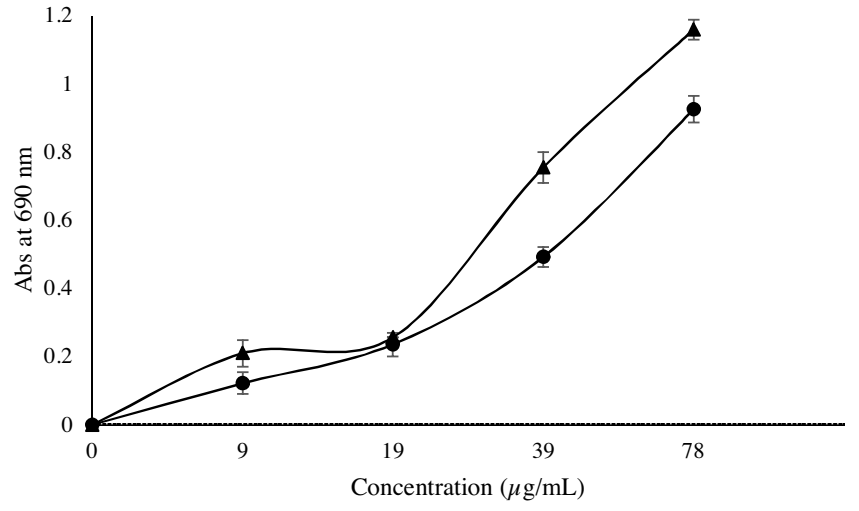

Fig. 3. Reducing power in extracts of frozen fresh ( $\rightarrow-$ ) and oven-dried samples $(\longrightarrow-$ ) of Stevia rebaudiana (higher absorbance indicates higher reducing power). $\mathrm{EC}_{50}$ : extract concentration corresponding to 0.5 of absorbance. Frozen fresh samples: $\mathrm{EC}_{50}=39.73 \pm 0.10 \mu \mathrm{g} / \mathrm{mL}$; oven-dried samples: $\mathrm{EC}_{50}=28.79 \pm 0.09 \mu \mathrm{g} / \mathrm{mL}$.

constituents of S. rebaudiana. This study proved that oven-dried samples showed higher antioxidant activity and phenolic compounds contents than frozen fresh samples, whereas these latter possessed higher levels of tocopherols and free sugars. Overall, it is very important to establish suitable conditions to cultivate S. rebaudiana in order to standardize its chemical composition, but not least important is the preservation process selected for this plant.

\section{Acknowledgments}

The authors are grateful to the Foundation for Science and Technology (FCT, Portugal) and FEDER under Programe PT2020 for financial support to CIMO (UID/AGR/00690/2013), LSRE (Project UID/EQU/50020/2013) and L. Barros (SFRH/BPD/107855/2015) grant.

\section{References}

Abou-Arab, E.A., Abu-Salem, F.M., 2010. Evaluation of bioactive compounds of Stevia rebaudiana leaves and callus. Afr. J. Food Sci. 4, 627-634.

Barba, F.J., Grimi, N., Vorobiev, E., 2015. Evaluating the potential of cell disruption technologies for green selective extraction of antioxidant compounds from Stevia rebaudiana Bertoni leaves. J. Food Eng. 149, 222-228.

Barros, L., Pereira, E., Calhelha, R.C., Dueñas, M., Carvalho, A.M., Santos-Buelga, C., Ferreira, I.C.F.R., 2013. Bioactivity and chemical characterization in hydrophilic and lipophilic compounds of Chenopodium ambrosioides L. J. Funct. Food. 5, 1732-1740.

Brandle, J.E., Telmer, P.G., 2007. Steviol glycoside biosynthesis. Phytochemistry 68 1855-1863.

Cacciola, F., Delmonte, P., Jaworska, K., Dugo, P., Mondello, L., Rader, J.I., 2011. Employing ultra high pressure liquid chromatography as the second dimension in a comprehensive two-dimensional system for analysis of Stevia rebaudiana extracts. J. Chromatogr. A 1218, 2012-2018.

Carocho, M., Morales, P., Ferreira, I.C.F.R., 2015. Natural food additives: Quo vadis? Trends Food Sci. Technol. 45, 284-295.

Ceunen, S., Geuns, J.M.C., 2013. Influence of photoperiodism on the spatio-temporal accumulation of steviol glycosides in Stevia rebaudiana (Bertoni). Plant Sci. 198, 72-82.

Clifford, M.N., Johnston, K.L., Knight, S., Kuhnert, N.A., 2003. A hierarchical scheme for LC-MS ${ }^{\mathrm{n}}$ identification of chlorogenic acids. J. Agric. Food Chem. 51, 2900-2911.

Clifford, M.N., Knight, S., Kuhnert, N.A., 2005. Discriminating between the six isomers of dicaffeoylquinic acid by LC-MSn . J. Agric. Food Chem. 53, 3821-3832.

Dacome, A.S., Silva, C.C., Costa, C.E.M., Fontana, J.D., Adelmann, J., Costa, S.C., 2005. Sweet diterpenic glycosides balance of a new cultivar of Stevia rebaudiana (Bert) Bertoni: isolation and quantitative distribution by chromatographic, spectroscopic and electrophoretic methods. Process Biochem. 44, 3587-3594.

Fernandes, Â., Barreira, J.C.M., António, A.L., Santos, P.M.P., Martins, A., Oliveira, M.B.P.P., Ferreira, I.C.F.R., 2013. Study of chemical changes and antioxidant activity variation induced by gamma-irradiation on wild mushrooms: comparative study through principal component analysis. Food Res. Int. 54, $18-25$.

Gardana, C., Scaglianti, M., Simonetti, P., 2010. Evaluation of steviol and its glycosides in Stevia rebaudiana leaves and commercial sweetener by 
ultra-high-performance liquid chromatography-mass spectrometry. J. Chromatogr. A 1217, 1463-1470.

Gaweł-Bęben, K., Bujak, T., Nizioł-Łukaszewska, Z., Antosiewicz, B., Jakubczyk, A., Karaś, M., Rybczyńska, K., 2015. Stevia rebaudiana Bert. leaf extracts as a multifunctional source of natural antioxidants. Molecules 20, 5468-5486.

Geuns, J.M.C., Augustijns, P., Mols, R., 2003. Metabolism of stevioside in pigs and intestinal absorption characteristics of stevioside, rebaudioside A and steviol. Food Chem. Toxicol. 41, 1599-1607.

Ghanta, S., Banerjee, A., Poddar, A., Chattopadhyay, S., 2007. Oxidative DNA damage preventive activity and antioxidant potential of Stevia rebaudiana (Bertoni) Bertoni, a natural sweetener. J. Agric. Food Chem. 55, 10962-10967.

Jahan, I.A., Mostafa, M., Hossain, H., Nimmi, I., Sattar, A., Alim, A., Moeiz, S.M.I., 2010. Antioxidant activity of Stevia rebaudiana Bert, leaves from Bangladesh. Bangladesh Pharm. J. 13, 67-75.

Karakose, H., Jaiswal, R., Kuhnert, N., 2011. Characterization and quantification of hydroxycinnamate derivatives in Stevia rebaudiana leaves by LC-MS ${ }^{\mathrm{n}}$. J. Agric Food Chem. 59, 10143-10150.

Karakose, H., Muller, A., Kuhnert, N., 2015. Profiling and quantification of phenolics in Stevia rebaudiana leaves. J. Agric. Food Chem. 63, 9188-9198.

Karimi, M., Ahmadi, A., Hashemi, J., Abbasi, A., Tavarini, S., Guglielminetti, L., Angelini, L.G., 2015. The effect of soil moisture depletion on Stevia (Stevia rebaudiana Bertoni) grown in greenhouse conditions: growth, steviol glycosides content, soluble sugars and total antioxidant capacity. Sci. Hort. 183, 93-99.

Kim, I., Yang, M., Lee, O., Kang, S., 2011. The antioxidant activity and the bioactive compound content of Stevia rebaudiana water extracts. Food Sci. Technol. 44, 1328-1332.

Komissarenko, N.F., Derkach, A.I., Kovalyov, I.P., Bublik, N.P., 1994. Diterpene glycosides and phenylpropanoids of Stevia rebaudiana Bertoni. Rastitel'Nye Resursy 1, 53-64.

Koyama, E., Kitazawa, K., Ohori, Y., Izawa, O., Kakegawa, K., Fujino, A., Ui, M., 2003. In vitro metabolism of the glycosidic sweeteners, stevia mixture and enzymatically modified Stevia in human intestinal microflora. Food Chem. Toxicol. 41, 359-374

Liao, S.-G., Zhang, L.-J., Li, C.-B., Lan, Y.-Y., Wang, A.-M., Huang, Y., Zhen, L., Fu, X.-Z., Zhou, W., Qi, X.-L., Guan, Z.-Z., Wang, Y.-L., 2010. Rapid screening and identification of caffeic acid and its esters in Erigeron breviscapus by ultra-performance liquid chromatography/tandem mass spectrometry. Rapid Commun. Mass Spectrom. 24, 2533-2541.

Madan, S., Ahmad, S., Singh, G.N., Kohli, K., Kumar, Y., Singh, R., Garg, M., 2010. Stevia rebaudiana (Bert.) bertoni-a review. Indian J. Nat. Prod. Res. 1, 267-286.

Muanda, F.N., Soulimani, R., Diop, B., Dicko, A., 2011. Study on chemical composition and biological activities of essential oil and extracts from Stevia rebaudiana Bertoni leaves. Food Sci.Technol. 44, 1865-1872.

Pereira, C., Barros, L., Ferreira, I.C.F.R., 2015. A comparison of the nutritional contribution of thirty-nine aromatic plants used as condiments and/or herbal infusions. Plant Foods Hum. Nutr. 70, 176-183.

Periche, A., Castelló, M.L., Escriche, I., 2015. Influence of drying method on steviol glycosides and antioxidants in Stevia rebaudiana leaves. Food Chem. 173, 1-6.

Pinela, J., Barros, L., Carvalho, A.M., Ferreira, I.C.F.R., 2011. Influence of the drying method in the antioxidant potential of four shrubby flowering plants from the tribe Genisteae (Fabaceae). Food Chem. Toxicol. 49, 2983-2989.

Savita, S.M., Sheela, K., Sunanda, S., 2004. Stevia rebaudiana-a functional component for food Industry. J. Hum. Ecol. 15, 261-264.

Serfaty, M., Ibdah, M., Fischer, R., Chaimovitsh, D., Saranga, Y., Dudai, N., 2013. Dynamics of yield components and stevioside production in Stevia rebaudiana grown under different planting times, plant stands and harvest regime. Ind. Crop Prod. 50, 731-736.

Shivanna, N., Naika, M., Khanum, F., Kaul, V.K., 2013. Antioxidant, anti-diabetic and renal protective properties of Stevia rebaudiana. J. Diabetes Complications 27, 103-113.

Shukla, S., Mehta, A., Bajpai, V.K., Shukla, S., 2009. In vitro antioxidant activity and total phenolic content of ethanolic leaf extract of Stevia rebaudiana Bert. Food Chem. Toxicol. 47, 2338-2343.

Tadhani, M., Patel, V., Subhash, R., 2007. In vitro antioxidant activities of Stevia rebaudiana leaves and callus. J. Food Com. Anal. 20, 323-329.

Xi, Y., Yamaguchi, T., Sato, M., Takeuchi, M., 1998. Antioxidant activity of Stevia rebaudiana. J. Japanese Soc. Food Sci. Technol. 45, 310-316.

Zhang, Y., Shi, P., Qu, H., Cheng, Y., 2007. Characterization of phenolic compounds in Erigeron breviscapus by liquid chromatography coupled to electrospray ionization mass spectrometry. Rapid Commun. Mass Spectrom. 21, 2971-2984 



\title{
Assessment of the nitrogen fertilization effect on bioactive compounds of frozen fresh and dried samples of Stevia rebaudiana Bertoni
}

\author{
Marisa R. Barroso $^{\mathrm{a}, \mathrm{b}}$, Natália Martins ${ }^{\mathrm{a}}$, Lillian Barros ${ }^{\mathrm{a}, *}$, Amilcar L. Antonio ${ }^{\mathrm{a}}$, \\ M. Ângelo Rodrigues ${ }^{\mathrm{a}}$, Maria João Sousa ${ }^{\mathrm{a}}$, Celestino Santos-Buelga ${ }^{\mathrm{b}}$, Isabel C.F.R. Ferreira ${ }^{\mathrm{a}, *}$ \\ a Centro de Investigação de Montanha (CIMO), Instituto Politécnico de Bragança, Campus de Santa Apolónia, 5300-253 Bragança, Portugal \\ b Grupo de Investigación en Polifenoles (GIP-USAL), Facultad de Farmacia, Universidad de Salamanca, Campus Miguel de Unamuno s/n, 37007 Salamanca, Spain
}

\section{A R T I C L E I N F O}

\section{Keywords:}

Stevia rebaudiana Bertoni

Chemical composition

Phenolic compounds

Nitrogen fertilization

Antioxidant activity

\begin{abstract}
A B S T R A C T
The present study aims to assess the effect of different nitrogen $(\mathrm{N})$ rates on the chemical composition and antioxidant properties of stevia frozen fresh and dried leaves, and to define the best growing conditions to maximize the levels of bioactive compounds. In general, processing affects more significantly the tocopherol and sugar contents than $\mathrm{N}$ fertilization. The most abundant sugars were xylose, arabinose + fructose and sucrose, presenting dried samples with higher contents than frozen fresh ones, while the latter better retained tocopherols than dry samples. Regarding phenolic compounds, greater levels were found in dried samples and in those fertilized with $25 \mathrm{~kg} \mathrm{Nha}^{-1}$. Leaves from plants fertilized with 25 and $50 \mathrm{~kg} \mathrm{~N}^{-1}$ also evidenced higher antioxidant activity, which seemed to be influenced by the phenolic composition. In general, $\mathrm{N}$ fertilization provides an improvement in the chemical composition and bioactive potential of stevia leaves.
\end{abstract}

\section{Introduction}

Stevia rebaudiana Bertoni, widely known as Sweet-Leaf is an herbaceous perennial shrub, that occurs naturally in South America, but nowadays it is widely cultivated and mostly used as a sweetener in many parts of the world (Gupta, Purwar, Sundaram, \& Rai, 2013). The reason why this plant is being used as a source of natural sweetener is due to its high content in sweet diterpene glycosides, including isosteviol, stevioside, rebaudiosides (A, B, C, D, E and F), steviolbioside and dulcoside A (Goyal, Samsher, \& Samsher, 2010; Rajasekaran, Ramakrishna, Sankar, Giridhar, \& Ravishankar, 2008). The natural sweeteners of $S$. rebaudiana can be 300 times sweeter than sucrose (Gardana, Scaglianti, \& Simonetti, 2010). Beside glycosides, the leaves of stevia also contain other phytochemicals, such as flavonoids, phenolic acids, fatty acids, proteins and vitamins (Gupta et al., 2013). Several studies have reported that stevia extracts exert significant antimicrobial, anti-hypertensive, antitumor, anti-inflammatory, hepatoprotective and immunomodulatory activities, with those biological effects being closely related to its high abundance in bioactive phytoconstituents (Tadhani, Patel, \& Subhash, 2007; Yildiz-Ozturk, Nalbantsoy, Tag, \& Yesil-Celiktas, 2015; Álvarez-Robles, López-Orenes, Ferrer, \& Calderón, 2016).

It is known that the chemical and biological diversity of $S$. rebaudiana are influenced by several factors, like genotype, phenological stage and growth conditions (Brandle \& Rosa, 1992; Brandle, Starratt, \& Gijzen, 1998; Yadav, Singh, Dhyani, \& Ahuja, 2011). However, there is a lack of information about the real effects of fertilization on the chemical and bioactive properties of stevia plants. In fact, $\mathrm{N}$, phosphorous (P) and potassium (K) fertilization, as well as plant status, display an important role in defining the final concentration of secondary metabolites and, therefore, biological potential (Aires, Rosa, \& Carvalho, 2006). Among them, $\mathrm{N}$ is considered as being one of the most important essential elements in plant science, being used by plants to synthesize many organic compounds, such as amino acids, proteins, enzymes and nucleic acids (Koeduka et al., 2006). Beyond this, $\mathrm{N}$ also has other functions in plant life, such as those related with biomass yield (Rodrigues, Afonso, Ferreira, \& Arrobas, 2016); presently, it was confirmed that high rates of $\mathrm{N}$ increase both the number and size of leaf cells (Yadav et al., 2011). Regarding bioactive constituents, and despite the existence of conflicting results, it has been shown that $\mathrm{N}$ availability not only influences the secondary metabolites production in a predictable manner, but also plant growth and differentiation processes (Aires et al., 2006; Ibrahim, Jaafar, Rahmat, \& Rahman, 2011). Thus, it becomes increasingly evident that different $\mathrm{N}$ rates influence the biosynthesis of active constituents by cultivated medicinal plants (Karimi, Jaafar, \& Ahmad, 2013; Tavarini, Sgherri, Ranieri, \& Angelini, 2015). For example, Tavarini et al. (2015) observed that both $\mathrm{N}$ fertilization and harvest time exert a pronounced influence on

\footnotetext{
* Corresponding authors.

E-mail addresses: lillian@ipb.pt (L. Barros), iferreira@ipb.pt (I.C.F.R. Ferreira).
} 
phytochemical composition and antioxidant activity of stevia. A similar scenario was also observed in Labisia pumila (Benth. \& Hook) indicating that the manipulation of $\mathrm{N}$ fertilization levels may be an effective method to improve the expression of secondary metabolites (Ibrahim et al., 2011). However, in general, research is overlooking the fact that the availability of $\mathrm{N}$ might be a determinant/important factor on secondary metabolism in medicinal and aromatic plants.

Thus, and considering the importance of bioactive compounds in $S$. rebaudiana, the present study aims to assess the effect of different $\mathrm{N}$ rates on the chemical composition of stevia frozen fresh and dried leaves, and to define the best growing conditions to maximize the levels of these compounds.

\section{Materials and methods}

\subsection{Cultivation procedure, collection and treatment of the samples}

The field trial supporting this study was carried out in the Vilariça region (41.191373; - 7.103809), NE Portugal, which benefits from a Mediterranean climate. The mean annual temperature and accumulated precipitation in the period from 1971 to 2000 were, respectively, $14.3{ }^{\circ} \mathrm{C}$ and $509 \mathrm{~mm}$. The field trial was established in a Fluvisol, loam textured (16.1\% clay, $41.3 \%$ silt, $42.6 \%$ sand), $\mathrm{pH}\left(\mathrm{H}_{2} \mathrm{O}\right) 6.1$, organic carbon $9.9 \mathrm{~g} \mathrm{~kg}^{-1}$ and extractable (Egner-Rhiem) $\mathrm{P}\left(\mathrm{P}_{2} \mathrm{O}_{5}\right)$ and $\mathrm{K}\left(\mathrm{K}_{2} \mathrm{O}\right)$ at 39.5 and $240 \mathrm{mg} \mathrm{kg}^{-1}$, respectively. The field trial included four $\mathrm{N}$ rates [0 (N0), 25 (N1), $50(\mathrm{~N} 2), 100(\mathrm{~N} 3) \mathrm{kg} \mathrm{N} \mathrm{ha}^{-1}$ ] and was arranged as a completely randomized design, with three replications. $\mathrm{N}$ was supplied as an organic amendment containing 6\% N, 3\% P $\left(\mathrm{P}_{2} \mathrm{O}_{5}\right)$ and $2 \% \mathrm{~K}\left(\mathrm{~K}_{2} \mathrm{O}\right)$. A drip irrigation system was installed after soil preparation and covered with an anti-weed screen. Plants were grown in holes made in the screen spaced at $50 \times 40 \mathrm{~cm}$. The cuttings, previously rooted in a greenhouse, were planted on June 13 th 2014, and the harvest took place on August 5th 2014.

After collection, specimens were separated into two similar halves and placed in paper bags. Half of the samples were dried at $30^{\circ} \mathrm{C}$ (Memmert oven, Edelstahl Rostfrei, Germany) for six days, while the other half was immediately frozen and kept at $-20{ }^{\circ} \mathrm{C}$ for the same period before being lyophilized (FreeZone 4.5, Labconco, Kansas City, MO, USA). All the samples were reduced to a fine powder ( $\sim 20$ mesh) and stored in a desiccator protected from light for subsequent assays.

\subsection{Free sugars}

Free sugars were determined by HPLC coupled to a RI detector (Knauer, Smartline system 1000, Berlin, Germany) using the internal standard (IS, melezitose) method, as previously described by the authors (Barroso et al., 2016). Mobile phase consisted of acetonitrile:water mixture $(70: 30 \mathrm{v} / \mathrm{v}$, acetonitrile HPLC-grade, Lab-Scan, Lisbon, Portugal) and separation was achieved using a Eurospher 100-5 NH2 column $(4.6 \times 250 \mathrm{~mm}, 5 \mu \mathrm{m}$, Knauer). Results (Clarity 2.4 software, DataApex, Prague, Czech Republic) were expressed in $\mathrm{g}$ per $100 \mathrm{~g}$ of dry weight (dw).

\subsection{Tocopherols}

Tocopherols were determined following a procedure previously described by Barroso et al. (2016), using a HPLC system (Knauer, Smartline system 1000, Berlin, Germany) coupled to a fluorescence detector (FP-2020; Jasco, Easton, USA) programmed for excitation at $290 \mathrm{~nm}$ and emission at $330 \mathrm{~nm}$, using the IS (tocol, Matreya, Pleasant Gap, PA, USA) method for quantification. Mobile phase consisted of a mixture of hexane:ethyl acetate (70:30, v/v, hexane and ethyl acetate HPLC-grade, Lab-Scan, Lisbon, Portugal), and chromatographic separation was performed using a Polyamide II column $(250 \times 4.6 \mathrm{~mm}$, $5 \mu \mathrm{m}$; YMC, Kyoto, Japan). The results (Clarity 2.4 software, DataApex, Prague, Czech Republic) were expressed in $\mathrm{g}$ per $100 \mathrm{~g}$ of dw.

\subsection{Extract preparation}

Extracts were prepared by maceration with a stirring agitation at $150 \mathrm{rpm}$, using methanol:water $(80: 20, \mathrm{v} / \mathrm{v}, 30 \mathrm{ml})$ at $25^{\circ} \mathrm{C}$ for $1 \mathrm{~h}$, then, the samples were filtered (Whatman No. 4 paper), as previously described by Barroso et al. (2016). The residue was further re-extracted with an additional $30 \mathrm{ml}$ portion of the methanol:water $(80: 20, \mathrm{v} / \mathrm{v}$, $30 \mathrm{ml}$ ) mixture. The combined extracts were evaporated (Büchi R-210, Flawil, Switzerland) to remove the methanol, and the aqueous phase was lyophilized.

\subsection{Phenolic compounds}

The extracts were re-dissolved in methanol/water $(80: 20$, v/v, $5 \mathrm{mg} / \mathrm{ml}$ ) and filtered through a $0.22-\mu \mathrm{m}$ disposable LC filter disk for HPLC-DAD-ESI/Mn analysis. The chromatographic analysis was carried out in a Dionex Ultimate 3000 UPLC (Thermo Scientific, San Jose, CA, USA) system equipped with a diode array detector coupled to a mass spectrometer detector (LC-DAD-ESI/MSn) and an Xcalibur ${ }^{\circledast}$ data system. The extracts were filtered through a $0.22-\mu \mathrm{m}$ disposable LC filter disk before injection. The chromatographic separation was performed as previously described by Bessada, Barreira, Barros, Ferreira, and Oliveira (2016), using 280 and $370 \mathrm{~nm}$ as preferred wavelengths for UV detection. Mass spectrometry detection was performed in negative mode, using a Linear Ion Trap LTQ XL mass spectrometer (ThermoFinnigan, San Jose, CA, USA) equipped with an ESI source. Phenolic compounds were identified using the previous identifications made in our laboratory (Barroso et al., 2016). For quantitative analysis, a calibration curve for each available phenolic standard (Extrasynthèse, Genay, France) was constructed based on the area of the peaks recorded at $330 \mathrm{~nm}$ (hydroxycinnamoyl derivatives) or $370 \mathrm{~nm}$ (flavonols) and results were expressed in $\mathrm{mg} / \mathrm{g}$ of extract.

\subsection{Evaluation of in vitro antioxidant properties}

The extracts were re-dissolved in methanol/water $(80: 20, \mathrm{v} / \mathrm{v})$ at a final concentration of $5 \mathrm{mg} / \mathrm{ml}$ and further diluted at different concentrations to perform the distinct in vitro assays. The antioxidant potential was evaluated by the DPPH (2,2-diphenyl-1-picrylhydrazyl, Alfa Aesar, Ward Hill, MA, USA) radical-scavenging activity and reducing power (measured by ferricyanide Prussian blue assay), following a procedure previously described by Barroso et al. (2016). The results were expressed as the extract concentrations providing $50 \%$ of antioxidant activity or 0.5 of absorbance $\left(\mathrm{EC}_{50}\right)$, calculated from the graphs of antioxidant activity percentages (DPPH assay) or absorbance at $690 \mathrm{~nm}$ (reducing power assay) against extract concentrations. Trolox was used as a standard (Sigma-Aldrich, St. Louis, MO, USA).

\subsection{Statistical analysis}

The experimental data were checked for normality (Shapiro-Wilk test) and homogeneity of variances (Levene's test) assumptions. When it was not possible to apply an analysis of variance (ANOVA) and for data that did not follow a normal distribution, non-parametric tests were performed to evaluate significant differences at a level of 5\%, using the EXCEL software, Microsoft Office Professional Plus 2010, version 14.0.7159.5000, with the add-in Analysis ToolPak (Microsoft Corp., USA). For each factor, $\mathrm{N}$ or Process, the results were grouped regardless of process (frozen fresh or dried) and regardless each $\mathrm{N}$ content, respectively. For N, the results are presented as the mean value regardless of the process (frozen fresh or dried). For the Process, the results are presented as the mean value regardless of $\mathrm{N}$ content. The standard deviations presented in the tables should not be regarded as a measure of accuracy of the methodologies, since they include the results for one of the factors (Process or N). Furthermore, a Pearson's correlation analysis between the antioxidant activity and all the analysed 
compounds was carried out, with a 95\% confidence level, using IBM SPSS Statistics software, version 23.0. (IBM Corp., Armonk, New York, USA).

\section{Results and discussion}

\subsection{Free sugars and tocopherols composition}

Tables 1 and 2 show the results obtained for free sugars and tocopherols, respectively, in stevia frozen fresh and dried leaves. Concerning free sugar composition (Table 1), seven different compounds were identified in all the studied samples, namely rhamnose, xylose, arabinose + fructose, glucose, sucrose, trehalose and raffinose. The most abundant sugars were xylose, arabinose + fructose and sucrose. The total sugar content in the studied samples decreased with the level of $\mathrm{N}$ fertilization, N0 presented the highest content and N3 $\left(100 \mathrm{~kg} \mathrm{Nha}^{-1}\right)$ the lowest one. This is in agreement with the observations made by Ibrahim et al. (2011) regarding the effects of $\mathrm{N}$ fertilization on primary and secondary metabolites of three varieties of Labisia pumila Blume. Nevertheless, $\mathrm{N} 1\left(25 \mathrm{~kg} \mathrm{Nha}^{-1}\right)$ presented similar and not significantly different sugar contents as those of N0, so it could be considered a good compromise $\mathrm{N}$ level for fertilization.

Concerning the process conditions, dried samples presented statistically higher contents in sugars than frozen fresh samples, $13.54 \pm 0.53$ vs. $12.11 \pm 2.04 \mathrm{~g} / 100 \mathrm{~g}$, except for xylose.

Regarding tocopherol composition (Table 2), frozen fresh $S$. rebaudiana leaves revealed a significantly higher content than the dried samples. Thermal sensitivity of tocopherols to relatively high temperatures may explain the obtained results, leading to a consequent reduction of the tocopherol content. Actually, the same results were already obtained by the authors in a previous study on frozen fresh $(12.70 \pm 0.10 \mathrm{~g} / 100 \mathrm{~g})$ and oven-dried $(6.16 \pm 0.02 \mathrm{~g} / 100 \mathrm{~g})$ samples of $S$. rebaudiana leaves (Barroso et al., 2016). On the other hand, a direct correlation between the different $\mathrm{N}$ rates used for fertilization and tocopherol contents was not observed. Nevertheless, although the differences were not statistically significant, the highest concentrations of total tocopherols were found in the samples with higher levels of $\mathrm{N}$ fertilization (N2 and N3 samples). In general, comparing the obtained results for the composition of free sugars and tocopherols, it is possible to infer that the drying process exerts a higher impact on the levels of those components than $\mathrm{N}$ fertilization.

\subsection{Phenolic composition}

Table 3 presents the obtained results for the phenolic composition in stevia leaves. Eighteen phenolic compounds were detected, including ten flavonoids (namely quercetin and kaempferol glycosides) and eight hydroxycinnamoyl derivatives. All the identified phenolic compounds were previously described by Barroso et al. (2016) in stevia leaves. Caffeic acid derivatives were the most abundant phenolic compounds in all the tested samples, namely 5-O-caffeoylquinic and 3,5-O-dicaffeoylquinic acids (compounds 3 and 11). In relation to flavonoids, quercetin glycosides were more abundant than kaempferol glycosides, with quercetin-3-O-rhamnoside (14) and quercetin-3-O-glucoside (7) was the majority derivative.

Dried samples presented higher levels of phenolic compounds than frozen fresh ones (126.65 vs $85.17 \mathrm{mg} / \mathrm{g}$ extract), even though quercetin-3-O-rutinoside and quercetin-O-pentosyl-deoxyhexoside (compounds 6 and $\mathbf{9}$, respectively) were not detected in the dried samples. Moreover, kaempferol- $O$-hexoside (12) was not detected in the frozen fresh samples, and no statistically significant differences were found for compounds 10, 14 and 18 between frozen fresh and dry samples. The obtained results are in line with those previously reported (Barroso et al., 2016), where half the concentration of phenolic compounds was found in frozen fresh samples than in oven-dried samples of $S$. rebaudiana leaves.

N1 samples (fertilized with $25 \mathrm{~kg} \mathrm{Nha}^{-1}$ ) showed significantly higher contents of total phenolic compounds than the other compounds, as well as some individual molecules (i.e., compounds 7-9 and 11-18), compared to non-fertilized samples. This aspect may be directly correlated with sugar content (Table 1 ). In fact, samples with the highest abundance in phenolic compounds were also those that presented the highest levels of free sugars (i.e. dried processed samples, and N1 and control N0 samples). Similar findings were reported by

Table 1

Sugar content (g/100 g dry weight) in Stevia rebaudiana Bertoni leaves, under different N substrate rates and process (frozen fresh and dried).

\begin{tabular}{|c|c|c|c|c|c|c|c|c|c|}
\hline & & Rhamnose & Xylose & Arab. + Fruct. & Glucose & Sucrose & Trehalose & Raffinose & Total \\
\hline \multirow[t]{4}{*}{ Nitrogen } & No & $0.52 \pm 0.03 \mathrm{ab}$ & $6.79 \pm 3.11 \mathrm{ab}$ & $2.67 \pm 0.67 c$ & $0.15 \pm 0.12 \mathrm{a}$ & $3.02 \pm 1.30 \mathrm{ab}$ & $0.42 \pm 0.05 \mathrm{a}$ & $0.53 \pm 0.36 \mathrm{a}$ & $14.10 \pm 1.01 \mathrm{a}$ \\
\hline & N1 & $0.45 \pm 0.09 \mathrm{bc}$ & $4.52 \pm 0.50 \mathrm{a}$ & $4.10 \pm 0.24 \mathrm{a}$ & $0.05 \pm 0.04 \mathrm{~b}$ & $3.32 \pm 0.32 \mathrm{a}$ & $0.34 \pm 0.18 \mathrm{~b}$ & $0.60 \pm 0.51 \mathrm{a}$ & $13.39 \pm 0.78 \mathrm{ab}$ \\
\hline & N2 & $0.41 \pm 0.02 \mathrm{c}$ & $4.55 \pm 0.34 \mathrm{a}$ & $3.51 \pm 0.35 b$ & $0.06 \pm 0.03 \mathrm{~b}$ & $2.85 \pm 0.81 \mathrm{ab}$ & $0.26 \pm 0.06 \mathrm{c}$ & $0.63 \pm 0.46 \mathrm{a}$ & $12.26 \pm 1.92 \mathrm{bc}$ \\
\hline & N3 & $0.54 \pm 0.03 \mathrm{a}$ & $3.71 \pm 0.38 b$ & $3.83 \pm 0.41 \mathrm{a}$ & $0.04 \pm 0.04 \mathrm{~b}$ & $2.48 \pm 0.78 \mathrm{~b}$ & $0.27 \pm 0.05 b c$ & $0.59 \pm 0.37 \mathrm{a}$ & $11.46 \pm 1.79 \mathrm{c}$ \\
\hline \multirow[t]{2}{*}{ Process } & Frozen fresh & $0.46 \pm 0.08 \mathrm{~A}$ & $5.73 \pm 2.41 \mathrm{~A}$ & $3.17 \pm 0.73 \mathrm{~B}$ & $0.13 \pm 0.08 \mathrm{~A}$ & $2.17 \pm 0.55 \mathrm{~B}$ & $0.29 \pm 0.11 \mathrm{~A}$ & $0.15 \pm 0.03 \mathrm{~B}$ & $12.11 \pm 2.04 \mathrm{~B}$ \\
\hline & Dried & $0.50 \pm 0.07 \mathrm{~A}$ & $4.17 \pm 0.42 \mathrm{~B}$ & $3.88 \pm 0.40 \mathrm{~A}$ & $0.02 \pm 0.02 \mathrm{~B}$ & $3.64 \pm 0.42 \mathrm{~A}$ & $0.33 \pm 0.05 \mathrm{~A}$ & $0.99 \pm 0.11 \mathrm{~A}$ & $13.54 \pm 0.53 \mathrm{~A}$ \\
\hline
\end{tabular}

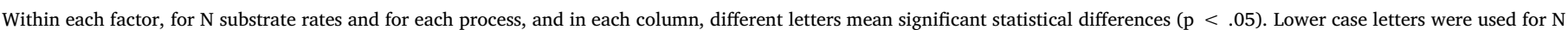
substrate rate parameters and capital letters were used for process.

Table 2

Tocopherol content (mg/100 g dry weight) in Stevia rebaudiana Bertoni leaves, under different N substrate rates and process (frozen fresh and dried).

\begin{tabular}{|c|c|c|c|c|c|}
\hline & & $\alpha$-tocopherol & $\gamma$-tocopherol & $\delta$-tocopherol & Total tocopherols \\
\hline \multirow[t]{4}{*}{ Nitrogen } & NO & $9.04 \pm 3.52 \mathrm{a}$ & $0.21 \pm 0.01 \mathrm{a}$ & $0.18 \pm 0.08 \mathrm{~b}$ & $9.42 \pm 3.59 \mathrm{a}$ \\
\hline & N1 & $8.50 \pm 2.67 \mathrm{a}$ & $0.17 \pm 0.08 \mathrm{a}$ & $0.25 \pm 0.07 \mathrm{ab}$ & $8.92 \pm 2.81 \mathrm{a}$ \\
\hline & N2 & $9.66 \pm 3.15 \mathrm{a}$ & $0.18 \pm 0.08 \mathrm{a}$ & $0.43 \pm 0.22 \mathrm{a}$ & $10.27 \pm 3.45 \mathrm{a}$ \\
\hline & N3 & $9.08 \pm 2.82 \mathrm{a}$ & $0.17 \pm 0.10 \mathrm{a}$ & $0.50 \pm 0.30 \mathrm{a}$ & $9.75 \pm 3.22 \mathrm{a}$ \\
\hline \multirow[t]{2}{*}{ Process } & Frozen fresh & $11.84 \pm 0.66 \mathrm{~A}$ & $0.24 \pm 0.03 \mathrm{~A}$ & $0.49 \pm 0.23 \mathrm{~A}$ & $12.57 \pm 0.74 \mathrm{~A}$ \\
\hline & Dried & $6.30 \pm 0.39 \mathrm{~B}$ & $0.13 \pm 0.06 \mathrm{~B}$ & $0.19 \pm 0.05 \mathrm{~B}$ & $6.61 \pm 0.40 \mathrm{~B}$ \\
\hline
\end{tabular}

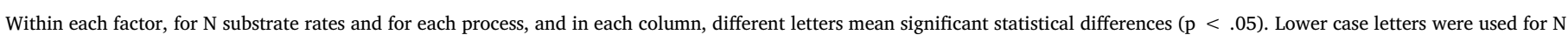
substrate rate parameters and capital letters were used for process 
Table 4

Antioxidant activity (expressed in $\mathrm{EC}_{50}$ values, $\mathrm{mg} / \mathrm{ml}$ ) of Stevia rebaudiana Bertoni leaves, under different $\mathrm{N}$ substrate rates and process (frozen fresh and dried).

\begin{tabular}{llll}
\hline & & DPPH scavenging activity & Reducing power \\
\hline Nitrogen & N0 & $36.76 \pm 14.59 \mathrm{ab}$ & $34.26 \pm 5.63 \mathrm{a}$ \\
& N1 & $40.82 \pm 10.45 \mathrm{a}$ & $31.21 \pm 1.63 \mathrm{~b}$ \\
& N2 & $30.06 \pm 4.33 \mathrm{~b}$ & $35.66 \pm 9.93 \mathrm{ab}$ \\
& N3 & $37.94 \pm 12.50 \mathrm{ab}$ & $32.14 \pm 6.43 \mathrm{ab}$ \\
Process & Frozen fresh & $46.40 \pm 7.57 \mathrm{~A}$ & $38.99 \pm 4.62 \mathrm{~A}$ \\
& Dried & $26.39 \pm 3.20 \mathrm{~B}$ & $27.64 \pm 1.83 \mathrm{~B}$ \\
\hline
\end{tabular}

Within each factor, for $\mathrm{N}$ substrate rates and for each process, and in each column different letters mean significant statistical differences $(p<.05)$. Lower case letters were used for $\mathrm{N}$ substrate rate parameters and capital letters were used for process.

Ibrahim et al. (2011), who suggested that high sugar content may exert a more pronounced influence on the synthesis and up regulation of secondary metabolites, and consequently increased total phenolic contents (in terms of both phenolic acids and flavonoids), as observed in the present study.

\subsection{Antioxidant activity}

Table 4 shows the results obtained in the assessment of the in vitro antioxidant potential of $S$. rebaudiana leaves, under different $\mathrm{N}$ substrate rates and process (fresh frozen and dried). Two different methods were used to determine the antioxidant activity of stevia samples, namely DPPH radical scavenging activity (RSA) and reducing power (RP). In general, dried samples revealed the best values $(\mathrm{RSA}=26.39 \pm 3.20 \mathrm{mg} / \mathrm{ml} ; \mathrm{RP}=27.64 \pm 1.83 \mathrm{mg} / \mathrm{ml})$. These results are also in agreement with those previously obtained (Barroso et al., 2016), in which oven-dried samples evidenced higher antioxidant capacity than frozen fresh samples.

$\mathrm{N} 2\left(\mathrm{EC}_{50}=30.06 \pm 4.33 \mathrm{mg} / \mathrm{ml}\right)$ and $\mathrm{N} 1\left(\mathrm{EC}_{50}=31.21 \pm 1.63 \mathrm{mg} /\right.$ $\mathrm{ml}$ ) samples presented the best results for RSA and RP, respectively, followed in each case by N0 and N3 samples. Thus, the measured antioxidant potential of stevia samples presented the following decreasing order: RSA: N2 $>$ N0 $>$ N3 > N1; RP: N1 > N3 > N0 > N2. A positive correlation was found when comparing the results obtained for the antioxidant activity with the phenolic compound content. Samples with greater abundance in phenolic compounds (i.e., N1 and dried processed samples) were those that revealed the highest antioxidant activity. On the other hand, and in a general manner, dried samples were at the same time those that presented the highest antioxidant potential, content of free sugars and phenolic compounds, and the lowest values of tocopherols. On the contrary, samples containing the highest content in tocopherols (frozen fresh samples) were those that presented the lowest antioxidant potential and phenolic compound content. These observations suggest that the antioxidant ability of stevia samples is more closely influenced by phenolic compounds than by tocopherols, which would not determine the antioxidant capacity and possible health-promoting potential of stevia leaves. Concerning samples obtained under different $\mathrm{N}$ substrate rates, significant composition differences were observed between the studied samples (mainly in terms of sugars and phenolic compounds). Moreover, better values of antioxidant activity were obtained for fertilized samples (i.e., N2 for RSA, and N1 and N3 for RP) than for the non-fertilized one NO. In this sense, it seems that N fertilization might provide a considerable improvement on the bioactive potential of stevia leaves.

Correlation factors were obtained between the antioxidant activity assays and phenolic compounds (individual compounds and total content), using a Pearson's correlation analysis, because the normality was verified through a Shapiro-Wilk test. The correlation of all the antioxidant assays (DPPH scavenging activity and reducing power) and phenolic compounds are presented in Table 5 . In general, the majority of the compounds showed correlations statistically significant with the antioxidant activity assays. Quercetin-3-O-rutinoside (compound 6) 
Table 5

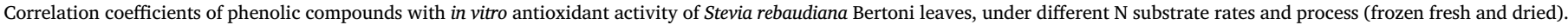

\begin{tabular}{|c|c|c|c|c|c|}
\hline \multirow[t]{2}{*}{ Peaks } & \multirow[t]{2}{*}{ Compounds } & \multicolumn{2}{|c|}{ DPPH scavenging activity } & \multicolumn{2}{|l|}{ Reducing power } \\
\hline & & Correlation factor & p-value & Correlation factor & p-value \\
\hline 1 & 3-O-Caffeoylquinic acid & -0.716 & $<.001$ & -0.688 & $<.001$ \\
\hline 2 & 4-O-Caffeoylquinic acid & -0.834 & $<.001$ & -0.759 & $<.001$ \\
\hline 3 & 5-O-Caffeoylquinic acid & -0.860 & $<.001$ & -0.815 & $<.001$ \\
\hline 4 & Caffeoyl-2,7-anhydro-3-deoxy-2-octulopyranosonic acid & -0.807 & $<.001$ & -0.746 & $<.001$ \\
\hline 5 & Caffeic acid derivative & -0.891 & $<.001$ & -0.840 & $<.001$ \\
\hline 6 & Quercetin-3-O-rutinoside & 0.989 & $<.001$ & 0.944 & $<.001$ \\
\hline 7 & Quercetin-3-O-glucoside & -0.606 & .002 & -0.617 & .001 \\
\hline 8 & 3,4-O-Dicaffeoylquinic acid & -0.894 & $<.001$ & -0.853 & $<.001$ \\
\hline 9 & Quercetin-O-pentosyl-deoxyhexoside & -0.872 & .008 & -0.806 & .002 \\
\hline 10 & Kaempferol-3-O-glucoside & 0.538 & .021 & 0.526 & .025 \\
\hline 11 & 3,5-O-Dicaffeoylquinic acid & -0.794 & $<.001$ & 0.740 & $<.001$ \\
\hline 12 & Kaempferol-O-hexoside & 0.891 & $<.001$ & 0.852 & $<0.001$ \\
\hline 13 & Quercetin-3-O-xyloside & -0.719 & .008 & -0.616 & .033 \\
\hline 14 & Quercetin-3-O-rhamnoside & -0.189 & .377 & -0.194 & .364 \\
\hline 15 & 4,5-O-Dicaffeoylquinic acid & -0.809 & $<.001$ & -0.794 & $<.001$ \\
\hline 16 & Kaempferol-O-pentoside & 0.921 & $<.001$ & 0.713 & $<.001$ \\
\hline 17 & Kaempferol-O-pentoside & -0.078 & .759 & -0.176 & .486 \\
\hline \multirow[t]{4}{*}{18} & Kaempferol-O-deoxyhexoside & 0.143 & .572 & 0.217 & .388 \\
\hline & Total phenolic acids & -0.925 & $<.001$ & -0.872 & $<.001$ \\
\hline & Total flavonoids & -0.694 & .017 & -0.690 & .019 \\
\hline & Total phenolic compounds & -0.807 & $<.001$ & -0.768 & $<.001$ \\
\hline
\end{tabular}

presented the most significant correlation with all antioxidant activities tested. Nonetheless, the total flavonoid content was less strongly correlated with the antioxidant activity in comparison with the total phenolic acids, which could be due to its higher concentration present in the samples. The total phenolic compounds also presented an excellent correlation factor. With the exception of quercetin-3-O-rhamnoside, kaempferol-O-pentoside and kaempferol-O-deoxyhexoside (compounds 14, 17 and 18), which were the only compounds that did not present a statistically significant correlation with the antioxidant assays, presenting $p$-value $>.05$, all the remaining compounds presented good correlation factors. The major individual phenolic compound (5-O-caffeoylquinic acid) also had a high correlation with the antioxidant activity assays, showing a variation between -0.860 and -0.815 . Overall, total phenolic acids and total phenolic compounds showed statistically significant correlations with both the assays, displaying $p$-values $\leq .05$.

\section{Conclusion}

Considering all the obtained results, it is possible to conclude that the drying process exerts a higher impact on the chemical content than $\mathrm{N}$ fertilization. Dried samples were those that presented statistically higher contents in free sugars and phenolic compounds than frozen fresh samples, while frozen fresh samples revealed a higher content of tocopherols. Moreover, stevia samples with the highest abundance in phenolic compounds and free sugars (i.e. dried processed samples, and $\mathrm{N} 1$ and control N0 samples), with the lowest levels of tocopherols, were also those that revealed the highest antioxidant potential. Therefore, it seems that the antioxidant activity of stevia leaves is more closely determined by phenolic compounds content than tocopherols. Furthermore, correlation factors were determined between the antioxidant activity and the phenolic compounds, which revealed a high correlation with most of the individual compounds, along with the total phenolic acids and total phenolic compounds. Thus, the present findings regarding cultivation practices and how they can affect the quality and chemical composition of stevia leaves, may provide considerable insights for their upcoming use for health-promoting purposes.

\section{Acknowledgements}

The authors are grateful to the Foundation for Science and Technology (FCT, Portugal) and FEDER under Programme PT2020 for financial support to CIMO (UID/AGR/00690/2013) and to L. Barros contract. The authors are also grateful to the Interreg España-Portugal for financial support through the project 0377_Iberphenol_6_E. The GIPUSAL is financially supported by the Spanish Government through the project AGL2015-64522-C2-2-R.

\section{References}

Aires, A., Rosa, E., \& Carvalho, R. (2006). Effect of nitrogen and sulfur fertilization on glucosinolates in the leaves and roots of broccoli sprouts (Brassica oleracea var. italica). Journal of the Science of Food and Agriculture, 86, 1512-1516. http://dx.doi. org/10.1002/jsfa.2535.

Álvarez-Robles, M. J., López-Orenes, A., Ferrer, M. A., \& Calderón, A. A. (2016). Methanol elicits the accumulation of bioactive steviol glycosides and phenolics in Stevia rebaudiana shoot cultures. Industrial Crops and Products, 87, 273-279. http://dx.doi. org/10.1016/j.indcrop.2016.04.054.

Barroso, M., Barros, L., Rodrigues, M.Â., Sousa, M. J., Santos-Buelga, C., \& Ferreira, I. C. F. R. (2016). Stevia rebaudiana Bertoni cultivated in Portugal : A prospective study of its antioxidant potential in different conservation conditions. Industrial Crops and Products, 90, 49-55. http://dx.doi.org/10.1016/j.indcrop.2016.06.013.

Bessada, S. M., Barreira, J. C. M., Barros, L., Ferreira, I. C. F. R., \& Oliveira, M. B. P. P. (2016). Phenolic profile and antioxidant activity of Coleostephus myconis (L.) Rchb. f.: An underexploited and highly disseminated species. Industrial Crops and Products, $89,45-51$.

Brandle, J., \& Rosa, N. (1992). Heritabilrty for yield, leaf: Stem ratio and stevioside content estimated from a landrace cultivar of Stevia rebaudiana. Canadian Journal of Plant Science, 72, 1263-1266.

Brandle, J. E., Starratt, A. N., \& Gijzen, M. (1998). Stevia rebaudiana: Its agricultural, biological, and chemical properties. Canadian Journal of Plant Science, 78(4), 527-536. http://dx.doi.org/10.4141/P97-114.

Gardana, C., Scaglianti, M., \& Simonetti, P. (2010). Evaluation of steviol and its glycosides in Stevia rebaudiana leaves and commercial sweetener by ultra-high-performance liquid chromatography-mass spectrometry. Journal of Chromatography A, 1217(9), 1463-1470. http://dx.doi.org/10.1016/j.chroma.2009.12.036.

Goyal, S. K., Samsher, \& Samsher, R. K. (2010). Stevia (Stevia rebaudiana) a bio-sweetener: A review. International Journal of Food Sciences and Nutrition, 61(1), 1-10. http://dx. doi.org/10.3109/09637480903193049.

Gupta, E., Purwar, S., Sundaram, S., \& Rai, G. K. (2013). Nutritional and therapeutic values of Stevia rebaudiana: A review. Journal of Medicinal Plant Research, 7(46), 3343-3353. http://dx.doi.org/10.5897/JMPR2013.5276.

Ibrahim, M. H., Jaafar, H. Z. E., Rahmat, A., \& Rahman, Z. A. (2011). Effects of nitrogen fertilization on synthesis of primary and secondary metabolites in three varieties of kacip fatimah (Labisia pumila Blume). International Journal of Molecular Sciences, 
12(8), 5238-5254. http://dx.doi.org/10.3390/ijms12085238.

Karimi, E., Jaafar, H. Z. E., \& Ahmad, S. (2013). Antifungal, anti-inflammatory and cytotoxicity activities of three varieties of Labisia pumila Benth: From microwave obtained extracts. BMC Complementary and Alternative Medicine, 13(20), 1-10.

Koeduka, T., Fridman, E., Gang, D. R., Vassão, D. G., Jackson, B. L., Kish, C. M., ... Pichersky, E. (2006). Eugenol and isoeugenol, characteristic aromatic constituents of spices, are biosynthesized via reduction of a coniferyl alcohol ester. Proceedings of the National Academy of Sciences of the United States of America, 103(26), 10128-10133. http://dx.doi.org/10.1073/pnas.0603732103.

Rajasekaran, T., Ramakrishna, A., Sankar, K. U., Giridhar, P., \& Ravishankar, G. A. (2008). Analysis of predominant steviosides in Stevia rebaudiana Bertoni by liquid chromatography/electrospray ionization-mass spectrometry. Food Biotechnology, 22(2), 179-188. http://dx.doi.org/10.1080/08905430802043255.

Rodrigues, M. A., Afonso, S., Ferreira, I. Q., \& Arrobas, M. (2016). Response of stevia to nitrogen fertilization and harvesting regime in northeastern Portugal. Archives of Agronomy and Soil Science, 1-12. http://dx.doi.org/10.1080/03650340.2016.
1230272.

Tadhani, M. B., Patel, V. H., \& Subhash, R. (2007). In vitro antioxidant activities of Stevia rebaudiana leaves and callus. Journal of Food Composition and Analysis, 20(3-4), 323-329. http://dx.doi.org/10.1016/j.jfca.2006.08.004.

Tavarini, S., Sgherri, C., Ranieri, A. M., \& Angelini, L. G. (2015). Effect of nitrogen fertilization and harvest time on steviol glycosides, flavonoid composition, and antioxidant properties in Stevia rebaudiana Bertoni. Journal of Agricultural and Food Chemistry, 63(31), 7041-7050. http://dx.doi.org/10.1021/acs.jafc.5b02147.

Yadav, A. K., Singh, S., Dhyani, D., \& Ahuja, P. S. (2011). A review on the improvement of stevia [Stevia rebaudiana (Bertoni)]. Canadian Journal of Plant Science, 91(1), 1-27. http://dx.doi.org/10.4141/cjps10086.

Yildiz-Ozturk, E., Nalbantsoy, A., Tag, O., \& Yesil-Celiktas, O. (2015). A comparative study on extraction processes of Stevia rebaudiana leaves with emphasis on antioxidant, cytotoxic and nitric oxide inhibition activities. Industrial Crops and Products, 77, 961-971. http://dx.doi.org/10.1016/j.indcrop.2015.10.010. 


\title{
Stevia rebaudiana Bertoni obtained by in vitro culture with kinetin: focus on chemical composition and antioxidant compounds
}

\author{
Marisa R. Barroso, ${ }^{1,2}$ Natália Martins, ${ }^{1,3}$, Lillian Barros, ${ }^{1}$ M. Beatriz P.P. Oliveira ${ }^{3}$, M. Ângelo \\ Rodrigues, ${ }^{1}$ Maria João Sousa, ${ }^{1}$ Celestino Santos-Buelga, ${ }^{2}$ Isabel C.F.R. Ferreira ${ }^{1,}$
}

${ }^{1}$ Centro de Investigação de Montanha (CIMO), Instituto Politécnico de Bragança, Campus de Santa Apolónia, 5300-253 Bragança, Portugal

${ }^{2}$ Grupo de Investigación en Polifenoles (GIP-USAL), Facultad de Farmacia, Universidad de Salamanca, Campus Miguel de Unamuno s/n, 37007 Salamanca, España

${ }^{3}$ REQUIMTE/LAQV, Faculdade de Farmácia, Universidade do Porto, Rua Jorge Viterbo Ferreira, $\mathrm{n}^{\circ} 228,4050-313$ Porto, Portugal

* Correspondence: iferreira@ipb.pt (I.C.F.R.F.); Tel.: +351-273-303-219

Received: date; Accepted: date; Published: date

\begin{abstract}
Plant growth regulators are used in the development of in vitro plant cultures, controlling the physiological processes in specialized cells. In this study, Stevia rebaudiana Bertoni leaves obtained by in vitro culture with and without kinetin (phytoregulator) were analyzed to compare their composition in some free sugars, tocopherols and phenolic compounds, as also to assess the antioxidant activity of their methanol: water extracts. Samples cultured without kinetin evidenced higher concentration in total tocopherols and phenolic compounds, than those obtained in the presence of kinetin. Otherwise, an opposite trend was observed for total free sugars. Methanol: water extracts obtained from samples cultured without kinetin also evidenced higher radical scavenging activity (EC50: $191 \pm 6 \mu \mathrm{g} / \mathrm{mL}$ ) and reducing power $(70.1 \pm 0.7 \mu \mathrm{g} / \mathrm{mL})$ than those cultured in the presence of kinetin; which seems related with the concentration of phenolic compounds. Overall, in vitro culture can be used as an efficient way to produce plant sources of antioxidant compounds, but other hormones besides kinetin have to be tested to improve bioactive molecules production
\end{abstract}

Keywords: Tissue culture; Plant growth regulator; Cytokinin analog; Stevia; Tocopherols; Free sugars; Phenolic compounds

\section{Introduction}

World Health Organization (WHO) estimates that $80 \%$ of world population still depends on traditional medicines to obtain primarily basic health care. Indeed, two thirds of the existing anti-carcinogenic and anti-infectious drugs in the market derives from plants. In addition, with the unceasing market demand for natural products, an environmental concern emerges relatively to the loss of plant populations, genetic diversity, habitat degradation and, even, species extinction [1].

Plant tissue culture is an alternative beyond the whole plant cultivation to produce secondary metabolites that are used as pharmaceuticals, flavors, fragrances, coloring agents, food additives, and agrochemicals [2]. In fact, the search for plant growth regulators, also known phytohormones, has revolutionized the development of in vitro plants culture, by allowing to control physiological 
processes of more specialized cells, and even through inducing secondary metabolites production [1]. Cytokinins are a group of phytohormones that stimulate water uptake, increase cell division, promote organ development and even lead to shoots regeneration and proliferation. Kinetin (6-furfurylaminopurin) is an example of a synthetic cytokinin that has evidence of being able to mitigate the adverse effects of salt stress during plant growth [3].

Stevia rebaudiana Bertoni, a perennial shrub belonging to the Asteraceae family, is a sweet herb native from certain regions of South America (Paraguay and Brazil), but nowadays globally consumed. It is also cultivated in China, Korea, Mexico, United States, Southeast Asia and Europe, including in the north-eastern of Portugal $[4,5]$. A non-caloric natural sweetener produced from its leaf extract is widely used in soft drinks, soy sauce, instant noodles, yogurt and other foods in many countries [5]. The in vitro antioxidant and preventive activity against DNA oxidative damage have been reported for crude methanol, ethyl acetate [6] and methanol: water [4] extracts obtained from $S$. rebaudiana leaves. The latter study focused on the impact of cultivation conditions on its chemical composition [4]. In fact, well-established cultivation conditions have revealed to be determinant for both plant production and bioactive compounds concentration, acting as conditioners of the biological activity. On the other hand, conservation conditions have also been pointed out as having a direct effect on both bioactive constituents concentration and, consequently, on stevia biological activity [4]. In this sense, considering that both cultivation and conservation conditions seem to exert a crucial role on S. rebaudiana biological activity, in the present work, leaves obtained by in vitro culture were analyzed in terms of antioxidants. More specifically, samples obtained in the presence of kinetin were compared with samples cultured without this phytohormone, in terms of tocopherols, free sugars and phenolic compounds, and lastly antioxidant effects.

\section{Results}

\subsection{In vitro culture of $S$. rebaudiana leaves}

The percentage of explant survival after sterilization was $95 \%$, which means that plant material grown in the medium containing kinetin multiplies at large extent (Figure 1). Also, the multiplication rate was much higher in the in vitro culture with kinetin, being $3 x$ higher than the in vitro culture without kinetin.

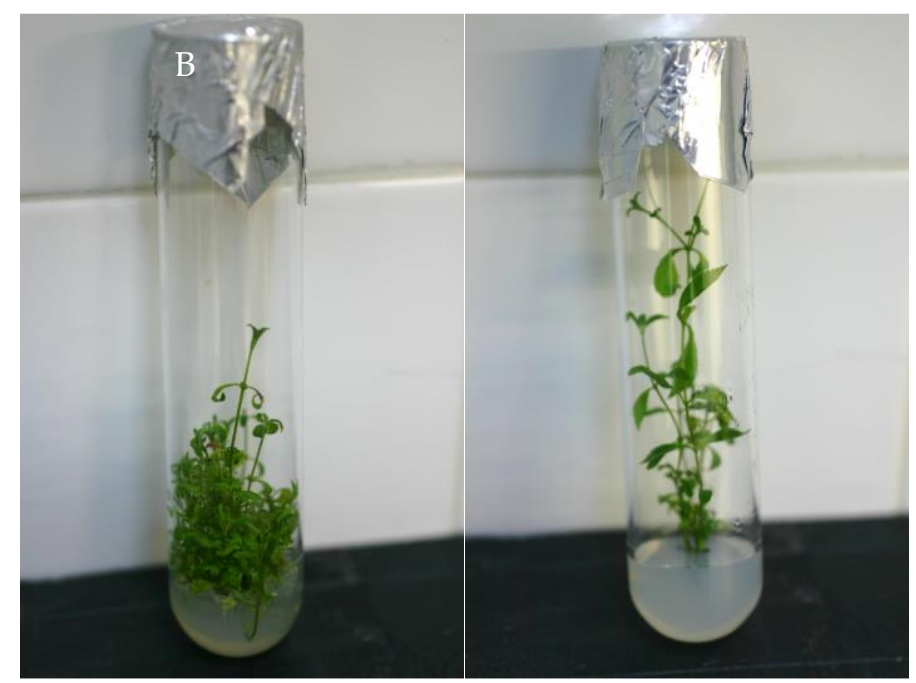

Figure 1. In vitro cultured S. rebaudiana leaves with kinetin (A) and without kinetin (B).

In the medium containing kinetin, from an initial single explant, 12-14 new shoots were reached, while in the medium without kinetin only 3 to 4 were observed. Based on this data, 
medium containing kinetin presented a larger multiplication rate, despite presenting a lower height growth. On the other hand, in the medium without kinetin, fewer new shoots were counted, although they were more developed in height in relation to the pre-existing ones. In fact, being acytokinins a phytoregulator responsible for cell multiplication, the present findings would be expected. Others reports already suggest that cytokinins play an important role while regulatory factors of plant meristem activity and morphogenesis, since they act in vital molecular processes of all plants [7]. In fact, the development of in vitro root systems occurs spontaneously, also allowing to obtain complete plants in a vegetative state. Moreover, through increasing cell division, it will be possible to obtain a greater number of plants for subsequent tests, and at the same time favor a greater morphological and physiological similarity with ex vitro counterparts.

\subsection{Free sugars and tocopherols}

Table 1 shows the obtained results for S. rebaudiana leaves in vitro cultured regarding contents of tocopherols and free sugars. Samples cultured without kinetin presented higher abundance in $\alpha$-tocopherol, $\gamma$-tocopherol, $\delta$-tocopherol, and total tocopherols than those cultured in the presence of kinetin (Figure 2A). The same tocopherol profile was found by the authors in cultivated $S$. rebaudiana leaves using different conservation conditions [4], thus to the best of our knowledge, there are no reports regarding kinetin influence on the tocopherol composition in stevia. Tounekti et al. [8] performed an experiment aiming at determining the effect of kinetin on antioxidant compounds (including tocopherols) in Stevia officinalis. The authors observed an increase in tocopherols content over time using kinetin, but only under stress conditions; no significant differences were observed in samples that were not cultured under those conditions [8]. These higher contents could be explained by the increase of transcript levels of isoprenoid and tocopherol biosynthetic genes, namely DXPRI, VTE2 and VTE4 in control plants, which encode, respectively, 1-deoxy-D-xylulose 5-phosphate reductoisomerase, homogentisate phytyltransferase and $\alpha$-tocopherol methyltransferase enzymes [8]. The fact that no significant increase was observed in tocopherols levels could be attributed to the kinetin concentration used $(0.5 \mathrm{mg} / \mathrm{L})$. For instance, Tounekti et al. [8] using a concentration of $10 \mu \mathrm{M}$ of kinetin, only stated a slight increase in the final tocopherols content when compared to the control sample. On the other hand, in a study performed by Barroso et al. [9], the authors found that the final tocopherols content was affected not only by the process conditions, but also by nitrogen concentration used for medium supplementation. Thus, frozen fresh samples revealed a higher content in tocopherols than dried samples, while tocopherols varied according to nitrogen rates used, being the highest content in tocopherols observed in stevia samples fertilized with the higher nitrogen concentrations [9].

In relation to free sugars content, stevia samples cultured with kinetin evidenced a higher concentration in fructose, glucose, raffinose, and total free sugars than those grown without kinetin (Figure 2B). No significant differences were observed for trehalose $(\mathrm{p}=0.019)$ and sucrose $(\mathrm{p}=0.793)$. A similar sugar profile was found by the authors in cultivated S. rebaudiana leaves using different conservation conditions [4], thus not revealing xylose, ramnose, and arabinose. Ahmed and Khalid [10] evaluating the kinetin capacity to increase nutrients and other chemical constituents in Nigella sativa L., stated a close dependency with the kinetin concentration applied. The highest concentration of soluble sugars was obtained at $20 \mathrm{mg} / \mathrm{L}$ of kinetin, while no significant differences were observed at $10 \mathrm{mg} / \mathrm{L}$; however, from 30 to $40 \mathrm{mg} / \mathrm{L}$, sugars content decreased with the increase of kinetin concentration [10]. As far as we know, there are no reports regarding kinetin influence on sugar composition in stevia. Nevertheless, in a previous study performed by Barroso et al. [4], it was found that free sugars composition in stevia leaves is markedly affected by conservation conditions (i.e., the authors found a higher content of free sugars in frozen fresh samples than in oven-dried samples). 
Table 1. Composition in tocopherols and free sugars of $S$. rebaudiana leaves cultivated in vitro $(\mathrm{n}=9$, mean $\pm \mathrm{SD})$.

\begin{tabular}{cccc}
\hline Compounds & $\begin{array}{c}\text { In vitro culture } \\
\text { with kinetin }\end{array}$ & $\begin{array}{c}\text { In vitro culture } \\
\text { without kinetin }\end{array}$ & $\begin{array}{c}t \text {-Students test } \\
\boldsymbol{p} \text {-value }\end{array}$ \\
\hline$\alpha$-Tocopherol & $21.4 \pm 0.4$ & $27.77 \pm 0.04$ & $<0.001$ \\
$\gamma$-Tocopherol & $0.10 \pm 0.01$ & $0.18 \pm 0.01$ & $<0.001$ \\
$\delta$-Tocopherol & $1.6 \pm 0.1$ & $2.86 \pm 0.09$ & $<0.001$ \\
Total (mg/100 g dw) & $23.0 \pm 0.5$ & $30.8 \pm 0.1$ & $<0.001$ \\
\hline Fructose & $1.81 \pm 0.06$ & $1.2 \pm 0.1$ & 0.001 \\
Glucose & $1.90 \pm 0.08$ & $1.59 \pm 0.08$ & 0.002 \\
Sucrose & $3.1 \pm 0.3$ & $3.1 \pm 0.2$ & 0.793 \\
Trehalose & $0.68 \pm 0.02$ & $0.54 \pm 0.01$ & $<0.001$ \\
Raffinose & $0.43 \pm 0.05$ & $0.52 \pm 0.02$ & 0.019 \\
Total (g/100 g dw) & $8.0 \pm 0.6$ & $6.9 \pm 0.4$ & $<0.001$ \\
\hline
\end{tabular}

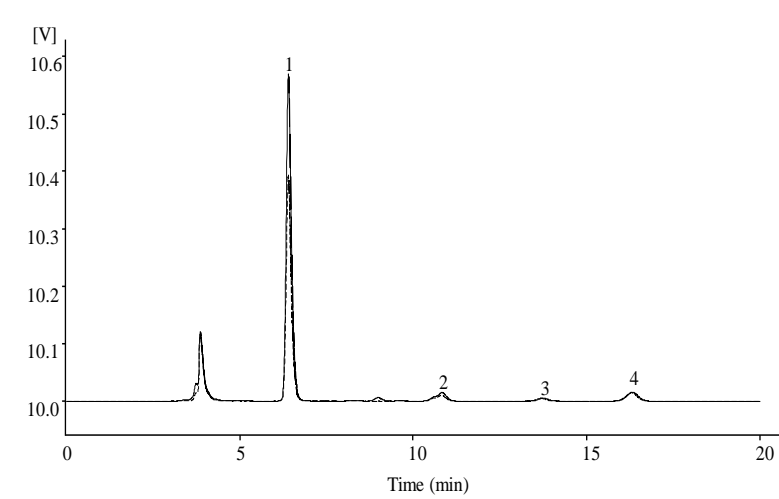

A

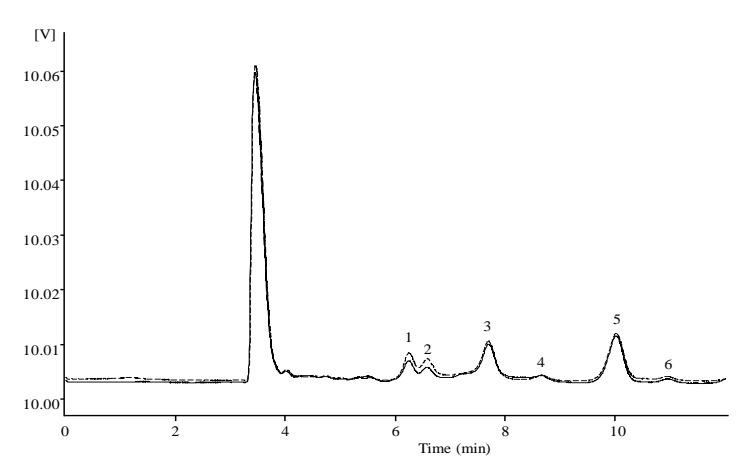

B

Figure 2. Tocopherols (A) and free sugars (B) profile from S. rebaudiana leaves in vitro cultivated without (-) and with kinetin (---) (A: 1- $\alpha$-tocopherol, 2- $\gamma$-tocopherol, 3- $\delta$-tocopherol, 4- Tocol (IS); and B: 1- fructose, 2- glucose, 3- sucrose, 4- treahalose, 5- melezitose (IS), 6- raffinose).

\subsection{Phenolic compounds}

Figure 3 and Table 2 shows the results obtained for phenolic compounds identification and individual quantification. Nine phenolic compounds were identified in the methanol: water extracts being all of them chlorogenic acids, namely 3-O-caffeoylquinic acid (1), 4-O-caffeoylquinic acid (2), 5-O-caffeoylquinic acid (3), cis 3,4-O-dicaffeoylquinic acid (4), trans 3,4-O-dicaffeoylquinic acid (5), cis 3,5-O-dicaffeoylquinic acid (6), trans 3,5-O-dicaffeoylquinic acid (7), cis 4,5-O-dicaffeoylquinic acid (8), and trans 4,5-O-dicaffeoylquinic acid (9). All these compounds were previously described by the authors in stevia samples obtained from cultivated plants [4]. Interestingly, in the previous studies cis forms of dicaffeoylquinic acid were not identified, being only present the trans forms. Hydroxycinnamoyl cis derivatives are expected to elute before the corresponding trans ones, as observed after hydroxycinnamic acids UV irradiation (366 nm, $24 \mathrm{~h}$ ), even though it would be expected to have higher quantities of trans than cis forms. 
Samples cultured with kinetin presented a lower concentration in total phenolic compounds and in compounds $3,5,6$, and 7 than those cultured without kinetin. Otherwise, compounds 1 and 2 were more abundant in samples cultured in the presence of kinetin, while no significant differences were observed for compounds 4, 8, and 9. Among the compounds analyzed in the present study, the final concentration increased in only two caffeoylquinic acids (1 and 2). For example, Radić et al. [11] studied the influence of two plant growth regulators (indole-3-acetic acid and indole-3-butyric acid) on secondary metabolites production (i.e., total phenolics and flavonoids content) in S. rebaudiana leaves. The authors found a positive effect from both plant growth regulators on those secondary metabolites production, being the improvement observed dependent of the concentration applied: the highest effect was stated using indole-3-butyric acid at $1.5 \mathrm{mg} / \mathrm{L}$. Beside these aspects, the authors also found that the final content in secondary metabolites was also highly affected by the medium $\mathrm{pH}$ levels, in which total phenolics and flavonoids tended to decrease with the increasing $\mathrm{pH}$ levels. Thus, by comparing our results with those of the previous cited authors, it is feasible to suppose that by modifying the culture conditions (i.e, $\mathrm{pH}$ levels) it would be possible to accurately infer the real kinetin benefits on the phenolic composition in stevia leaves.

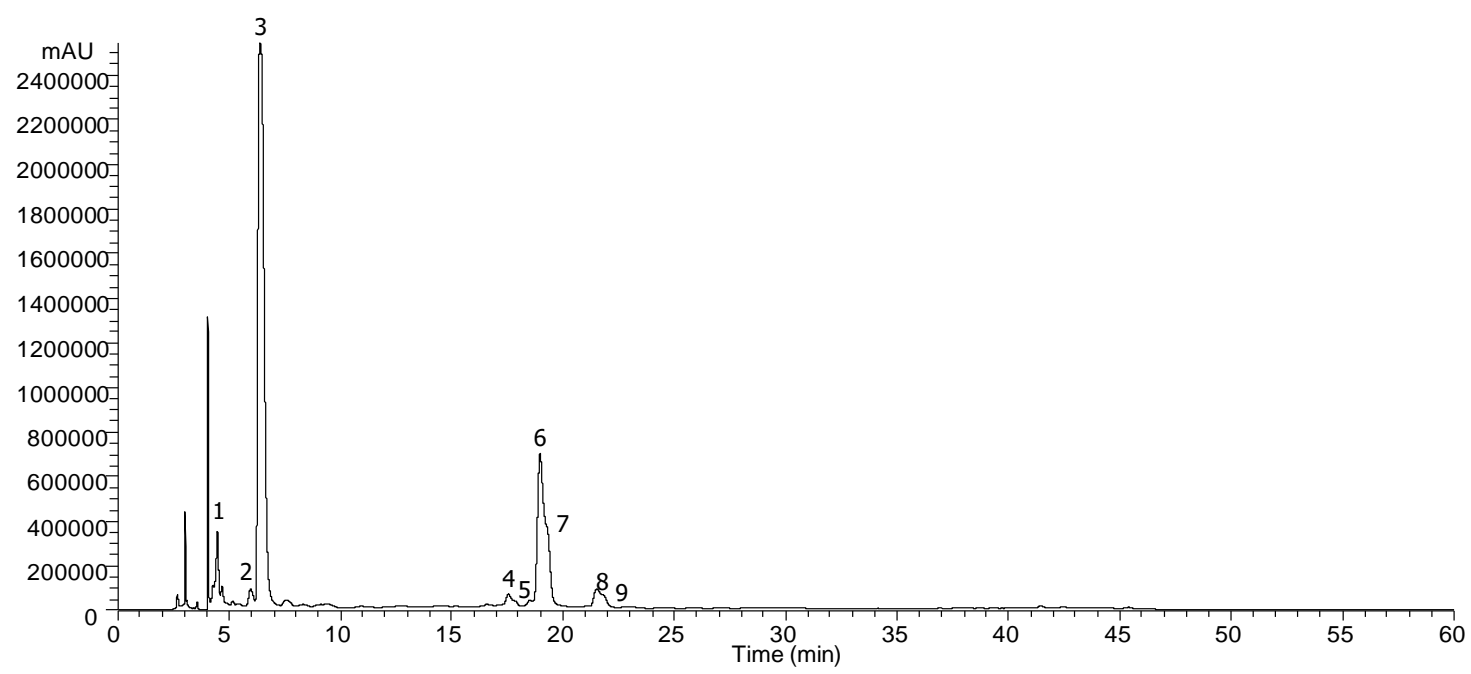

A

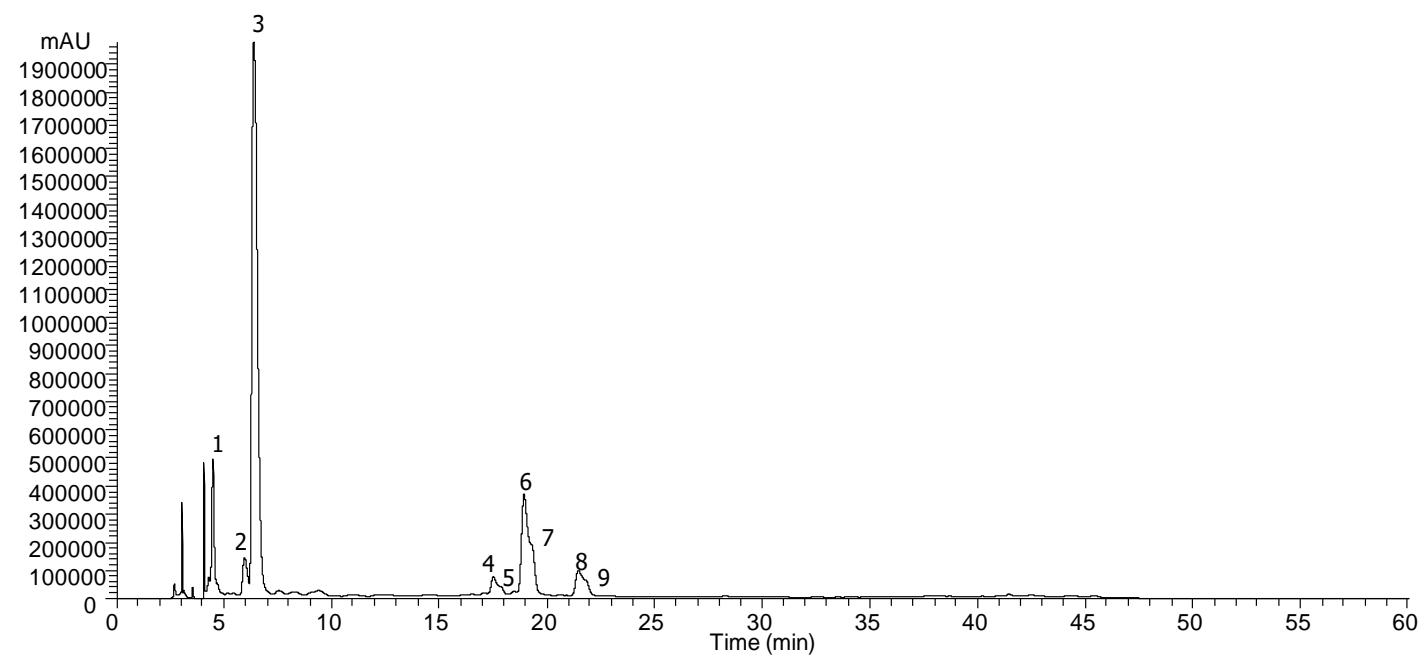

B

Figure 3. Phenolic profile of S. rebaudiana leaves cultivated in vitro without kinetin (A) and with kinetin (B), recorded at $330 \mathrm{~nm}$. 
Table 2. Phenolic compounds identification and quantification in S. rebaudiana leaves cultivated in vitro ( $\mathrm{n}=9$, mean $\pm \mathrm{SD})$.

\begin{tabular}{|c|c|c|c|c|c|c|c|c|}
\hline \multirow{2}{*}{$\begin{array}{l}\text { Compou } \\
\text { nds }\end{array}$} & \multirow{2}{*}{$\begin{array}{l}\text { Rt } \\
(\min )\end{array}$} & \multirow{2}{*}{$\begin{array}{l}()_{\max } \\
(\mathrm{nm})\end{array}$} & \multirow{2}{*}{$\begin{array}{l}\text { Pseudomolecular } \\
\text { ion } \\
{[\mathrm{M}-\mathrm{H}]^{-}(\mathrm{m} / \mathrm{z})}\end{array}$} & \multirow{2}{*}{$\begin{array}{l}\mathrm{MS}^{2} \\
(\mathrm{~m} / \mathrm{z})\end{array}$} & \multirow{2}{*}{ Tentative identification } & \multicolumn{2}{|c|}{ Quantification (mg/100 g dw) } & \multirow{2}{*}{$\begin{array}{l}t \text {-Students } \\
\text { - test } \\
p \text {-value }\end{array}$} \\
\hline & & & & & & $\begin{array}{l}\text { In vitro culture } \\
\text { with kinetin }\end{array}$ & $\begin{array}{l}\text { In vitro culture } \\
\text { without kinetin }\end{array}$ & \\
\hline 1 & 4.5 & 328 & 353 & 191(100),179(45),161(6),135(66) & 3-O-Caffeoylquinic acid & $112 \pm 3$ & $94.3 \pm 0.4$ & $<0.001$ \\
\hline 2 & 5.9 & 328 & 353 & 191(72),179(80),173(100),161(9),135(77) & 4-O-Caffeoylquinic acid & $62.3 \pm 0.3$ & $45.6 \pm 0.3$ & $<0.001$ \\
\hline 3 & 6.4 & 328 & 353 & 191(100),179(3),161(6),135(4) & 5-O-Caffeoylquinic acid & $795 \pm 2$ & $1385 \pm 1$ & $<0.001$ \\
\hline 4 & 17.5 & 328 & 515 & 353(87),335(45),191(41),179(76),173(91),161(17),135(25) & cis 3,4-O-Dicaffeoylquinic acid & $31.1 \pm 0.3$ & $31 \pm 2$ & 0.477 \\
\hline 5 & 17.8 & 328 & 515 & $353(87), 335(45), 191(41), 179(76), 173(91), 161(17), 135(25)$ & trans 3,4-O-Dicaffeoylquinic acid & $14.4 \pm 0.6$ & $9.7 \pm 0.5$ & $<0.001$ \\
\hline 6 & 18.9 & 328 & 515 & 353(90),335(8),191(100),179(89),173(14),161(8),135(46) & cis 3,5-O-Dicaffeoylquinic acid & $141 \pm 7$ & $270 \pm 15$ & $<0.001$ \\
\hline 7 & 19.3 & 328 & 515 & $353(90), 335(8), 191(100), 179(89), 173(14), 161(8), 135(46)$ & trans 3,5-O-Dicaffeoylquinic acid & $48 \pm 2$ & $121 \pm 1$ & $<0.001$ \\
\hline 8 & 21.5 & 328 & 515 & $353(81), 335(3), 191(21), 179(73), 173(100), 135(21)$ & cis 4,5-O-Dicaffeoylquinic acid & $34.47 \pm 0.04$ & $28 \pm 1$ & 0.001 \\
\hline \multirow[t]{2}{*}{9} & 21.8 & 328 & 515 & $353(81), 335(3), 191(21), 179(73), 173(100), 135(21)$ & trans 4,5-O-Dicaffeoylquinic acid & $18.2 \pm 0.5$ & $20.1 \pm 0.2$ & 0.001 \\
\hline & & & & & Total phenolic compounds & $1238 \pm 1$ & $1985 \pm 18$ & $<0.001$ \\
\hline
\end{tabular}




\subsection{Antioxidant activity}

The results of the antioxidant activity of the methanol: water extracts prepared from in vitro cultured stevia are shown in Table 3. Samples cultured without kinetin revealed higher radical scavenging activity and reducing power than those cultured in the presence of kinetin. Tounekti et al. [8], using leaf extracts from Salvia officinalis grown with kinetin under control and stress conditions, observed a significant improvement on the antioxidant activity only when kinetin was used under stress conditions. On the other hand, Radić et al. [11] performing an evaluation of $S$. rebaudiana antioxidant capacity, using different plant growth regulators (i.e., indole-3-acetic and indole-3-butyric acids), observing that the antioxidant activity of S. rebaudiana tissues (leaves, callus and roots) were significantly affected, in some cases, by the different plant hormones and medium $\mathrm{pH}$ values applied. The authors also observed that the antioxidant capacity evidenced by a specific plant growth regulator was affected by the concentration used (i.e., antioxidant activity increased through reducing indole-3-acetic acid concentration, and increased increasing indole-3-butyric acid) [11]. Khalil et al. [12] assessed the synergistic effects of polyamines and plant growth regulators on in vitro S. rebaudiana propagation, stevioside production and antioxidant capacity, and highlighted that the antioxidant capacity of in vitro cultures was positively regulated through combining polyamines and cytokinin rather than biomass accumulation. Thus, it would be interesting to assess other variables (e.g., different stress conditions) and plant growth regulators together with kinetin.

Table 3. Antioxidant activity ( $\mathrm{EC}_{50}$ values, $\left.\mu \mathrm{g} / \mathrm{mL}\right)$ of $S$. rebaudiana leaves cultivated in vitro $(\mathrm{n}=9$, mean $\pm \mathrm{SD})$.

\begin{tabular}{llll}
\hline & $\begin{array}{l}\text { In vitro culture with } \\
\text { kinetin }\end{array}$ & $\begin{array}{l}\text { In vitro culture } \\
\text { without kinetin }\end{array}$ & $\begin{array}{l}\boldsymbol{t} \text {-Students test } \\
\boldsymbol{p} \text {-value }\end{array}$ \\
\hline DPPH scavenging activity & $357 \pm 27$ & $191 \pm 6$ & $<0.001$ \\
Reducing power & $200 \pm 17$ & $70.1 \pm 0.7$ & $<0.001$
\end{tabular}

EC50 values correspond to the sample concentration achieving $50 \%$ of antioxidant activity or 0.5 of absorbance in reducing power assay. Trolox $\mathrm{EC}_{50}$ values: $42 \mu \mathrm{g} / \mathrm{mL}$ (DPPH scavenging activity) and $41 \mu \mathrm{g} / \mathrm{mL}$ (reducing power).

Based on literature available, through comparing in vitro cultures of stevia with the standard ones, it seems that standard (wild, commercial, regional) cultures have higher antioxidant capacity than those presented in in vitro cultured. However, other factors, such as extraction process and solvents used also determine the levels of bioactive molecules in the extracts, and therefore exert a direct influence on final antioxidant activity $[4,13]$. On the other hand, compounds identified in this study can also contribute to the antioxidant activity of samples, namely reducing sugars (e.g., fructose and glucose), tocopherols and phenolic compounds. The latter, and specifically phenolic acids, rarely occur in free forms, being widely common their linkage with other components, such as small organic molecules (glucose and other sugars, quinic, malic and tartaric acids), other secondary metabolites (i.e. terpenes, flavonoids), or some structural plants components (i.e. cellulose, proteins and lignin) [14]. Tocopherols have been recognized as the most important natural antioxidants in foods, being this effect mainly conferred by their prominent action as free radical scavengers and hydrogen donators [15]; $\alpha$-tocopherol is the isoform that confers the highest biological potential. On the other hand, 5-O-caffeoylquinic acid is the most predominant form of chlorogenic acid present in plants, being its antioxidant potential mainly attributed to its double bond conjugated with the catechol structure of phenyl ring. Interestingly, the highest content in chlorogenic acids have been observed in plants in which the most pronounced biological effects are antioxidant, hepatoprotective and antiviral, either reported in vitro, in vivo or in epidemiological studies [16]. Its prominent 
antioxidant activity seems to be related with the ability to decrease reactive oxygen species, through deactivation of a wide range of pro-oxidative enzymes, including lipoxygenase (LOX)-mediated arachidonic acid metabolism inhibition, still remaining many other mechanisms unexplored [17]. Thus, considering these aspects and the results obtained in the present study, the antioxidant activity seems to be more closely related with phenolic compounds and tocopherols contents, since samples showing higher content of these compounds also gave higher antioxidant activity.

\section{Materials and Methods}

\subsection{Micropropagation procedure}

Plant material was obtained from a commercial clone grown in field, previously studied by our research group [4]. 3 different plants were used to perform micropropagation inoculations, starting with 20 tubes in the first inoculation. Leaves for chemical analyses were collected from in vitro plants after 3 subcultures, and after achieving 1 to $1.5 \mathrm{~cm}$ of length. Explants for in vitro culture were harvested in August 2016 and consisted of the whole plant. Afterwards, they were separated in stems and leaves, in order to collect stems with nodes for inoculation (axillar meristems), being leaves discarded. Then, stems with nodes were washed in tap water and the surface sterilized by agitation for 7 minutes in a chlorine 5\% solution, plus 10 drops of tween 80 per $100 \mathrm{~mL}$ of sterilizing solution. After washing in sterilized water, the explants were moved to a ethanol $70 \%$ solution for 5 minutes, washed and inoculated in two different culture media (medium A - MS- Murashige and Skoog, 1962 without hormones and $20 \mathrm{~g} / \mathrm{L}$ of sucrose (J.T. Baker, Deventer, Deutschland) - and medium B - MS with $0.5 \mathrm{mg} / \mathrm{L}$ of kinetin (Merck, Darmstadt, Germany) and $20 \mathrm{~g} / \mathrm{L}$ of sucrose). The culture medium was adjusted to a $\mathrm{pH}$ of 5.7 before autoclaving and placed in round flask tubes (13.5 $x 3 \mathrm{~cm}, 10 \mathrm{~mL}$ ). The culture conditions were $T \min [16-18]^{\circ} \mathrm{C}$, Tmax [24-26] ${ }^{\circ} \mathrm{C}$ with a photoperiod of 16/8 h (light/dark) supplied by light-bulbs Silvana day light (Phillips, Amsterdam, Netherlands). The multiplication rate was determined for each subculture of 2 months in the two-media tested. After 2 months, subculture micropropagated samples (leaves) were immediately frozen $\left(-20{ }^{\circ} \mathrm{C}\right)$ and lyophilized (FreeZone 4.5, Labconco, Kansas City, MO, USA) before analyses.

\subsection{Tocopherols}

Tocopherols were analyzed using an extraction methodology previously described [19], using tocol as an internal standard (IS, racemic tocol $(50 \mathrm{mg} / \mathrm{mL})$, Matreya, Pleasant Gap, PA, USA). A HPLC system (Smartline system 1000; Berlin, Germany) connected to a fluorescence detector (FP-2020; Jasco, Tokyo, Japan), set for excitation at $290 \mathrm{~nm}$ and emission at $330 \mathrm{~nm}$, was used to achieve tocopherols detection. The compounds separation was attained with a Polyamide II normal-phase column $\left(250 \times 4.6 \mathrm{~mm}, 5 \mu \mathrm{m}\right.$; YMC, Kyoto, Japan) working at $35^{\circ} \mathrm{C}$, using a mobile phase consisting of $n$-hexane and ethyl acetate (70:30, v/v, Lab-Scan, Lisbon, Portugal), with a flow rate of $1 \mathrm{~mL} / \mathrm{min}$. Then, tocopherols were identified through chromatographic comparisons with common standards (tocopherol standards, Matreya, Pleasant Gap, PA, USA) using a Clarity 2.4 Software (DataApex, Prague, Czech Republic), and its corresponding quantitation by using IS methodology.

\subsection{Free sugars}

Free sugars content was determined by HPLC (Smartline system 1000; Berlin, Germany) coupled to a refraction index (RI, Knauer Smartline 2300, Berlin, Germany) detector, following an extraction methodology previously described [20], using melezitose (Sigma-Aldrich, St. Louis, MO, USA) as IS. An Eurospher 100-5 $\mathrm{NH}_{2}$ column $(4.6 \times 250 \mathrm{~mm}, 5 \mu \mathrm{m}$, Knauer) was used to perform sugars separation at $35^{\circ} \mathrm{C}$. Mobile phase consisted of a mixture of acetonitrile (Lab-Scan, Lisbon, 
Portugal) and deionized water, 70:30 (v/v), operating at $1 \mathrm{~mL} / \mathrm{min}$. Sugar contents were identified by chromatographic comparisons with commercial standards (fructose, glucose, sucrose, trehalose, and raffinose, Sigma-Aldrich, St. Louis, MO, USA) using a Clarity 2.4 Software and corresponding quantitation by using IS methodology.

\subsection{Phenolic compounds}

Phenolic compounds extraction was accomplished by stirring plant material (leaves, $1 \mathrm{~g}$ ) in 30 $\mathrm{mL}$ of methanol/water $(80: 20, \mathrm{v} / \mathrm{v})$ at $150 \mathrm{rpm}, 25^{\circ} \mathrm{C}$ for $1 \mathrm{~h}$. The extract was filtered (Whatman No. 4 paper) and the final residue was re-extracted with an additional portion $(30 \mathrm{~mL})$ of the methanol/water mixture. After that, combined extracts were evaporated under reduced pressure (rotary evaporator Büchi R-210, Flawil, Switzerland), at $35{ }^{\circ} \mathrm{C}$, and the aqueous phase was lyophilized. Then, the lyophilized extracts were re-dissolved in methanol/water $(80: 20, v / v)$, at a concentration of $5 \mathrm{mg} / \mathrm{mL}$.

Extracts were analyzed using a Hewlett-Packard 1100 chromatograph (Agilent Technologies) with a quaternary pump and a diode array detector (DAD) coupled to an HP Chem Station (rev. A.05.04) data-processing station. A Waters Spherisorb S3 ODS-2 C18 $(4.6 \mathrm{~mm} \times 150 \mathrm{~mm}, 3 \mu \mathrm{m}$; Lisbon, Portugal) column thermostatted at $35{ }^{\circ} \mathrm{C}$ was used for separation. The mobile phase consisted of two solvents: (A) $0.1 \%$ formic acid in water, and (B) acetonitrile, establishing the following elution gradient: 15\% B for $5 \mathrm{~min}, 15 \%$ B to $20 \%$ B over $5 \mathrm{~min}, 20-25 \%$ B over $10 \mathrm{~min}$, 25$35 \%$ B over $10 \mathrm{~min}, 35-50 \%$ B for $10 \mathrm{~min}$, and re-equilibration of the column, using a flow rate of 0.5 $\mathrm{mL} / \mathrm{min}$. Double online detection was carried out in the DAD using $280 \mathrm{~nm}$ and $370 \mathrm{~nm}$ as preferred wavelengths and in a mass spectrometer (MS) connected to HPLC system via the DAD cell outlet [20]. MS detection was performed in an API 3200 Qtrap (Applied Biosystems, Darmstadt, Germany) equipped with an ESI source and a triple quadrupole-ion trap mass analyser that was controlled by the Analyst 5.1 software. Zero grade air served as the nebulizer gas (30 psi) and turbo gas for solvent drying (400 $\left.{ }^{\circ} \mathrm{C}, 40 \mathrm{psi}\right)$. Nitrogen served as the curtain $(20 \mathrm{psi})$ and collision gas (medium). The quadrupols were set at unit resolution. The ion spray voltage was set at $-4500 \mathrm{~V}$ in the negative mode and spectra were recorded between $\mathrm{m} / \mathrm{z} 100$ and 1500. The MS detector was programed for recording in two consecutive modes: enhanced MS (EMS) and enhanced product ion (EPI) analysis. EMS was employed to show full scan spectra, so as to obtain an overview of all of the ions in sample. Settings used were: declustering potential (DP) $-450 \mathrm{~V}$, entrance potential (EP) $-6 \mathrm{~V}$, collision energy (CE)-10 V. EPI mode was performed in order to obtain the fragmentation pattern of the parent ion(s) in the previous scan using the following parameters: DP $-50 \mathrm{~V}, \mathrm{EP}-6 \mathrm{~V}, \mathrm{CE}-25 \mathrm{~V}$, and collision energy spread (CES) $0 \mathrm{~V}$.

Phenolic compounds identification was fulfilled by comparison with standard compounds or tentatively assigned by comparing their UV and mass spectra with data reported in literature. Quantitative analysis was performed by comparing peak areas recorded at $330 \mathrm{~nm}$ with the calibration curve obtained for 5-O-caffeoylquinic acid ( $\mathrm{y}=168823 \mathrm{x}-161172 ; R^{2}=0.999$; Extrasynthèse, Genay, France). The results were expressed in $\mathrm{mg} / \mathrm{g}$ of extract.

\subsection{Evaluation of antioxidant activity}

To perform this experiment, the lyophilized extracts described above were re-dissolved in methanol/water (80:20, v/v), at a final concentration of $5 \mathrm{mg} / \mathrm{mL}$, being further diluted into different concentrations in order to be submitted to distinct in vitro assays. The antioxidant activity was evaluated using the 2,2-diphenyl-1-picrylhydrazyl (DPPH) radical-scavenging activity and reducing power assays.

DPPH radical-scavenging activity was evaluated by using an ELX800 microplate reader (Bio-Tek Instruments, Inc; Winooski, VT, USA). Various concentrations of the extracts $(30 \mu \mathrm{L})$ were mixed with a methanol solution containing DPPH radicals $\left(6 \times 10^{-5} \mathrm{mM}, 270 \mu \mathrm{L}\right.$, (Alfa Aesar, Ward Hill, MA, USA) in a 96-well plate and then were left to stand for $60 \mathrm{~min}$ in the dark. The reduction of 
the DPPH radical was determined by measuring the absorption at $515 \mathrm{~nm}$ and calculated as a percentage of DPPH discoloration using the formula: [(ADPPH-AS)/ADPPH] $\times 100$, where AS is the absorbance of the solution containing the sample at $515 \mathrm{~nm}$, and ADPPH is the absorbance of the DPPH solution.

Reducing power was evaluated by the capacity to convert $\mathrm{Fe}^{3+}$ to $\mathrm{Fe}^{2+}$, measuring the absorbance at $690 \mathrm{~nm}$ in the microplate reader mentioned above. Various concentrations of the extracts $(500 \mu \mathrm{L})$ were mixed with sodium phosphate buffer ( $\mathrm{pH} 6.6,200 \mathrm{mM}, 500 \mu \mathrm{L})$ and potassium ferricyanide $(1 \% \mathrm{w} / \mathrm{v}, 500 \mu \mathrm{L})$ in an Eppendorf $(2 \mathrm{~mL})$ and incubated at $50{ }^{\circ} \mathrm{C}$ for $20 \mathrm{~min}$. Trichloroacetic acid $(10 \%, 500 \mu \mathrm{L})$ was added and then the upper layer $(800 \mu \mathrm{L})$ was mixed with deionized water $(800 \mu \mathrm{L})$ and ferric chloride $(0.1 \%, 160 \mu \mathrm{L})$ in a 48 -well plate; the absorbance was further measured at $690 \mathrm{~nm}$.

The results were expressed in $\mathrm{EC}_{50}$ values (sample concentration providing $50 \%$ of antioxidant activity or 0.5 of absorbance in the reducing power assay). Trolox (6-hydroxy-2,5,7,8tetramethylchroman-2-carboxylic acid, Sigma-Aldrich, St. Louis, MO, USA) was used as standard [20].

\subsection{Statistical analysis}

The assays were carried out in triplicate being three samples used for each preparation, and results were expressed as mean values \pm standard deviation (SD). Data were analyzed using Student's t-test with $\alpha=0.05$ (SPSS v. 23.0 program, IBM, Armonk, NY, USA).

\section{Conclusions}

Stevia rebaudiana has received an increasing demand for multiple purposes, being clearly evident those related with culinary, agroindustry (as sweetener) and pharmacological purposes. All these aspects are closely determined by their richness in bioactive compounds, which in face to this intensive demand may become scarce, also compromising their upcoming applications.

In this study, stevia was cultured with and without kinetin in order to evaluate the protective and/or strengthening effect of this phytoregulator in phenolic compounds, free sugars and tocopherols contents, and antioxidant activity. However, kinetin did not provide an incremental effect neither on stevia antioxidant potential nor on the analyzed compounds, except for two chlorogenic acids (i.e., 3-O-caffeoylquinic and 4-O-caffeoylquinic acids) and sugar contents, thus it providing a higher multiplication rate. Further studies should be performed to determine if kinetin at different concentrations could increase stevia antioxidants, as also to test other plant growth phytoregulators and even stress conditions. This assessment will be of utmost importance, as micropropagation technique is an efficient process to obtain plant material for industrial exploitation. The in vitro culture allows a continuously biomass production regardless of the edaphoclimatic conditions of the region, which makes it an added value for studies without climatic or space constraints.

Acknowledgments: The authors are grateful to the Foundation for Science and Technology (FCT) of Portugal and FEDER under Programme PT2020 for financial support to CIMO (UID/AGR/00690/2013), REQUIMTE/LAQV (UID/QUI/50006/2013 - POCI/01/0145/FERDER/007265) and L. Barros research contract. The authors are grateful to FEDER-Interreg España-Portugal programme for financial support through the project 0377_Iberphenol_6_E. The authors are also grateful to Hugo Goes, from the Polytechnic Institute of Bragança, for the in vitro culture maintenance of the studied species. 
(1) Interreg

Conflicts of Interest: “The authors declare no conflict of interest."

\section{References}

1. Dias, M. I.; Sousa, M. J.; Alves, R. C.; Ferreira, I. C. F. R. Exploring plant tissue culture to improve the production of phenolic compounds: A review. Ind. Crops Prod. 2016, 82, 9-22.

2. Wang, J.; Li, J.; Li, J.; Li, J.; Liu, S.; Huang, L.; Gao, W. Production of active compounds in medicinal plants: From plant tissue culture to biosynthesis. Chinese Herb. Med. 2017, 9, 115-125.

3. Eser, A.; Aydemir, T. The effect of kinetin on wheat seedlings exposed to boron. Plant Physiol. Biochem. 2016, $108,158-164$.

4. Barroso, M.; Barros, L.; Rodrigues, M. Â.; Sousa, M. J.; Santos-Buelga, C.; Ferreira, I. C. F. R. Stevia rebaudiana Bertoni cultivated in Portugal: A prospective study of its antioxidant potential in different conservation conditions. Ind. Crops Prod. 2016, 90, 49-55.

5. Yu, H.; Yang, G.; Sato, M.; Yamaguchi, T.; Nakano, T.; Xi, Y. Antioxidant activities of aqueous extract from Stevia rebaudiana stem waste to inhibit fish oil oxidation and identification of its phenolic compounds. Food Chem. 2017, 232, 379-386.

6. Ghanta, S.; Banerjee, A.; Poddar, A.; Chattopadhyay, S. Oxidative DNA damage preventive activity and antioxidant potential of Stevia rebaudiana (Bertoni) Bertoni, a natural sweetener. J. Agric. Food Chem. 2007, 55, 10962-10967.

7. Werner, T.; Motyka, V.; Strnad, M.; Schmülling, T. Regulation of plant growth by cytokinin. Proc. Natl. Acad. Sci. U. S. A. 2001, 98, 10487-10492.

8. Tounekti, T.; Hernández, I.; Müller, M.; Khemira, H.; Munné-Bosch, S. Kinetin applications alleviate salt stress and improve the antioxidant composition of leaf extracts in Salvia officinalis. Plant Physiol. Biochem. 2011, 49, 1165-1176.

9. Barroso, M. R.; Martins, N.; Barros, L.; Antonio, A. L.; Rodrigues, M. Â.; Sousa, M. J.; Santos-Buelga, C.; Ferreira, I. C. F. R. Assessment of the nitrogen fertilization effect on bioactive compounds of frozen fresh and dried samples of Stevia rebaudiana Bertoni. Food Chem. 2018, 243.

10. Ahmed, A. M. A.; Khalid, K. A. Influence of kinetin on growth, chemical constituents and nutrient content of black cumin (Nigella sativa L.). Bangladesh J. Bot. 2017, 46, 783-787.

11. Radić, S.; Vujčić, V.; Glogoški, M.; Radić-Stojković, M. Influence of ph and plant growth regulators on secondary metabolite production and antioxidant activity of Stevia rebaudiana (Bert). Period. Biol. 2016, 118, 919.

12. Khalil, S. A.; Kamal, N.; Sajid, M.; Ahmad, N.; Zamir, R.; Ahmad, N.; Ali, S. Synergism of polyamines and plant growth regulators enhanced morphogenesis, stevioside content, and production of commercially important natural antioxidants in Stevia rebaudiana Bert. Vitr. Cell. Dev. Biol. - Plant 2016, 52, 174-184.

13. Yildiz-Ozturk, E.; Nalbantsoy, A.; Tag, O.; Yesil-Celiktas, O. A comparative study on extraction processes of Stevia rebaudiana leaves with emphasis on antioxidant, cytotoxic and nitric oxide inhibition activities. Ind. Crops Prod. 2015, 77, 961-971.

14. Ferreira, I. C. F. R.; Martins, N.; Barros, L. Phenolic compounds and its bioavailability: in vitro bioactive compounds or health promoters? Adv. Food Nutr. Res. 2017, 82, 1-44. 
15. Jabeur, I.; Tobaldini, F.; Martins, N.; Barros, L.; Martins, I.; Calhelha, R. C.; Henriques, M.; Silva, S.; Achour, L.; Santos-Buelga, C.; Ferreira, I. C. F. R. Bioactive properties and functional constituents of Hypericum androsaemum L.: A focus on the phenolic profile. Food Res. Int. 2016.

16. Marques, V.; Farah, A. Chlorogenic acids and related compounds in medicinal plants and infusions. Food Chem. 2009, 113, 1370-1376.

17. Gawlik-Dziki, U.; Świeca, M.; Dziki, D.; Kowalska, I.; Pecio, Ł.; Durak, A.; Seczyk, Ł. Lipoxygenase inhibitors and antioxidants from green coffee-mechanism of action in the light of potential bioaccessibility. Food Res. Int. 2014, 61, 48-55.

18. Murashige, T.; Skoog, F. A revised medium for rapid growth and bio assays with tobacco tissue cultures. Physiol. Plant. 1962, 13, 473-497.

19. Fernandes, Â.; Barreira, J. C. M.; Antonio, A. L.; Santos, P. M. P.; Martins, A.; Oliveira, M. B. P. P.; Ferreira, I. C. F. R. Study of chemical changes and antioxidant activity variation induced by gamma-irradiation on wild mushrooms: Comparative study through principal component analysis. Food Res. Int. 2013, 54, 18-25.

20. Barros, L.; Pereira, E.; Calhelha, R. C.; Dueñas, M.; Carvalho, A. M.; Santos-Buelga, C.; Ferreira, I. C. F. R. Bioactivity and chemical characterization in hydrophilic and lipophilic compounds of Chenopodium ambrosioides L. J. Funct. Foods 2013, 5, 1732-1740.

Sample Availability: Samples are available from the authors.

(C) 2018 by the authors. Submitted for possible open access publication under the terms and conditions of the Creative Commons Attribution (CC BY) license (http://creativecommons.org/licenses/by/4.0/). 